\title{
ANÁLISE DO PROCESSO DE ATENDIMENTO A ITENS NAO CONFORMES NO CAMPO
}

Dissertação apresentada à Escola de Engenharia de São Carlos da Universidade de São Paulo, como parte dos requisitos para obtenção do título de Mestre em Engenharia Mecânica.

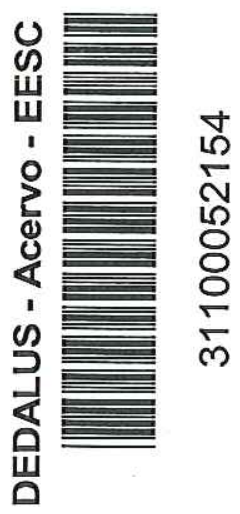

ORIENTADOR: Prof. Dr. Arthur José Vieira Porto

São Carlos

2004 
Salvador, Carlos Cesar
S182a Análise o processo de atendimento a itens não conformes no campo / Carlos Cesar Salvador. -- São Carlos, 2004 .

Dissertação (Mestrado) -- Escola de Engenharia de São Carlos-Universidade de São Paulo, 2004.

Área: Engenharia Mecânica.

Orientador: Prof. Dr. Arthur José Vieira porto.

1. Confiabilidade. 2. Teste de campo. I. Título. 
Candidato: Engenheiro CARLOS CESAR SALVADOR

Dissertação defendida e julgada em 20-12-2004 perante a Comissão Julgadora:

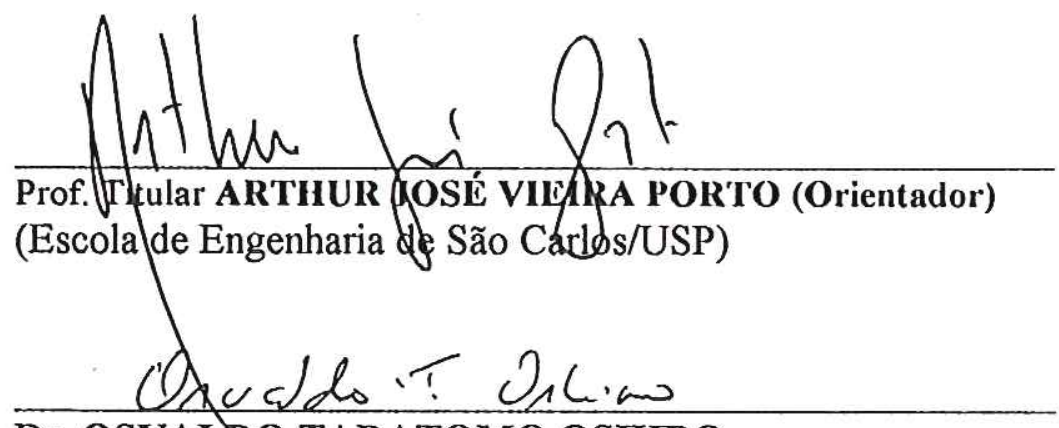

Dr. OSVALDO TADATOMO OSHIRO

(Empresa Brasileira de Pesquisa Agropecuária/EMBRAPA)

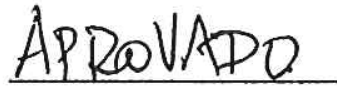

APNOUADO

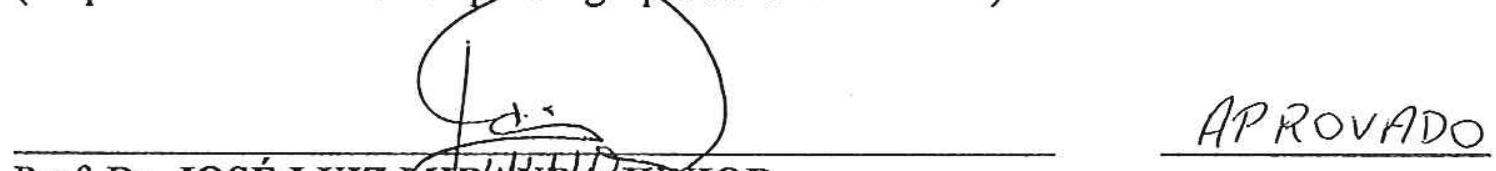

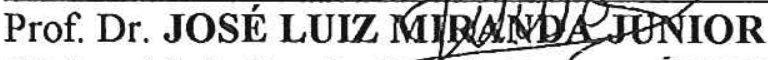

(Universidade Camilo Castelo Branco - UNICASTELO)

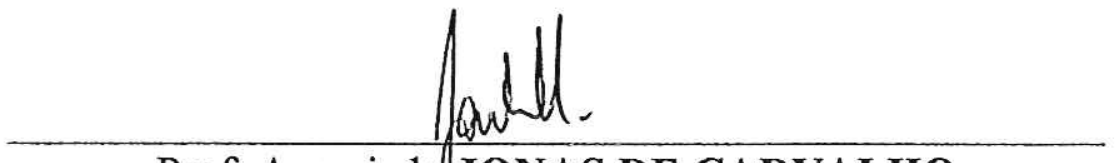

Prof. Associado JONAS DE CARVALHO

Coordenador do Programa de Pós-Graduação em Engenharia Mecânica

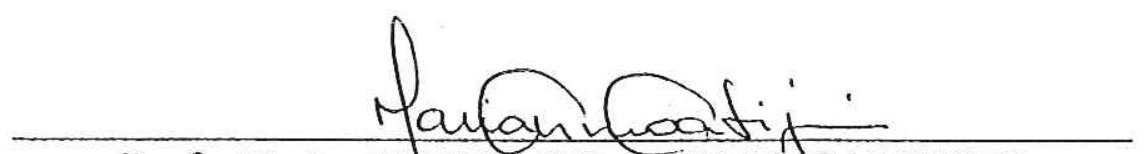

Profa. Titular MARIA DO CARMOJCALIJURI

Presidente da Comissão de Pós-Graduação 
À minha esposa Sandra e as minhas filhas Laís e Gabriela e aos meus pais Eduardo e Oliva, com muito amor e carinho. 


\section{Agradecimentos:}

A Deus, que me deu a vida, a inspiração e a luz para encontrar o meu caminho.

Ao Professor Dr Arthur José Vieira Porto, pela oportunidade, pela orientação acadêmica e de pesquisa, além da amizade desde o inicio deste trabalho.

A Caterpillar Brasil, em especial aos Eng. Vander Freitas e José Carlos Santos, por ter me proporcionado o tempo e as condições necessárias para conciliar as atividades profissionais e com as atividades deste trabalho.

A Sotreq e seus funcionários, que direta ou indiretamente, contribuíram com informações para a realização deste trabalho.

A todos os professores e funcionários do Departamento de Engenharia Mecânica da EESC/USP, pela colaboração.

A minha esposa Sandra e as minhas filhas Laís e Gabriela, por abrirem mão dos momentos de lazer e divertimento em pró do apoio e incentivo a realização deste trabalho.

Aos meus pais Eduardo e Oliva, pela educação, motivação e incentivo em busca de um futuro melhor para seus filhos.

Aos meus irmãos Elizabeth, Wilson e Iria e suas respectivas famílias, pelo apoio e incentivo na realização deste trabalho. 


\section{SUMÁRIO}

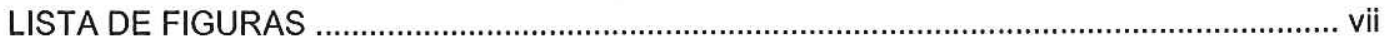

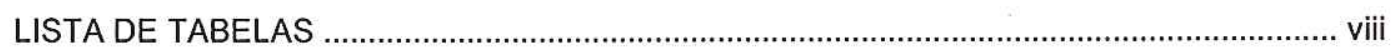

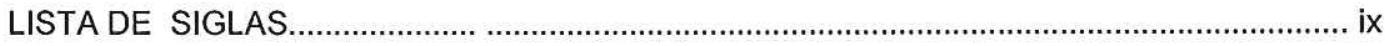

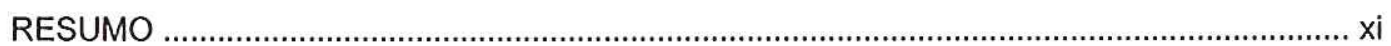

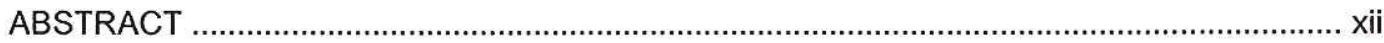

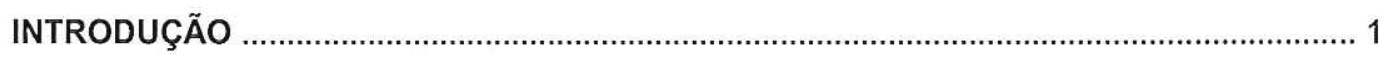

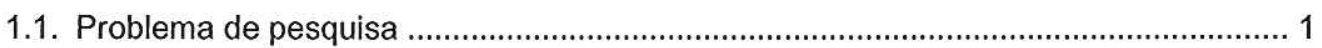

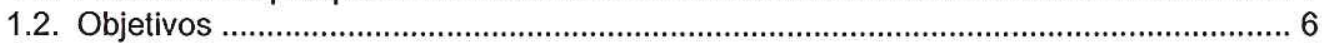

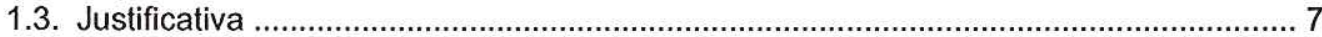

1.4. Problema de Pesquisa em Forma de Perguntas ..................................................... 8

1.5. Hipóteses ................................................................................................................ 9

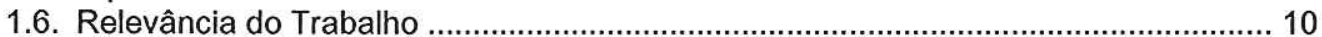

1.7. Limitação do tema de pesquisa ............................................................................... 10

1.8. Estrutura do Trabalho ..................................................................................................... 11

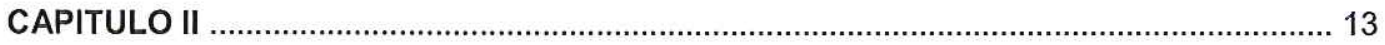

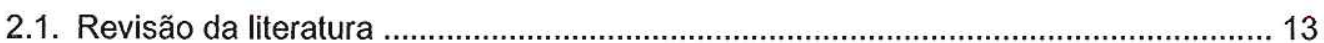

2.2. Definição de Confiabilidade ................................................................................ 14

2.3. Classificação e definição de falha ................................................................................ 19

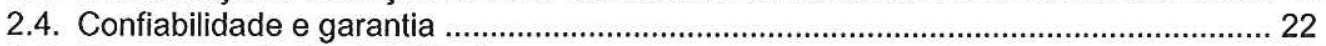

2.5. Engenharia de Confiabilidade ................................................................................. 26

2.6. Normas de Confiabilidade e manutenabilidade ........................................................ 27

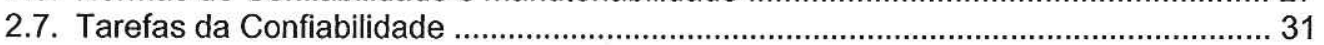

2.7.1.Tarefas da Confiabilidade durante a fase de projeto ........................................ 32

2.7.1.1. Previsão da Confiabilidade ............................................................... 35

2.7.1.2. Análise do Modo e Efeito da Falha ............................................... 37

2.7.1.3. Árvore de Falha ............................................................................. 43

2.7.2. Tarefa da Confiabilidade durante a fase de teste ............................................. 46

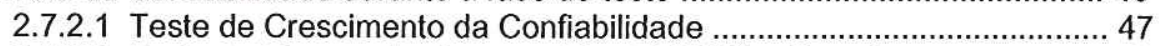

2.7.2.2 Teste de triagem de stress ambiental (ESS) e Burn-in ..................... 52

2.8. Previsão das falhas do produto .............................................................................. 53

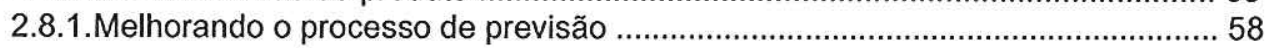

2.9. A importância dos dados de Confiabilidade de campo ............................................ 59

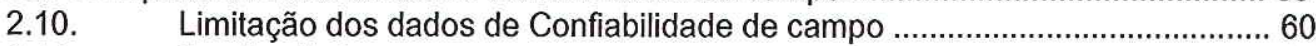

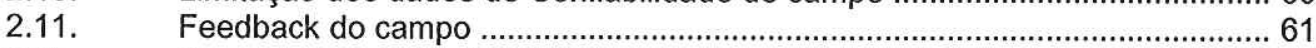

2.12. Quais dados de Confiabilidade de campo são importantes para a Empresa .. 63

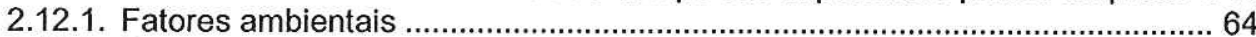

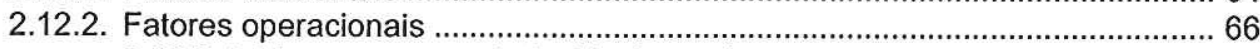

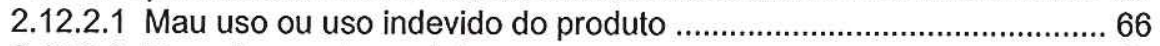

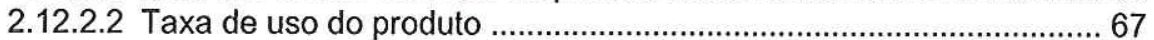

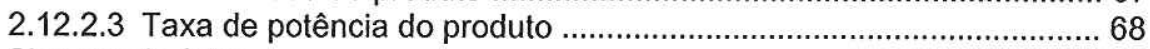

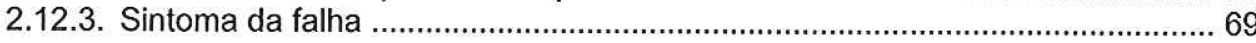


2.12.4. Diagnóstico observado durante o reparo .................................................... 70

2.12.5. Índice de Confiabilidade.....

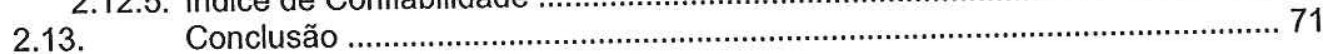

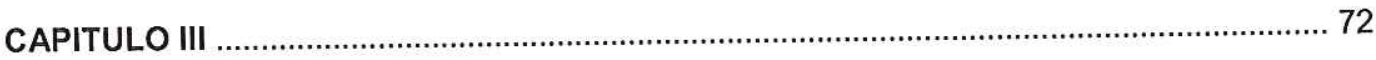

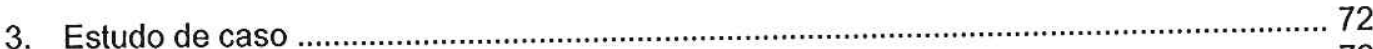

3.1. Introdução ..................

3.2. Justificativa da escolha

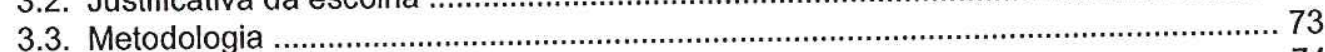

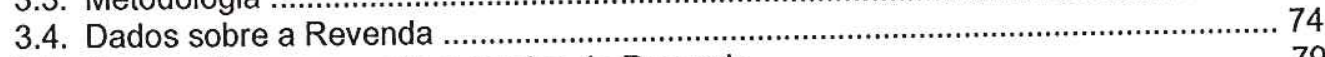

3.5. Como a Empresa avalia o serviço da Revenda ....................................................... 79

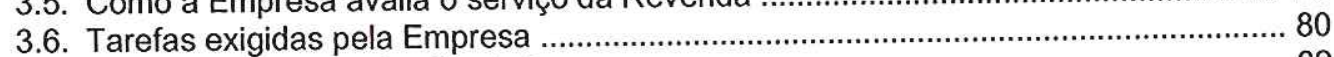

3.7. Como é realizado o feedback do campo .............................................................. 82

3.8. Dados obtidos através do Programa Parceiro na Qualidade (PIQ) ............................ 84

3.9. Dados de falhas coletados pela Revenda ............................................................... 86

3.10. A dificuldade de se obter dados sobre os fatores operacionais ..................... 88

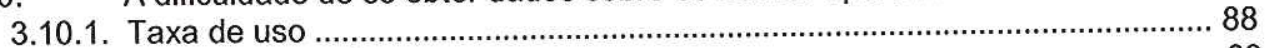

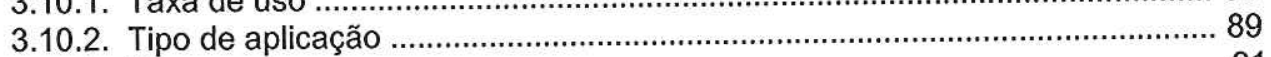

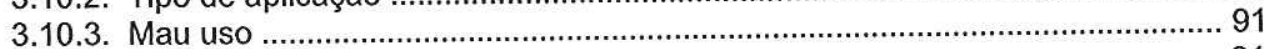

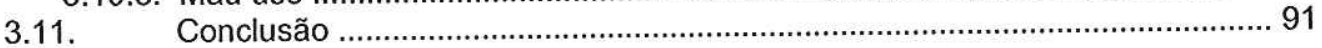

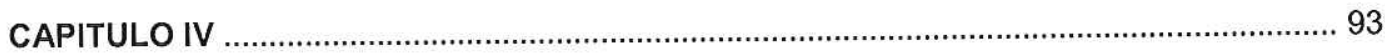

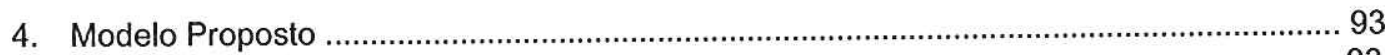

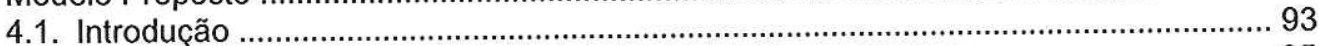

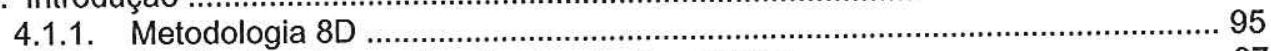

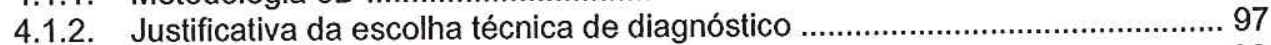

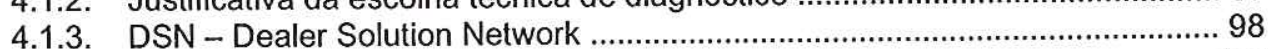

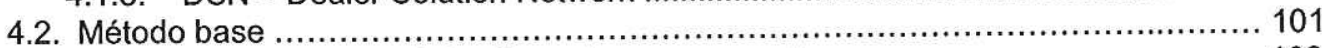

4.2.1. Quando uma solicitação pode ser encerrada ............................................ 102

4.3. Modelo proposto ….......................................................................................... 103

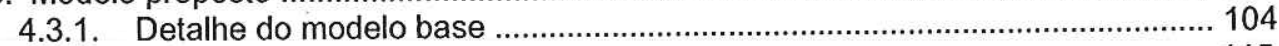

4.4. Proposta de melhoria no método .......................................................................... 115

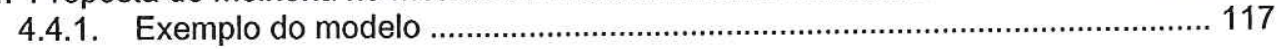

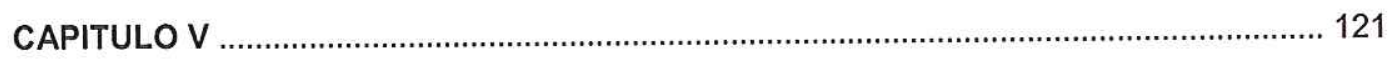

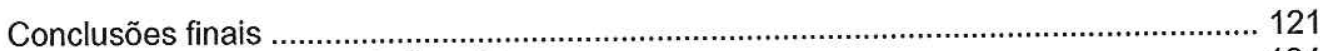

Recomendações para trabalhos futuros ................................................................... 124

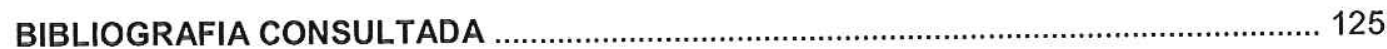




\section{ÍNDICE DE FIGURAS}

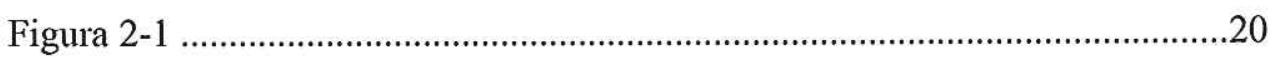

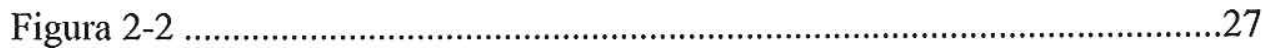

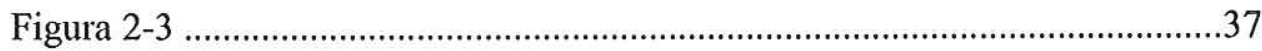

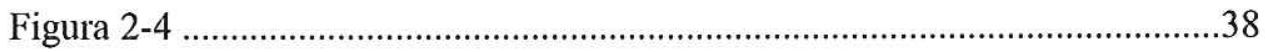

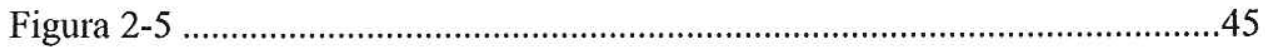

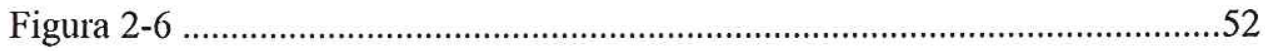

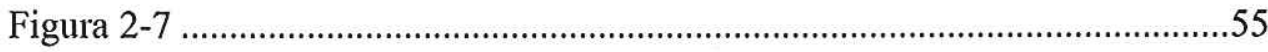

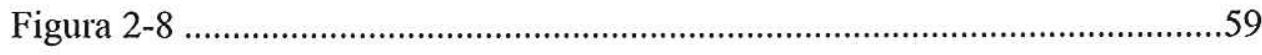

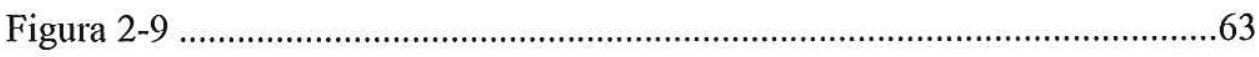

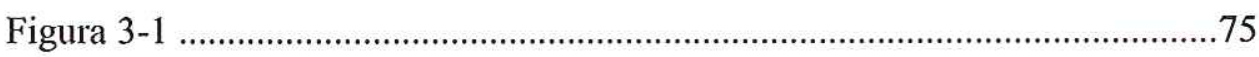

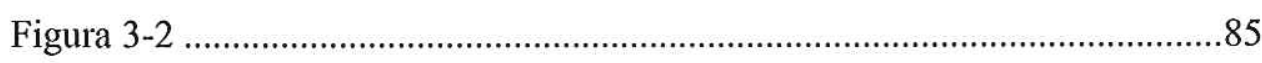

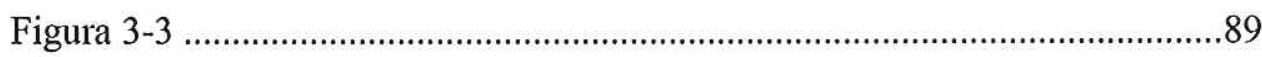

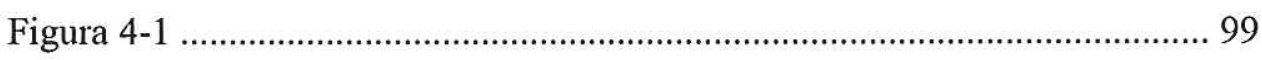

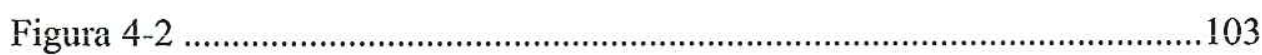

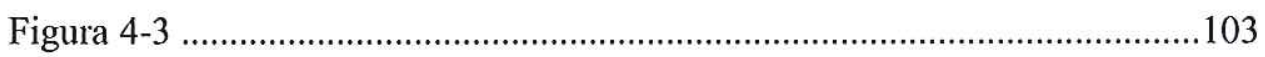

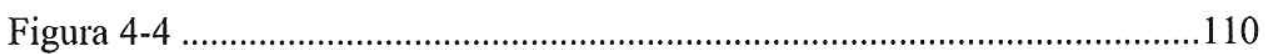

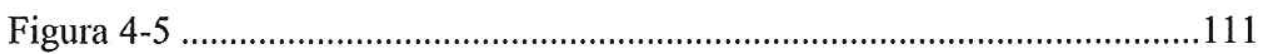

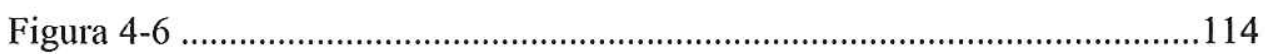

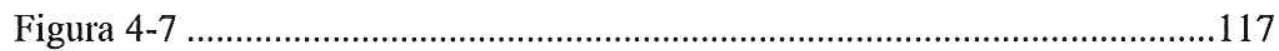

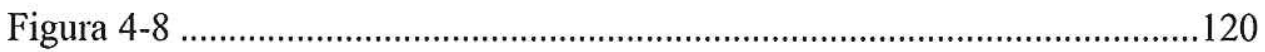




\section{ÍNDICE DE TABELAS}

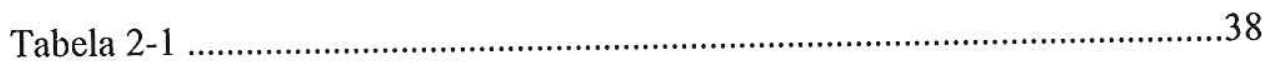

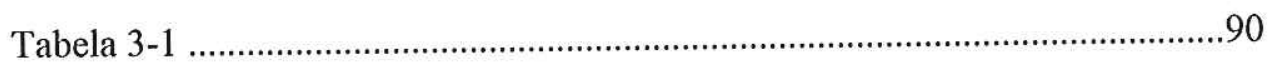

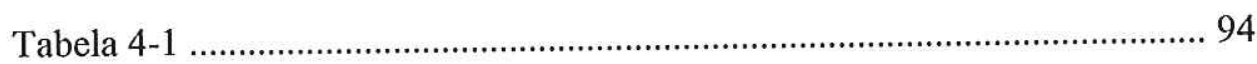

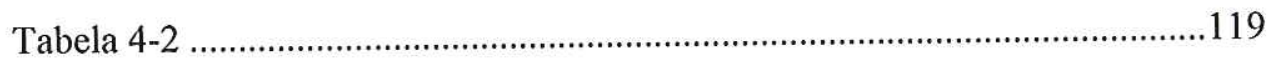




\section{ÍNDICE DE SIGLAS}

A

ABNT - Associação Brasileira de Normas Técnicas

C

CPPD - Concurrent Project and Process Development (Desenvolvimento do projeto e processo simultaneamente)

$\mathrm{CPI}$ - Continuous Product Improvement (Melhoria contínua do produto)

D

DARPA - Defense Advanced Research Project Agency

DFMEA - Design Failure Modes and Effects Analysis (análise do modo e efeito da falha no desenho)

DMAMC - Definir / Medir / Analisar / Melhorar / Controlar

DMEDI - Definir / Medir / Explorar / Desenvolver / Implementar

DSN - Dealer Solution Network (Rede de comunicação entre Revenda e Empresa)

DRF - Dealer Repair Frequency (Frequencia de reparo pela Revenda)

E

EPP - Plano de Proteção do Equipamento

ERA - Emergencial Repair Action (Ação de reparo emergencial)

ESS - Environmental Stress Screening (triagem de stress ambiental)

$\mathrm{F}$

FMEA - Failure Mode and Effects Analysis (análise do modo e efeito da falha)

FMECA - Failure Mode, effects and critical analysis (análise critica do modo e efeito da falha) 
FTA - Fault Tree Analisys

I

ICA - Ínterim Correct Action (Ação de correção temporária)

IEC - International Electrotechnical Commission

ISO - International Standardization Organization (Organização Internacional para Padronização)

M

MIL-HDBK - USA Military Standard - handbook

MTBF - Mean Time Between Failure (tempo médio entre falhas)

MTTF - Mean Time to Failure (tempo médio até ocorrer a primeira falha)

MTTR - Mean Time to Repair (tempo médio até efetuar o reparo)

$\mathrm{P}$

PCA - Permanent Correct Action (Ação de correção permanente)

PDCA - Plan, Do, Check, Action (Planejar, executar, verificar, atuar)

PFMEA - Process Failure Modes and Effects Analysis

PIQ - Partners In Quality (Parceiros em qualidade)

PMP - Programa de Manutenção Preventiva

$S$

SED - Serviço Especializado de Diagnose

SIMS - Service Information Management System

S.O.S. - Schedule Oil Sampling (Sistema de Análise de Óleo)

Sotreq - Sociedade de Tratores e Equipamentos S. A 


\section{RESUMO}

A Confiabilidade do produto é um dos principais atributos da sua qualidade, porém a melhoria continua desta Confiabilidade é um objetivo inalcançável para as Empresas, principalmente após o processo de globalização, no qual as Empresas locais não mais têm como competidores apenas as Empresas regionais ou nacionais, mas também as outras Empresas mundiais. Outro fator importante, para o estabelecimento da Confiabilidade, é o Cliente que têm aumentado as suas exigências num processo continuo, em que os aspectos de conformidade às especificações do projeto estão se tornando critério de compra. Este trabalho, através de um estudo de caso, apresenta a análise de um processo de atendimento a itens não conformes e propõe melhorias neste processo, visando agilizar a solução de problemas de campo. Para isso será avaliada a Confiabilidade da Empresa, desde a comunicação do Cliente, passando pelo revendedor e da própria Empresa, até a metodologia utilizada para a análise das falhas de campo dos produtos existentes. Os registros e informações da área de suporte e serviços, serão fundamentais para a introdução de melhorias para o procedimento atualmente em uso pela Empresa.

Palavras-chave: Confiabilidade, Teste de Campo 


\section{ABSTRACT}

The reliability of a product is one of the main attributes of its quality, however continuous improvement of its reliability is a never-ending journey for companies, especially those with global processes, as they must compete with other regional, national and global companies. Another important factor in determining the reliability of a product is the understanding of the critical customer requirements. Due to market globalization, consumers now have access to a greater variety of products and are better able to make comparisons between similar items. This ability drives consumers to constantly change or refine their critical requirements that ultimately influence their purchasing decisions. This case study presents an analysis of a process for monitoring product non-conformances and proposes process improvements aimed at speeding up the solution to field problems. To do this, company reliability will be analyzed in terms of the path of communication of product problems from the customer to the dealer, the dealer to the factory and from the factory to the methodology used to analyze field failures. Information from the Product Support and Services area will be fundamental to the introduction of improvements to the current field failure processes.

Key-words: Reliability, Field Test 


\section{INTRODUÇÃO}

\subsection{Problema de pesquisa}

A busca incessante e alucinante da competitividade, seja ela enraizada no instinto de sobrevivência ou associada às exigências cada vez maiores do mercado, principalmente no que diz respeito ao menor preço com maior qualidade, está fazendo com que as Empresas superem essas pressões através das inovações, das reduções do ciclo de desenvolvimento do produto e do controle de seu custo, além da melhoria contínua da qualidade de seu produto.

A competitividade entre as organizações não pode ser restrita aos seus aspectos regionais ou de País. A globalização dos negócios induz, inevitavelmente, à necessidade de algumas Empresas competirem em escala global. Levando-se em conta os fatores externos de competitividade como custo, qualidade, flexibilidade e tempo. Surge a necessidade de que organizações tenham padrões de desempenho compatíveis com a necessidade de competitividade, sejam elas locais, regionais, nacionais ou globais; os padrões de competitividade mundial a serem atingidos provocam alterações dramáticas nas práticas atuais de muitas Empresas de manufatura, particularmente no que se refere ao aumento do uso de ativos, qualidade superior, custos mais baixos, maior produtividade e tempos totais de manufatura (lead times) reduzidos. (Agostinho, 2002).

O desenvolvimento indústrial sempre deu ênfase aos processos indústriais internos. Isso explica sua atual posição de destaque, evidenciado 
pelas diversas filosofias, metodologias, sistemas organizacionais e ferramentas, que têm sido desenvolvidas e colocadas em prática, com excelentes resultados na otimização dos processos de fabricação. Assim, muitas das práticas Empresariais hoje estão focadas sobre a base das inovações, da criatividade e dos esforços; objetivando a redução de tempos e de esforços, economia de materiais, redução do custo da não conformidade (interna ou externa), utilização de manufatura virtual, trabalhos em equipes multifuncionais, engenharia simultânea, etc., os quais se traduzem, ao final, como redução de custos e/ou redução do ciclo de utilização ou de desenvolvimento do produto. Segundo Juran, um produto é um bem ou um serviço (Juran, 1991).

Estas práticas definem ótimos produtos do ponto de vista técnicofinanceiro, porém com o constante aumento das exigências pelo mercado, essas melhorias não têm sido suficientes para o sucesso de um produto, a menos que incorpore as necessidades e desejos dos consumidores finais, que são, definitivamente, os elementos portadores da qualidade e necessidade do Cliente. Essas sim, são as variáveis fortes suficientes para definir o futuro de uma Empresa. O Cliente é definido como qualquer pessoa que seja impactada pelo produto ou processo. Os Clientes podem ser externos ou internos (Juran, 1991).

Os movimentos de aumento da concorrência, rápidas mudanças tecnológicas, diminuição do ciclo de vida dos produtos e maior exigência por parte dos consumidores exigem das Empresas agilidade, produtividade e alta qualidade que dependem necessariamente da eficiência e eficácia da Empresa neste processo (Amaral \& Rozenfel, 2001).

Outro fator fundamental, em termos competitivos, é o tempo: se por um lado as novas metodologias de manufatura têm permitido reduzir os tempos de fabricação, por outro não têm tido sucesso na redução do seu tempo total de desenvolvimento. Além disso, os produtos têm tido seus ciclos de vida diminuídos, resultando que, em alguns casos, o desenvolvimento de um novo 
produto ou a sua atualização, não tem sido feitos adequadamente, com isso as não-conformidades acabam não sendo solucionadas antes do produto entrar em produção, e como conseqüência o Cliente acaba sendo o grande prejudicado.

As ferramentas de manufatura virtual podem ser usadas durante o ciclo de desenvolvimento simultâneo do produto e processo, com o intuito de acelerar a introdução de novos produtos e otimizar a produção, visto que, é um ambiente integrado e sintético da manufatura que faz uso de modelos computacionais e simulações de processos de manufatura para auxiliar no desenvolvimento e produção de produto (Ravelli, 2003).

A diminuição constante do ciclo de vida dos produtos tem sido um objetivo constantemente agressivo, de tal forma que toda vez que este objetivo é atingido, um novo e mais desafiador é estabelecido. Isso tem forçado as Empresas a melhorarem seus processos de desenvolvimento de produtos cada vez mais. Um dos instrumentos utilizados é o Ciclo de Deming ou Ciclo da Qualidade ou mais conhecido como PDCA, sendo uma de suas características um processo permanente de busca e de aprimoramento dos padrões de qualidade, (Abreu, 2001):

$P$ - definir o objetivo desejado, os passos e os meios para atingi-lo.

D - executar os passos conforme planejado

$\mathrm{C}$ - gerenciar (acompanhar e controlar) as atividades e os resultados

A - agir, corrigindo e aperfeiçoando, ao longo e ao final do processo

O ciclo PDCA é um método gerencial de tomada de decisões para garantir o alcance das metas necessárias à sobrevivência de uma organização. O PDCA empregado para o alcance das metas para manter o processo atual é 
denominado CICLO SDCA, e o PDCA utilizado para o alcance das metas para melhorar é denominado Método de Solução de Problemas (Werkema, 1996).

Para o PDCA, a Engenharia Simultânea é uma aliada muito importante tendo por objetivo reduzir o prazo de desenvolvimento de produtos, visto que as atividades das diferentes áreas da Empresa deixaram de seguir a forma seqüencial, em que obrigatoriamente a atividade sucessora só iniciaria com o término da antecessora.

O estudo realizado pelo DARPA (Defense Advanced Research Project Agency) definiu Engenharia Simultânea da seguinte forma: "Engenharia Simultânea é uma abordagem sistemática para o desenvolvimento integrado e paralelo do projeto de um produto e os processos relacionados, incluindo manufatura e suporte. Essa abordagem procura fazer com que as pessoas envolvidas no desenvolvimento considerem, desde o início, todos os elementos do ciclo de vida do produto, da concepção ao descarte, incluindo qualidade, custo, prazos e requisitos dos Clientes." (Zancul, 1999).

Para o mercado atual, a Qualidade é um dos requisitos já incorporado ao produto e não algo que ele tenha que pagar por isso. Uma das estratégias atuais de diversas Empresas, para ganhar uma fatia maior do mercado ou mesmo para manter-se nele, é ampliar o prazo de garantia de seus produtos e, para que isso ocorra, é necessário que elas conheçam o nível de Confiabilidade do seu produto. De posse do nível de Confiabilidade do produto, a Empresa poderá estabelecer projetos de melhoria contínua de forma a minimizar / eliminar o custo de reparo junto aos seus Clientes.

A Confiabilidade é um atributo que deve ser considerada em todas as etapas do ciclo de vida do produto, desde a etapa das necessidades do mercado, planejamento do produto, processo de projeto, produção, consumo e descarte. (Dias, 1999). 
A Empresa que estará sendo analisada, avalia a Confiabilidade de seus produtos em todas as etapas do ciclo de desenvolvimento do produto. Somente como exemplo, será mencionada como são coletadas as informações em duas destas etapas:

- Durante a fase de desenvolvimento do produto para dados pilotos, os dados são coletados pelo (a):

- Cliente em base diária;

- Revenda em base semanal;

- Empresa em base mensal.

Todas as informações coletadas nesta fase são avaliadas, registradas e endereçadas. Sendo assim, toda e qualquer não-conformidade é solucionada e validada durante a fase de desenvolvimento, de forma a evitar que a mesma repita, quando o produto estiver em produção.

- Após o produto estar em produção, os dados são coletados pela:

- Revenda a cada intervenção e registrados em sistema informatizados;

- Empresa, mensalmente, através de procedimentos formais, classifica todas as falhas por incidência e custo de garantia.

Mesmo sendo a Confiabilidade um atributo que deve ser considerado em todas as etapas do ciclo de desenvolvimento do produto, ela não tem evitado que falhas cheguem junto ao Cliente final. O motivo é a dificuldade de prevêlas, seja devido às variáveis que as estimulam ou mesmo ao custo envolvido em prevê-las. Sendo assim, a Revenda é um parceiro fundamental para 
monitorar a saúde do produto, dando o apoio necessário ao Cliente para que seu equipamento esteja a maior parte do tempo disponível para uso. Outra atribuição importante da Revenda é informar clara e detalhadamente à Empresa, através de procedimentos formais, todas as falhas ocorridas com o produto, a fim de que uma ação de correção seja implementada nos produtos que já estão no campo, bem como nos produtos a serem fabricados.

\subsection{Objetivos}

Portanto, visando a minimizar ou eliminar as não-conformidades reportadas pela Revenda e/ou Cliente (campo), o objetivo deste trabalho é estudar o processo de atendimento a itens não conformes e propor uma melhoria no modelo para agilizar a solução de problemas de campo.

Espera-se, ao atingir este objetivo, também responder às seguintes questões:

- Qual a dificuldade de coletar determinados dados de campo ?

- Como é realizada a comunicação entre o Cliente, Revenda e a Empresa?

- Qual é a qualidade do processo de comunicação entre as 3 partes envolvidas?

- Como os dados de campo são tratados pela Empresa e quanto tempo leva para um problema ser solucionado?

Para cada fase do processo de atualização ou concepção de um novo produto, algumas ferramentas são aplicadas e testes são realizados para 
validar as modificações, inovações incorporadas no produto. Com isso, o teste final de campo será reduzido e poderá focar os aspectos não cobertos nos testes iniciais e/ou validar o sistema como um todo e não apenas o componente.

\subsection{Justificativa}

As informações a respeito do comportamento do produto no campo são fundamentais para que a Empresa:

- possa saber como está o desempenho de seu produto no campo;

- possa avaliar e, se necessário, propor ações corretivas em função de não-conformidades ocorridas no campo e que não foram detectadas durante as fases anteriores do desenvolvimento do produto (simulações, teste de bancadas, testes na linha de montagem, teste operacional dentro da fábrica, etc);

- possa evitar que as não-conformidades venham a ocorrer novamente, quando a máquina estiver em produção;

- possa estabelecer como base comparativa para evitar falhas no desenvolvimento de outras famílias de produto da própria Empresa ou na sua subseqüente nova fase de atualização;

- possa verificar e reduzir gastos com as garantias.

Porém, para que os dados de campo sejam considerados e iniciem ações, eles necessitam ser precisos, ricos em detalhes e comunicados imediatamente e eficazmente a Empresa, de forma a evitar interpretações 
equivocadas ou duvidosas, o que pode ocasionar desperdício de mão-de-obra qualificada na coleta, análise e solução das não-conformidades apontadas, podendo resultar em soluções temporárias e/ou inadequadas ao problema e, o mais grave, a insatisfação do Cliente final, com relação ao produto adquirido.

\subsection{Problema de Pesquisa em Forma de Perguntas}

As seguintes perguntas necessitam ser respondidas com o decorrer desta dissertação:

- Quais dados de Confiabilidade são coletados pela Revenda?

- De que forma os dados de Confiabilidade do produto são coletados?

- Qual a importância dos dados de Confiabilidade para a Empresa e por quê?

- Qual a dificuldade enfrentada pela Revenda na coleta de dados de Confiabilidade?

- De que forma os dados coletados são informados a Empresa ?

- Como a Empresa trabalha com os dados coletados pela Revenda?

- Como agilizar a solução das falhas / problemas enfrentados pelo Cliente? 


\section{$1.5 \quad$ Hipóteses}

Para a realização deste trabalho, algumas hipóteses foram consideradas, e dentre as mais importantes pode-se citar:

- o ciclo de vida do produto é em si uma descrição da vida do produto desde a identificação das necessidades até o descarte final. Em termos gerais as etapas do ciclo de vida do produto são: necessidades de mercado, planejamento do produto, processo de projeto, produção, uso/consumo e descarte (Dias, 2003);

- os produtos têm apresentado ciclo de desenvolvimento mais curto, com isso a concepção não tem recebido a devida ênfase, fazendo com que as fases: de conceito, validação e colocação do produto em produção não sejam seguidas adequadamente. Com isso, as não-conformidades acabam não sendo corrigidas, e o Cliente acaba sendo o grande prejudicado;

- as Revendas não coletam de forma completa os dados necessários a Empresa da Confiabilidade do produto no campo;

- muitos dados que chegam a Empresa são imprecisos, principalmente quando a fase de diagnóstico do problema não é feita adequadamente;

- a falta de registro dos problemas, principalmente dos esporádicos, prejudica bastante a velocidade de solução dos mesmos. 


\subsection{Relevância do Trabalho}

A busca incessante da melhoria contínua, principalmente da Confiabilidade dos produtos, faz com que novas metodologias e muitos trabalhos surjam a cada momento, propondo melhorarias durante as diversas fases de desenvolvimento do produto, desde o projeto, testes, fabricação, montagem e transporte.

Muitos trabalhos têm sido realizados propondo métodos para melhorar a Confiabilidade do produto durante a fase de projeto, teste, fabricação, montagem e transporte. Alguns trabalhos têm mostrado os fatores que levam a Empresa a não conseguir prever todas as falhas que ocorrem com o produto no campo e as causas desta dificuldade de previsão, assim como a importância dos dados de campo. Mas pouco tem sido feito quanto a propor métodos eficazes para coletar os dados de Confiabilidade com precisão (Vollert Jr, 1996).

Dentro destes poucos métodos, pode-se citar o CPI (Melhoria Constante do Produto), implementado em 2003 pela Empresa, utilizando a metodologia 6 Sigmas, que visa colher informações precisas, padronizadas e classificar, a fim de ordenar, priorizar e disciplinar a solução de problemas de campo.

\subsection{Limitação do tema de pesquisa}

A pesquisa se limita à análise do sistema atual de coleta, priorização e solução de problema de campo de uma das fábricas da Empresa, e de apenas uma de suas Revendas.

Apesar desta dissertação se restringir apenas a uma fábrica e uma Revenda, esta melhoria na metodologia poderá ser aplicada a todas as outras 
fábricas da Empresa e Revendas, visto que a estrutura organizacional e a estratégia mundial da Empresa que norteiam as diretrizes da área de Confiabilidade do produto são as mesmas, independentes de País ou região e, com a mesma prioridade.

A Empresa é uma Empresa global, líder absoluta de mercado em seus segmentos de atuação - construção, mineração, agricultura, florestal e industrial - vem investindo ao longo dos seus 50 anos de atividades industriais no Brasil em alta tecnologia e adota os mais modernos conceitos de excelência para flexibilizar suas operações e oferecer produtos e serviços da mais fina qualidade.

\subsection{Estrutura do Trabalho}

Este trabalho foi estruturado em 5 capítulos, em que o capitulo 1 é a introdução do trabalho e descreve a estrutura do mesmo.

O capítulo 2 traz a revisão bibliográfica com uma introdução sobre Confiabilidade, algumas normas de Confiabilidade, as tarefas da Confiabilidade durante as diversas fases do desenvolvimento de um produto, por que a Empresa não consegue predizer as falhas que ocorrem com o produto no campo, a importância dos dados de campo e suas limitações, e traz um levantamento sucinto dos principais dados de campo da Confiabilidade do produto, que são importantes para a Empresa.

O capítulo 3 traz uma descrição a respeito da Revenda escolhida para a realização deste trabalho, a sua estrutura organizacional, a importância da Revenda para a Empresa, os serviços que ela oferece ao Cliente, a dificuldade enfrentada pela Revenda, a forma de comunicação entre a Revenda e a Empresa. 
O capítulo 4 detalha a metodologia utilizada pela Empresa e apresenta uma proposta de melhoria na metodologia utilizada para coletar, classificar, priorizar e endereçar os dados de Confiabilidade do produto no campo, através de dados de reparo realizados pela Revenda e informados a Empresa.

O capítulo 5 apresenta recomendações e conclusões para trabalhos futuros. 


\section{CAPÍTULO II}

\subsection{Revisão da literatura}

A competição globalizada iniciada no final do século $X X$ tem estimulado a busca constante de alternativas para tornar a Empresa mais competitiva e, conseqüentemente, permitir sua entrada / aumento de sua participação no mercado. O trabalho constante para minimizar / eliminar as causas dos erros e desperdícios tem se tornado um dos fatores fundamentais para a conquista de Clientes e a sua lucratividade.

A satisfação do Cliente é um resultado alcançado, quando as características do produto correspondem às suas necessidades. Ela, geralmente é sinônimo da satisfação com o produto. A satisfação com o produto é um estímulo à sua facilidade de venda. O maior impacto é sobre a participação de mercado e, portanto, sobre a receita de Vendas (Juran, 2001).

O desperdício gerado por não-conformidade, seja durante o processo de manufatura, transporte, ou após a entrega do produto ao Cliente, tem sido alvo de constantes e incansáveis batalhas da Empresa. Essas batalhas têm 3 focos principais:

- atender a crescente expectativa do Cliente sobre qualidade, preços e prazo de entrega; 
- reduzir custo, principalmente o do re-trabalho, que podem ter graves conseqüências financeiras e de imagem causados pelas não-conformidades;

- suportar as pressões da concorrência, principalmente no preço.

\subsection{Definição de Confiabilidade}

A Confiabilidade é um dos mais importantes atributos do produto, visto que é uma das considerações primárias do Cliente, quando da aquisição de um novo produto, ou seja, a Confiabilidade no produto e/ou na companhia é um fator que direciona na hora da compra.

O consumidor adquire um produto porque já conhece a marca, porque confia na imagem da Empresa ou ainda porque desenvolveu uma relação de fidelidade com a Empresa por experiências anteriores. (Paladini, 2000).

Muitas são as definições de Confiabilidade. De uma forma geral, Confiabilidade pode ser definida como probabilidade de um item desempenhar uma determinada função, de forma adequada, durante um intervalo de tempo, sob condições especificadas (Revista brasileira de gestão e desenvolvimento de produto, março 2002).

Dentre as diversas definições da Confiabilidade a mais completa é: Confiabilidade é a probabilidade de que o produto desempenhará satisfatoriamente suas funções pretendidas, sem falhar, sob determinadas condições específicas e por um determinado período de tempo específico. (Vollert Jr, 1996). 
Define-se a Confiabilidade como um conceito global, que se decompõe em vários vetores quantificáveis (Ribeiro \& Guimarães, 1999):

- Confiabilidade (reliability):

- medida do tempo de funcionamento de um sistema até falhar, ou da probabilidade de não falhar durante o tempo de missão (ex.:MTTF, MTBF, 10-5 falhas/hora, 99.9\%).

- disponibilidade (availability):

- medida do tempo (ou \%) em que o sistema está operacional (ex.: MTBF/(MTBF+MTTR), 5000h/ano).

- reparabilidade (maintainability):

- medida do tempo de reposição em serviço do sistema (ex.: MTTR).

- segurança contra acidentes (safety):

- medida da Confiabilidade do sistema relativa a faltas que ocasionem efeitos catastróficos.

- segurança contra acesso não autorizado (security):

o idem, relativo a faltas contra integridade, confidencialidade e autenticidade. 
Oficialmente, a Confiabilidade é definida como a "probabilidade de um item realizar uma função requerida sob determinadas condições durante um período de tempo estabelecido" (ABNT - NBR ISO 8927, 2001).

Com base na definição acima, pode-se interpretar que a Confiabilidade de um produto, seja de um componente ou sistema, é a sua capacidade expressa por uma probabilidade:

- de funcionar corretamente conforme esperado;

- por um período de tempo pré-estabelecido;

- em condições operacionais e ambientais específicas.

A probabilidade está relacionada ao número de vezes que o sistema opera adequadamente. Sendo assim, uma Confiabilidade de $90 \%$ significa, em média, que o sistema desempenhou sua função adequadamente em 90 das 100 vezes que foi solicitado.

A Associação Brasileira de Normas Técnicas definiu a Confiabilidade da seguinte maneira:

- Confiabilidade inerente: Confiabilidade produzida de um item por si próprio nos estágios de ensaio do projeto, fabricação e Confiabilidade (ABNT NBR ISO 8927, 2001);

- Confiabilidade operacional: Confiabilidade afetada pelas condições de uso e serviço de uma máquina. A relação com a Confiabilidade inerente pode ser mostrada pela seguinte fórmula (ABNT NBR ISO 8927, 2001):

- $\mathrm{Co}=\mathrm{Ci} \times \mathrm{k}$ 
- Co = é a Confiabilidade operacional;

- $\mathrm{Ci}=$ é a Confiabilidade inerente;

- $K=$ é o fator de condição (normalmente $k<1$ ).

$\mathrm{Na}$ análise da Confiabilidade de uma grande gama de produtos, pode-se observar que existe uma variação muito grande no comportamento das falhas. Alguns apresentarão falhas no início de sua vida, outros no final; uns apresentarão falhas devido à alta, outros devido à baixa temperatura; uns apresentarão falhas durante, outros após o período de garantia. Com isso, uma das dificuldades da análise é saber qual é a melhor distribuição estatística que se adapta ao comportamento do produto em relação a suas falhas.

Os principais tipos de distribuições estatísticas utilizadas no estudo da Confiabilidade são:

- Weibull - é a mais geral, precisa e prática dentre todas as demais distribuições estatísticas utilizadas no estudo da Confiabilidade. Ela pode englobar, com suficiente precisão, a maioria dos casos práticos, isto é possível devido à influência do parâmetro de forma (B);

- Weibull Mista ou Multimodal - é aplicável para dois ou mais diferentes tipos e modos de falhas e na análise da vida total de um produto (falhas precoces, vida útil, após expectativa da vida útil);

- Exponencial - é um caso particular da distribuição de Weibull, com parâmetro de forma $b=1$. Sua grande aplicação prática ocorre nos sistemas com significativa quantidade de componentes 
em série (caso típico de equipamentos eletrônicos, em que a taxa de falha do sistema é constante);

- Lognormal - é aplicada, principalmente, quando ocorre uma significativa quantidade de falhas no início da vida do produto e poucas falhas no fim da vida, apresentando assimetria em relação ao valor médio;

- Normal - é aplicada, principalmente, quando não ocorrem falhas no início ou fim da vida do produto, concentrando-se em torno de um valor médio. Esta distribuição aproxima-se bastante da distribuição de Weibull para parâmetros de forma $B>>3.4$, sendo caracterizada por uma perfeita assimetria em relação ao valor médio.

A distribuição de Weibull (Falguera, 2002), é a expressão semi-empírica desenvolvida por Ernest Hjalmar Wallodi Weilbull, físico sueco, que em 1939 apresentou o modelo de planejamento estatístico sobre fadiga de material. Sua utilidade decorre do fato de permitir:

- representar falhas típicas de partida (mortalidade infantil), falhas aleatórias e falhas devido ao desgaste;

- obter parâmetros significativos da configuração de falhas;

- representação gráfica simples. 


\subsection{Classificação e definição de falha}

Especificar critérios de falha é muito difícil, visto que muitas delas são subjetivas. Sendo assim, entre os próprios Clientes existem diferentes percepções em relação ao visual ou mesmo ao próprio desempenho do produto. Além de que Cliente e Empresa podem divergir a respeito do que é exatamente uma falha ou um desempenho inadequado de um produto.

Além disso, um dos pontos mais difícil e importante para a Confiabilidade é a correta conceituação do que é falha, pane e defeito de um componente ou sistema, conforme descrito na norma ABNT - NBR - 5462 [N02] (Pallerosi, 2000):

- Falha - "o término da capacidade de um item de desempenhar a função requerida";

- Defeito - "qualquer desvio de uma característica de um item em relação a seus requisitos";

- Pane - "estado de um item, caracterizado pela incapacidade de desempenhar uma função requerida, excluindo a incapacidade durante a manutenção preventiva ou outras ações planejadas, ou pela falta de recursos externos".

Um modo de falha pode ser descrito como o efeito causador da falha em um item. Considerando que os itens são desenvolvidos para realizar uma ou mais funções, um modo de falha é, portanto, definido como a não realização de uma destas funções (Falcetta, 2000).

Não existe relacionamento entre os termos relativos à falha, porém, eles podem ser classificados como grupos de tempo, magnitude e causa, conforme mostrado na FIGURA 2.1 (ABNT NBR ISO 8927, 2001). 


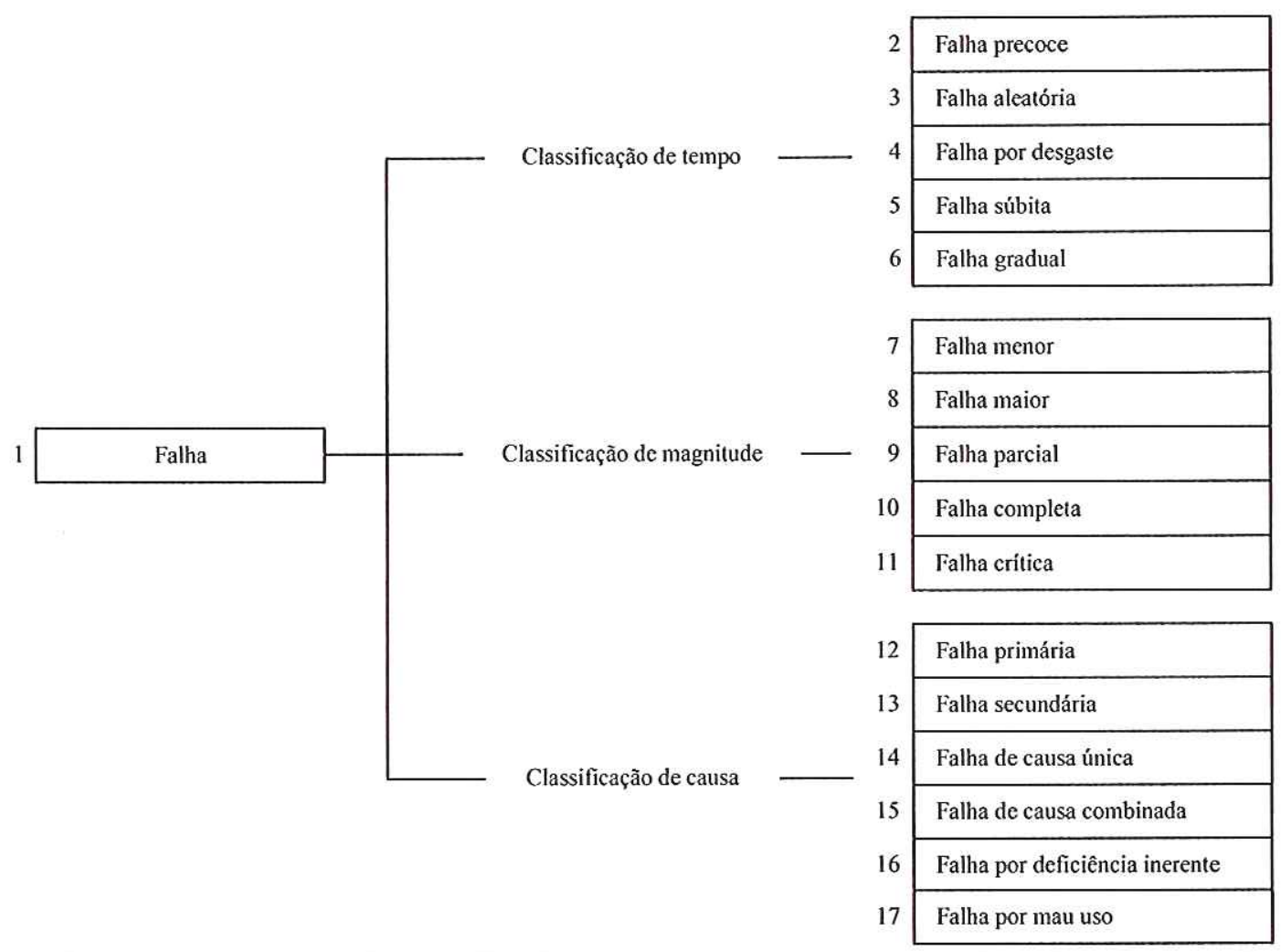

Legenda: $\square$ representa o campo abrangido nesta Norma.

Figura 2-1 - Classificação dos temas referentes a falha (ABNT NBR ISO 8927, 2001).

- Falha precoce: atribuível ao projeto, fabricação ou uso impróprio de um item que ocorre durante o período de garantia;

- Falha aleatória: ocorre ao acaso, entre o período de falha precoce e o período de falha por desgaste;

- Falha por desgaste: ocorre como um resultado de fadiga, desgaste, degradação e deterioração por envelhecimento; 
- Falha súbita: ocorre repentinamente e não pode ser prevista por exame ou monitoramento prévio;

- Falha gradual: é caracterizada pela deterioração gradual de um item e que pode ser prevista por exame ou monitoramento prévio;

- Falha menor: quando um item que não causa tempo inativo ou pode ser reparada dentro de $8 \mathrm{~h}$;

- Falha maior: quando ocorre possível redução ou interrupção da função de um sistema e/ou requer mais que $8 \mathrm{~h}$ para reparo;

- Falha parcial: não causa perda completa de função requerida;

- Falha completa: a função requerida de um item é completamente perdida;

- Falha crítica : pode provocar danos físicos às pessoas ou sérios danos ao produto;

- Falha primária: não causada direta ou indiretamente pela falha de outro item;

- Falha secundária: causada direta ou indiretamente por um outro item;

- Falha de causa única: ocasionada por uma causa única;

- Falha de causa combinada: ocasionada por uma combinação de duas ou mais causas; 
- Falha por deficiência inerente: atribuída à deficiência inerente de um item por si próprio, quando submetido a tensões dentro das capacidades determinadas do item, causada por erros no planejamento e execução do projeto, fabricação, etc;

- Falha por mau uso: atribuível à aplicação inadequada, causada pela operação, serviço, armazenamento, etc.

Deficiência do produto é uma falha do mesmo que resulta em insatisfação com o produto. As deficiências dos produtos assumem formas como interrupção no fornecimento de energia, entrega fora do prazo, bens inoperáveis, má aparência, ou desconformidade com as especificações (Juran, 2001).

\subsection{Confiabilidade e garantia}

Tradicionalmente, no processo de comercialização de bens e serviços, tem sido utilizada a instituição da garantia, durante um determinado período de tempo. Durante esse período o fornecedor (ou Empresa) compromete-se a consertar ou substituir, total ou parcialmente, o produto (ou componente dele) que apresentar defeitos operacionais ou construtivos sem ônus para o usuário (Helman \& Andery, 1995).

O período de garantia, na verdade, é um prazo pelo qual a Empresa garante, por escrito e sob as penas da lei, que seu produto, processo ou serviço está de acordo com os requisitos especificados em normas e regulamentos. Em outras palavras, durante um determinado período a Empresa compromete-se a consertar, substituir parcialmente ou na íntegra o produto defeituoso (material ou operacional), desde de que o mesmo não tenha sido causado intencionalmente ou acidentalmente pelo Cliente. A garantia mais 
comum praticada no mercado, em geral, é de 12 meses, em alguns casos limitados a um certo número de horas. Nesse caso, a garantia encerra-se a partir do momento em que uma das duas condições acontecer.

A legislação brasileira prevê dois tipos de garantia, porém não é específica no que diz respeito a prazo:

- garantia legal de adequação do produto ou serviço independente de termo expresso, vedada a exoneração contratual do fornecedor artigo 24 do Código de Defesa do Consumidor - Lei 8078/90, (Grinover et al., 1999) :

- esta garantia, que independe de documento escrito, significa que o fornecedor deve colocar no mercado de consumo produtos ou serviços de boa qualidade, vale dizer, sem vícios ou defeitos que os tornem impróprios ao uso e consumo ou Ihes diminuam o valor.

- garantia contratual é complementar à legal e será conferida mediante termo escrito - artigo 50 do Código de Defesa do Consumidor - Lei 8078/90, (Grinover et al., 1999) :

- ao contrário da garantia legal, que é sempre obrigatória, a garantia contratual é mera faculdade, que pode ser concedida por liberalidade do fornecedor. Portanto, os termos e o prazo dessa garantia contratual ficam ao alvedrio exclusivo do fornecedor, que os estipulará de acordo com sua conveniência, a fim de que seus produtos ou serviços possam ter competitividade no mercado, atendendo, portanto, ao principio da livre iniciativa;

- o termo de garantia ou equivalente deve ser padronizado e esclarecer, de maneira adequada, em que consiste a mesma 
garantia, bem como a forma, o prazo e o lugar em que pode ser exercitada e os ônus a cargo do consumidor, devendo ser-lhe entregue, devidamente preenchido pelo fornecedor, no ato do fornecimento, acompanhado de manual de instrução, de instalação e uso de produto em linguagem didática, com ilustrações.

Embora a garantia represente uma segurança ou tranqüilidade para o Cliente, o fato do Cliente não dispor do produto durante o período de conserto do mesmo ou de ficar sem ele com demasia freqüência, representa, no mínimo, um motivo de insatisfação (quando não de prejuízos econômicos) e uma perda de prestigio para o fornecedor e sua Empresa (Helman \& Andery, 1995).

Especificamente, em relação à Empresa onde serão realizados os casos de testes, ela possui no seu termo de garantia, (Caterpillar, 2003):

- Responsabilidade da Empresa - No caso de um defeito de material ou de fabricação, a Empresa, durante o expediente normal de trabalho e numa dependência comercial de uma de suas Revendas ou de outra fonte, por ele aprovada, tomará as seguintes providências:

- fornecerá (a critério da Empresa) peças ou componentes montados novos, re-manufaturados ou reparados aprovados pela Empresa, necessários para corrigir o problema;

- substituirá óleo lubrificante, filtros e outros itens de serviço inutilizados pelo defeito;

- fornecerá a mão-de-obra módica e costumeira necessária para corrigir o defeito, exceto no caso de componentes instalados por outra Revenda, não aquela da rede da Empresa; 
- Responsabilidade do Usuário:

o fornecer comprovante da data de entrega ao primeiro usuário;

- custos associados ao transporte do produto;

- custo de mão-de-obra, exceto aqueles relacionados sob o título "Responsabilidade da Empresa";

- impostos locais, se aplicáveis;

- despesas referentes ao envio de peças, além das despesas consideradas usuais e costumeiras;

- custos associados à investigação de reclamações, a menos que o problema tenha sido causado por um defeito de material ou de fabricação da Empresa;

- fornecer notificação prévia da falha a ser coberta por garantia e colocar o produto à pronta disposição para reparo;

- executar a manutenção requerida e a reposição de itens devido ao desgaste normal;

- permitir o acesso da Empresa a todos os dados armazenados eletronicamente.

- Limitações:

- o fornecedor não é responsável por falhas resultantes de: 
- qualquer uso ou instalação considerados inadequados pela Empresa;

- componentes suplementares, itens acessórios e peças não vendidas ou aprovadas pela Empresa;

- abuso, negligência e/ou reparo inadequado;

- reparos ou ajustes não autorizados ou mudanças não autorizadas no ajuste de combustível;

- atraso por parte do usuário em colocar o produto à disposição após ter sido notificado a respeito de um possível problema do produto.

Empresas e revendedores compartilham os custos de garantia, participando a Empresa com os custos de material, peças, taxa de serviço de peças, mão-de-obra para recuperação de peças; enquanto a Revenda entra com o custo de mão-de-obra, máquina e ferramentas para o reparo, viagem, refeição, estadia em hotel.

\subsection{Engenharia de Confiabilidade}

A Engenharia de Confiabilidade tem sido desenvolvida em resposta à necessidade de controlar os riscos de desenvolvimento do produto, o qual tem aumentado nos últimos anos, principalmente devido à competição acirrada, seja devido à pressão de datas (prazos), custo da não-conformidade, da rápida evolução de novos materiais, de métodos e complexos sistemas, da necessidade de reduzir o custo do produto e de considerações de segurança, FIGURA 2.2 (O' Connor, 1991). 


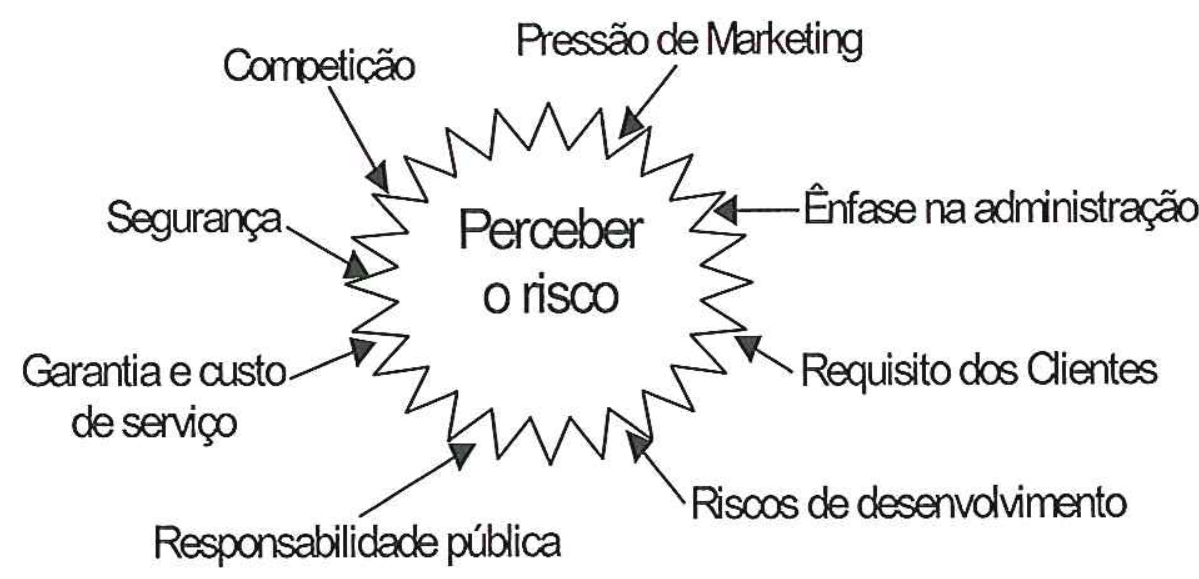

Figura 2-2 - Percepção do Risco (O'Connor, 1991)

A Confiabilidade e a disponibilidade compreendem a base da engenharia de Confiabilidade de software (ECS) que é definida como o estudo quantitativo do comportamento operacional de sistemas de software com base nos requisitos de usuário relativo à Confiabilidade (Silva Filho, 2003).

Por meio desta metodologia é possível analisar o tempo de falha de produtos em campo, planejar testes de vida acelerados e avaliar a Confiabilidade do produto (Falguera, 2002). A engenharia de Confiabilidade envolve estatística aplicada na manutenção corretiva, preventiva, preditiva, disponibilidade, árvore de falhas, análise de custo de ciclo de vida, etc.

\subsection{Normas de Confiabilidade e manutenibilidade}

A facilidade com que o reparo e outro trabalho de manutenção possa ser executado determina um sistema de manutenibilidade (O' Connor, 1991). 
A manutenibilidade é a medida relativa à facilidade de realizar as ações para prevenir falha (ABNT NBR ISO 8927, 2001). Em outras palavras, a propriedade ou probabilidade das ações que previnem falhas, as quais podem ser realizadas sob as condições dadas dentro de um período determinado.

Diversas são as normas que abrangem a Confiabilidade e manutenabilidade, dentre as quais tem-se:

- US MIL-HBK-217 - Reliability Prediction of Electronic Equipment (Reliability Standards \& Handbooks):

- utilizada para estabelecer e manter métodos consistentes e uniformes para estimar Confiabilidade inerente a equipamento e sistema eletrônico:

- técnica de predição de análise de stress em componente;

- técnica de predição de Confiabilidade por quantidade de peça, usando inicialmente a quantidade de peças por categoria, considerando a qualidade da peça, o meio ambiente, a maturidade do processo de produção.

- MIL-STD-470 - Maintainability Program Requirements for Systems and Equipment (Maintainability Standard \& Handbooks):

o inclui requisitos de aplicação, tarefas de programa de manutenabilidade "especifico e único para cada caso", e um apêndice com uma matriz de aplicação, orientação e análise racional para tarefas selecionadas. 
- MIL-STD-471A - Maintainability Verification, Demonstration, Evaluation (Maintainability Standard \& Handbooks):

o provê procedimentos e métodos de teste para verificação, demonstração e avaliação dos requisitos qualitativo e quantitativo de manutenabilidade.

- MIL-HDBK-472 Maintainability Prediction (Maintainability Standard \& Handbooks):

- esta norma tem como intuito familiarizar gerentes e engenheiros de projetos com os procedimentos de predição da manutenabilidade.

- MIL-STD-756 - Reliability Modeling and Prediction (Reliability Standards \& Handbooks):

- estabelece procedimentos uniformes e regulamento básico para a geração da missão da Confiabilidade e predição e modelo de Confiabilidade básico para sistemas e componentes elétrico, eletrônico, eletromecânico, mecânico e peca de artilharia.

- MIL-STD-781 Reliability Testing for Engineering Development, Qualification and Production (O'Connor, 1991):

- provê detalhes dos métodos e ambientes de testes, bem como métodos de monitoramento do crescimento da Confiabilidade.

- MIL-STD-785 - Reliability Program for Systems and Equipment, Development and Production (Reliability Standards \& Handbooks): 
- provê requisitos gerais e tarefas específicas para o programa de Confiabilidade. É utilizado para o planejamento do programa de Confiabilidade e inclui descrições de tarefas para requisito de aplicação básica, incluindo, no programa, seções de fiscalização e controle, desenho e avaliação e teste de desenvolvimento e produção.

- MIL-STD-810 (Vollert Jr, 1996):

- utilizada para os testes de stress ambiental.

- MIL-STD-1629A - Procedures for Performing a Failure Mode, Effects, and Criticality Analysis (USA Military Standard, 1980):

- estabelece os requisitos e procedimento para desenvolver uma análise crítica de do modo e efeito da falha.

- MIL-STD-1635 (Vollert Jr, 1996):

- utilizada para programas de teste de crescimento da Confiabilidade.

- MIL-STD-2068 (Vollert Jr, 1996):

- utilizada para avaliar a Confiabilidade durante a fase de desenvolvimento do produto.

- MIL-STD-2074 - Failure Classification for Reliability Testing (Reliability Standards \& Handbooks):

- estabelece critérios para a classificação de falhas ocorridas. 
- MIL-STD-2164 Environment Stress Screening Process for Electronic Equipment (Reliability Standards \& Handbooks):

- define requisitos para ESS de equipamento eletrônico, incluindo condições de teste de ambientes, duração da exposição, procedimento, operação do equipamento, ação tomada para detecção de defeito e documentação do teste.

- BS EN 61014:2003 (British Standard, 2003):

- especifica requisitos e provê diretrizes para demonstrar e remover pontos fracos em hardwear e software para o crescimento da Confiabilidade.

\subsection{Tarefas da Confiabilidade}

Os conceitos básicos para o crescimento da Confiabilidade de um produto são similares, quer os pontos fracos do produto sejam descobertos durante a fase de desenho, análise ou teste.

O crescimento da confiabilidade é uma melhoria dos parâmetros de confiabilidade em relação às mudanças do projeto de um produto ou de um processo industrial (Schaedler, 2003).

No programa de análise de desenho do crescimento da Confiabilidade, 0 desenho do produto é analisado a fim de determinar se qualquer um de seus componentes e/ou suas interações constitui ponto fraco em potencial, quando submetido à operação normal (esperada), stress ambiental e seus potenciais stress. Os resultados das análises de desenhos devem ser comparados com o 
objetivo de Confiabilidade ou requisitos pré-estabelecidos, e recomendações são feitas para melhorias necessárias.

No programa de teste do crescimento da Confiabilidade, laboratório ou teste de campo, é usado para simular a exposição dos pontos fracos e para melhorar a Confiabilidade do sistema, módulo, submontagem ou componente. Quando uma falha ocorre, deve ser diagnosticada, reparada e/ou substituída, ou seja, ela deve ser sanada; e o teste deve continuar. Paralelamente com o teste, falhas antigas devem ser analisadas para que as causas raízes sejam encontradas e, se necessário, sejam melhorados o desenho ou outro procedimento, resultando em progressivo crescimento da Confiabilidade.

\subsubsection{Tarefas da Confiabilidade durante a fase de projeto}

Durante esta fase, todo método analítico de Confiabilidade pode ser aplicado para o crescimento da Confiabilidade, incluindo específicos designados para detectar potenciais modos de falha, especialmente aqueles em que as análises deveriam ser muito complexas, ou devem produzir resultados incertos.

Os seguintes passos são necessários para projetar para a Confiabilidade:

- definir requisitos realísticos do sistema: todo produto é requerido a operar através de uma variedade de condições ambientais por um período específico de tempo. A Empresa e o Cliente devem em conjunto definir os requisitos do sistema;

- definir o ambiente de uso do sistema: a Empresa e o Cliente devem especificar conjuntamente todas condições operacionais, tais como: 
de transporte, de armazenamento, etc, relevantes, incluindo cargas mecânicas, elétricas, e térmicas, e devem juntamente avaliar os prós e os contras;

- identificar os locais potenciais das falhas e os mecanismos de falha: toda informação possível sobre os modos de falha potenciais, os locais, e os mecanismos causadores das falhas devem ser identificados precocemente na fase de projeto. O diagrama de Ishikawa (Diagrama de causa e efeito) e análise de criticidade do modo e efeito da falha (FMECA - Failure Mode and Effects Criticality Analysis), podem ser usados para esta análise. O diagrama de Pareto pode ser utilizado para avaliar a importância de cada tipo de falha e determinar, por hierarquia, quais destas são mais importantes;

- categorizar os materiais e os processos de manufatura e montagem: todos os materiais devem ser categorizados e suas características principais, controladas. Características principais incluem tipos e níveis de defeitos, tanto como variações esperadas nas propriedades e dimensões dos materiais, como em processo de manufatura e montagem. Estas variações podem afetar significativamente 0 desempenho do produto ao longo do tempo;

- qualificar o processo de manufatura e montagem: todos os processos de manufatura e montagem devem ser capazes de produzir o produto. As características principais do processo devem ser identificadas, medidas e otimizadas utilizando projeto de experimentos;

- controlar os processos de fabricação e montagem: testes específicos de screening ambiental, baseados nos resultados dos itens anteriores devem ser usados para detectar e fazer triagem de defeitos; 
- gerenciar o ciclo de vida do produto: avaliações contínuas através de feedbacks de dados de testes de vida, screening, projeto, manufatura, do campo, etc, devem ser utilizadas para melhorar a qualidade, Confiabilidade e custos;

- sempre que possível o projeto deve ser simplificado: um menor número de componentes sempre é desejável para melhorar a Confiabilidade do sistema.

Estes passos acima citados foram desenvolvidos por Pecht (1993), mas os que normalmente são abordados em quase todas as literaturas sobre Confiabilidade serão descritos a seguir (Vollert Jr, 1996):

- análise e verificação de projeto: é o uso de métodos científicos, normalmente matemáticos para examinar os parâmetros de projeto e suas interações com o ambiente. Visto que engenheiros utilizam muitas hipóteses, o projeto é freqüentemente realizado através de um processo interativo ou contínuo de análises e testes que utilizam o conhecimento da engenharia como normas, procedimentos, resultado das análises, modelagem, simulação e testes. Uma lista de itens a serem verificados e considerados na revisão do projeto do produto e do processo é fornecida abaixo (Hellman \& Andery, 1995);

- estudos de pros e contras de projeto: o objetivo principal é que, através das várias alternativas e critérios envolvidos em um projeto como: custo, desempenho, Confiabilidade, tempo, produtividade, qualidade e outras características, encontrar o ótimo balanço entre estas alternativas, com o propósito de otimizar o desempenho total do sistema e reduzir o risco técnico;

- análise dos stress ambientais: para um projeto bem sucedido, é muito importante que todos os fatores ambientais que interagem com 
o produto, em seu uso real, sejam consideradas. A análise de stress ambiental é o estudo destes fatores, que afetam a Confiabilidade do produto no campo;

- análise do pior caso: é um método utilizado para avaliar a habilidade de um projeto reunir os requisitos operacionais e ambientais, sobre a pior combinação possível de circunstâncias. Se o desempenho global do produto ou sistema, permanecer dentro dos limites especificados, então o projeto mostrou ser confiável sob a pior condição possível. 0 problema deste enfoque é que, por ser rigoroso, normalmente acaba superdimensionando os componentes do produto. Portanto, ele deve ser utilizado só em componentes ou subsistemas que não podem falhar ou não se espera falhar;

- método da variação dos parâmetros: este método é um pouco menos rigoroso, variando de um a dois parâmetros de projeto por vez aos seus máximos e mínimos, enquanto os outros são mantidos constantes. Se cada parâmetro permanecer dentro dos limites seguros de especificação, o produto poderá desempenhar satisfatoriamente sua função. Também é conhecido como análise de sensibilidade.

Uma vez descrito os itens que norteiam o projeto rumo à Confiabilidade. As tarefas mais utilizadas da Confiabilidade são:

\subsubsection{Previsão da Confiabilidade}

Identificada a limitação fundamental dos dados e modelos da previsão da Confiabilidade, é possível fazer razoáveis previsões confiáveis para sistemas sob certas circunstâncias (O'Connor, 1991): 
- o sistema a ser projetado é similar ao sistema desenvolvido, fabricado e usado anteriormente, então pode-se aplicar as experiência sobre o que foi vivenciado;

- o novo sistema não envolve significante risco tecnológico (aplica-se o item anterior);

- o sistema será fabricado em larga escala ou é muito complexo (ex: contém muitas peças, ou as peças são complexas) ou será usado por longo tempo, ou uma combinação dessas condições aplicadas (ex: existe uma propriedade não determinada);

- Existe um forte comprometimento para o atingimento da previsão da Confiabilidade, como um desvio de prioridade.

A Previsão da confiabilidade é o processo quantitativo de estimar a confiabilidade inerente de um sistema, isto é, a confiabilidade que é determinada por ser tecnicamente atingível em um projeto dentro de suas metas de custo e tempo. A confiabilidade inerente é um valor razoável que se espera alcançar em um sistema quando este estiver maduro. O processo da Previsão da Confiabilidade deve ser usado no início da fase de avaliação do conceito. A previsão de Confiabilidade da John Deere envolve os seguintes aspectos: detecção de problemas potenciais da confiabilidade, feedback referente aos problemas potenciais e reprojeto baseado nos problemas identificados. A FIGURA 2.3 mostra a metodologia utilizada pela John Deere para determinar a Previsão da Confiabilidade (Schaedler, 2003). 


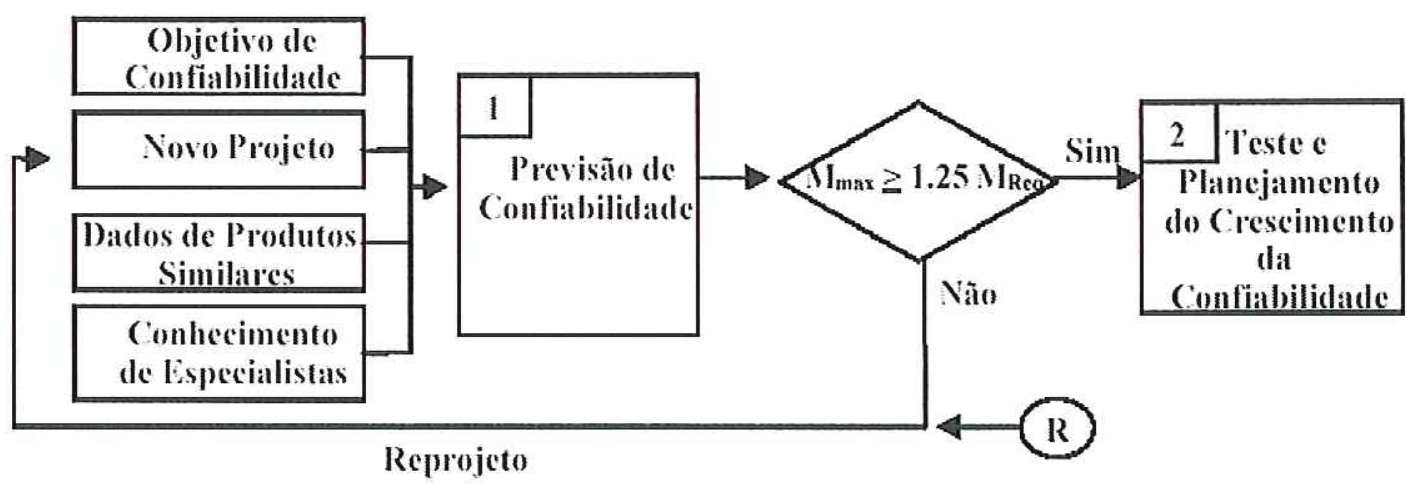

Figura 2-3 - Fluxograma da Previsão de Confiabilidade (Schaedler, 2003)

\subsubsection{Análise do Modo e Efeito da Falha}

A FTA e FMEA são métodos de análise de produtos e processos que permitem uma avaliação sistemática e padronizada de possíveis falhas, estabelecendo suas conseqüências e orientando a adoção de medidas corretivas. Esses métodos podem auxiliar eficientemente na etapa de buscas das causas fundamentais dos problemas bem como na etapa de elaboração do correspondente Plano de Ação para seu bloqueio (Helman \& Andery, 1995).

No método FTA (Fault Tree Analysis - Análise da Árvore de Falhas), a lógica é de cima para baixo, ou seja, a falha do sistema é denominada de evento de topo e é feito um desdobramento do nível superior para os inferiores, como galho de árvores.

No método FMEA (Failure Mode and Effects Analysis - Análise do Modo e Efeitos das Falhas) é examinada a falha nas peças e componentes e suas conseqüências para os níveis superiores correspondentes.

Os dois métodos que têm como objetivo medidas corretivas, apresentam as seguintes diferenças entre si (Helman \& Andery, 1995). (FIGURA 2.4) (TABELA 2-1). 


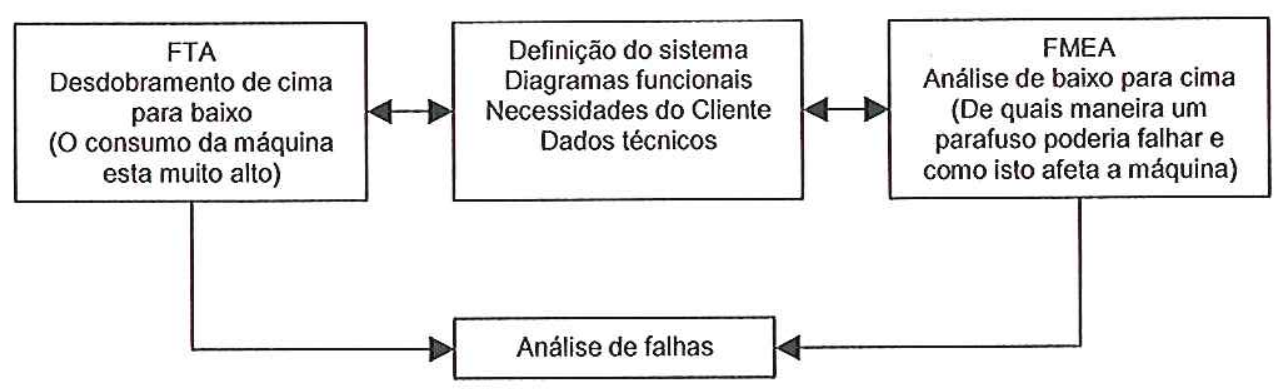

Figura 2.4 - Compara FTA e FMEA (Helman \& Andery, 1995)

Tabela 2-1 - Comparação entre os métodos (Helman \& Andery, 1995)

\begin{tabular}{|c|c|c|}
\hline & FTA & FMEA \\
\hline Objetivo & $\begin{array}{l}\text { Identificação das causas } \\
\text { primárias das falhas. } \\
\text { Elaboração de uma relação } \\
\text { lógica entre falhas primárias e } \\
\text { falha final do produto. } \\
\text { Análise da Confiabilidade do } \\
\text { sistema }\end{array}$ & $\begin{array}{l}\text { Identificação das falhas críticas } \\
\text { em cada componente, suas } \\
\text { causas e conseqüências. } \\
\text { Hierarquizar as falhas. } \\
\text { Análise da Confiabilidade do } \\
\text { sistema }\end{array}$ \\
\hline Procedimento & $\begin{array}{l}\text { Identificação da falha (evento) } \\
\text { que é detectada pelo usuário do } \\
\text { produto. } \\
\text { Relacionar essa falha com } \\
\text { falhas intermediárias e eventos } \\
\text { mais básicos por meio de } \\
\text { símbolos lógicos. }\end{array}$ & $\begin{array}{l}\text { Análise das falhas em potencial } \\
\text { de todos os elementos do } \\
\text { sistema, e previsão das } \\
\text { conseqüências. } \\
\text { Relação de ações corretivas } \\
\text { (ou preventivas) a serem } \\
\text { tomadas }\end{array}$ \\
\hline Característica básica & $\begin{array}{l}\text { Melhorar método para análise } \\
\text { individual de uma falha } \\
\text { específica. } \\
\text { O enfoque é dado à falha final } \\
\text { do sistema. }\end{array}$ & $\begin{array}{l}\text { Pode ser utilizado na análise de } \\
\text { falhas simultâneas ou co- } \\
\text { relacionadas. } \\
\text { Todos os componentes do } \\
\text { sistema são passiveis de } \\
\text { análise. }\end{array}$ \\
\hline
\end{tabular}

FMEA é uma técnica que oferece 3 funções distintas (Palady, 1997):

- ferramenta para prognóstico de problemas: 
- é uma das técnicas de baixo risco mais eficiente para prevenção de problemas e identificação das soluções mais eficazes em termos de custos, a fim de prevenir esses problemas.

- procedimento para desenvolvimento e execução de projetos, processos ou serviços, novos ou revisados:

- oferece uma abordagem estruturada para avaliação, condução e atualização do desenvolvimento de projetos e processo ou serviço, e se mantém através da vida de mercado do produto.

- é o diário do projeto, processo ou serviço:

o inicia-se na concepção do projeto, processo ou serviço, e se mantém através do ciclo de vida do produto.

Qualquer modificação durante esse período, que afete a qualidade ou a Confiabilidade do produto, deve ser avaliada e documentada no FMEA.

Essa ferramenta é mais eficaz quando aplicada em equipe, porém pode ser executada individualmente. Obviamente que o FMEA feito em equipe apresenta maiores chances na identificação e prevenção dos modos de falha potenciais, porém também apresenta maior custo. Sendo assim, as vantagens e desvantagens de cada possibilidade (individual ou em equipe), deve ser avaliado na relação custo $\mathrm{x}$ benefício.

O desenvolvimento e a execução do FMEA geram custos, porém aplicados de forma eficaz, podem resultar em significativo retorno de qualidade e Confiabilidade. Esse retorno é obtido através da redução do custo de falha no projeto, processo e serviço. 
Dois tipos de FMEA são mais comumente conhecidos, desde o seu desenvolvimento em meados da década de 60:

- FMEA de projeto - DFMEA - Design Failure Modes and Effects Analysis é uma técnica analítica utilizada primeiramente pela equipe responsável pelo projeto para garantir que, em toda sua extensão, os modos de falhas potenciais e suas causas associadas tenham sido consideradas e endereçadas. O risco de falha é reduzido (AGCO, 2003):

- auxiliando a avaliação objetiva de alternativas durante o projeto;

- auxiliando o projeto inicial nos requisitos de manufatura e montagem;

- aumentando a probabilidade de que os modos de falha potencial e seus efeitos no sistema tenham sido considerados no projeto de desenvolvimento do processo;

o provendo informações adicionais para auxiliar no completo planejamento e eficiência dos programas de teste;

- desenvolvendo uma lista de modos de falha potenciais, ordenando de acordo com o seu provável efeito sobre o Cliente. Desta forma, estabelece um sistema de prioridades para melhorias de projeto e desenvolvimento de testes;

o fornecendo, de forma aberta, formato documentado para recomendações e rastreabilidade de ações para reduzir os riscos; 
- provendo uma referência futura para auxiliar na análise de reclamações de campo, avaliação de alterações de projeto e desenvolvimento de projetos avançados.

- FMEA de processo - PFMEA (Process Failure Modes and Effects Analysis). Usado para minimizar o risco de falhas no projeto de produto, como por exemplo:

- identificando produtos potencialmente relacionados com modos de falha de processo;

- avaliando os efeitos das falhas no Cliente;

- Identificando potenciais falhas nos processos: de manufatura e montagem, localizando variáveis de processos com o objetivo de focar controles para redução de ocorrência ou auxiliar na detecção. Definindo áreas, em que dispositivos "à prova de erros" são necessários;

o desenvolvendo uma lista ordenada de modo de falhas potenciais, com o objetivo de estabelecer um sistema de prioridades na análise de ações corretivas;

- documentando / registrando os resultados dos processos de manufatura e montagem, servindo como futura referência para auxílio na análise das falhas de campo.

Além destes, existem outros dois tipos de FMEA (Schneider, 2001):

- FMEA de sistema: 
- usado para analisar sistemas e subsistemas no estágio de concepção do produto.

- FMEA de serviço:

- Utilizado para analisar os modos de falhas em prestação de serviço.

Os elementos básicos do FMEA, a fim de garantir seu sucesso, são os seguintes:

- selecionar o projeto de FMEA com maior potencial de retorno de qualidade e Confiabilidade;

- perguntar e responder às três perguntas:

- Como pode falhar?

- Por que falha?

- O que acontece, quando falha?

- implementar um esquema para identificar os modos de falha mais importantes, a fim de trabalhar neles ou melhorá-los:

○ ocorrência;

o severidade;

○ detecção. 
- priorizar ou selecionar os modos de falha potenciais que serão tratados em primeiro lugar:

○ interpretação.

- Acompanhamento:

- a construção e a análise da FMEA exigem a utilização de outras ferramentas de suporte à qualidade e Confiabilidade. Normalmente são utilizados métodos estatísticos, antes de preencher cada coluna do FMEA.

\subsubsection{3 Árvore de falha}

A FTA é um método sistemático e padronizado (Helman \& Andery, 1995), capaz de fornecer bases objetivas para funções diversas tais como a análise de modos comuns de falhas em sistemas, justificação de alterações em sistemas e demonstração de atendimento a requisitos regulamentares e/ou contratuais, dentre outras.

Esse método (desenvolvido em 1961 por H.A. Watson, do Bell Telephone Laboratories) foi desenvolvido para avaliar o grau de segurança do sistema de controle de lançamentos dos mísseis Minuteman. Posteriormente foi adaptado a outras funções, abrangendo desde projetos de máquinas e equipamentos até à análise de processos industriais ou administrativos (Helman \& Andery, 1995).

O FTA é útil para:

- auxiliar o analista a identificar dedutivamente as falhas do sistema; 
- assinalar os aspectos do sistema mais relevantes em relação a uma falha em particular;

- fornecer ao analista uma maior compreensão do comportamento do sistema.

A análise do FTA se inicia a partir de uma falha ou de um problema, em específico do sistema, a qual é denominada de "evento de topo", a seguir é feito o seqüenciamento ou a combinação de fatos, capazes de conduzir ao tal evento.

A FTA é um modelo gráfico que permite mostrar, de uma maneira simples, o encadeamento dos diferentes eventos que podem dar por resultado o evento do topo. A análise parte de uma situação anormal do sistema e desce até as causas mais básicas, cuja análise não necessita ser aprofundada. Estes eventos constituem o denominado limite de resolução da árvore. Depois de definido o conjunto de eventos que constituem o limite da árvore e identificadas as denominadas causas básicas, deverá ser elaborado um plano de ação visando ao bloqueio das mesmas.

As finalidades do FTA são:

- estabelecer um método padronizado de análise de falhas ou problemas, verificando como ocorrem em um equipamento ou processo;

- análise da Confiabilidade de um produto ou processo;

- compreensão dos modos de falha de um sistema, de maneira dedutiva;

- priorização das ações corretivas que serão tomadas; 
- análise e projeto de sistemas de segurança ou sistemas alternativos em equipamentos;

- compilação de informações para manutenção de sistemas e elaboração de procedimentos de manutenção;

- indicação clara e precisa de componentes mais críticos ou condições críticas de operação;

- compilação de informações para treinamento na operação de equipamentos;

- compilação de informações para planejamento de testes e inspeção;

- simplificação e otimização de equipamentos.

A estrutura da árvore de falha pode ser definida conforme a FIGURA 2.5.

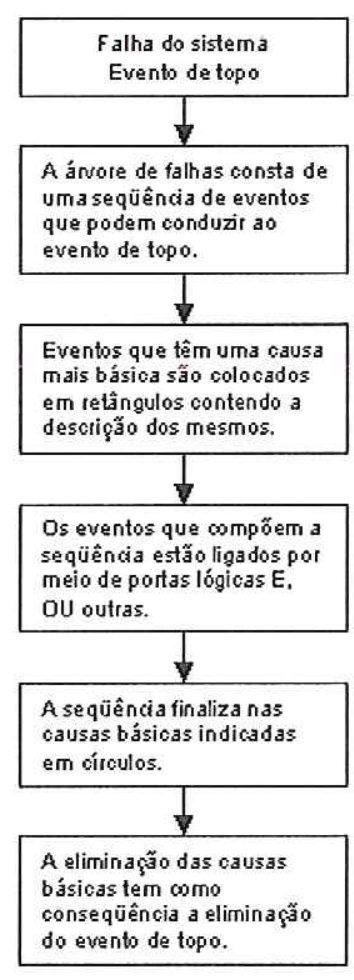

Figura 2-5 - Estrutura FTA (Helman \& Andery, 1995) 
Uma análise na FTA permite avaliar qual é o real conhecimento que a Empresa tem sobre o produto ou processo. Árvores de falha que abordam um mesmo evento de topo podem ser diferentes entre si, visto que diferentes pessoas podem ter uma compreensão distinta do sistema.

\subsubsection{Tarefa da Confiabilidade durante a fase de teste}

Teste é uma parte essencial no programa de desenvolvimento de um produto, se os riscos de desenvolvimento são altos, o programa de teste passa a ser um dos maiores componentes do esforço geral do programa em desenvolvimento, em termo de tempo e recurso alocado (O' Connor, 1991). Sendo assim, o teste de Confiabilidade deve ser considerado como parte de um programa de teste integrado, o qual deverá incluir:

- teste estatístico, para otimizar o desenho do produto e os processos de produção;

- teste funcional, para confirmar que o desenho atende os requisitos de desempenho básico;

- teste no ambiente de trabalho do Cliente, para assegurar que o desenho é capaz de operar sobre as expectativas de variações das condições de trabalho;

- teste de Confiabilidade,para assegurar que o produto operará sem falhas durante sua vida útil esperada;

- teste de segurança, quando apropriado. 
Em programa de aumento da Confiabilidade durante a fase de projeto do produto, o desenho é analisado para determinar se alguma de suas interações constituirá ponto fraco potencial, quando for submetido às operações e stress ambiental, para os quais foi planejado. O resultado da análise do projeto deve ser comparada com o objetivo de Confiabilidade do produto ou requisitos, e recomendações necessárias feitas para a melhoria requerida. É nessa fase que os pontos fracos e seus respectivos modos de falhas tornam-se instrumentos para determinar falhas em potenciais, melhorias e permitir o crescimento da Confiabilidade.

O programa de crescimento da Confiabilidade, seja realizado por testes laboratoriais ou em teste de campo, é usado para simular o produto à exposição de seus pontos fracos e melhorar a Confiabilidade do sistema, equipamento, componente ou item similar. Quando uma falha ocorrer, ela deverá ser diagnosticada, reparada e/ou a peça deverá ser substituída, e o teste deverá continuar. Paralelamente ao teste, as peças falhadas devem ser analisadas para que as respectivas causas raízes sejam encontradas e, quando apropriadas, melhorias corretivas devem ser introduzidas no projeto e seus procedimentos, resultando no crescimento da Confiabilidade.

\subsubsection{Teste de Crescimento da Confiabilidade}

Atualmente os objetivos de Confiabilidade são cada vez mais agressivos e o tempo programado para o seu desenvolvimento é cada vez menor. Com isso não mais é possível desenvolver o produto, depois testar, depois produzir e finalmente vender. No método de desenvolvimento atual do produto, 0 trabalho da Confiabilidade deve ser integrada na atividade do projeto, fazendo com que a confiança no projeto seja gradualmente incorporada na fabricação do produto, até ele ser produzido e liberado para o mercado. 
Segundo Deppe, 1994, da Boeing Corporation, o objetivo destes testes é melhorar a qualidade e a maturidade do produto, antes de sua introdução no campo, através de detecção das suas deficiências, determinar as causas fundamentais das falhas e implementar ações corretivas apropriadas para cada deficiência, antes de liberar o produto para o uso. Ele é essencial para a eliminação de deficiências de projeto e manufatura de novos produtos (Vollert Jr, 1996).

Segundo Bentz, 1984, o objetivo é aplicar o método de crescimento da Confiabilidade dentro da fase de desenvolvimento do produto, de forma que o programa de testes e desenvolvimento seja realizado simultaneamente com o de crescimento da Confiabilidade (Vollert Jr, 1996).

Segundo Crow, 1994, o crescimento da Confiabilidade é alcançado através de mudanças no projeto, que ocorrem durante os testes de desenvolvimento. Este programa, aplicado à fase de desenvolvimento do produto, tem a vantagem em relação ao programa convencional de crescimento da Confiabilidade, visto que no programa convencional testes de crescimento da Confiabilidade e implementações de mudanças de projeto só ocorrem após um produto ser interceptado no campo devido a uma falha indesejável, enquanto na fase de desenvolvimento melhorias são feitas antes do produto ser liberado ao Cliente (Vollert Jr, 1996).

Segundo Bieda, 1991, o teste de crescimento da Confiabilidade é um método viável para identificar modos de falhas, incorporar mudanças de projeto e monitorar o progresso da Confiabilidade durante as fases preliminares de desenvolvimento de um produto. Teste de crescimento da Confiabilidade é uma ferramenta bem influente e necessária para facilitar a detecção e eliminação preliminar de problemas (Vollert Jr, 1996).

O teste de confiabilidade é necessário porque os desenhos são raramente perfeitos e porque os projetistas não podem estar constantemente 
atentos ou ser capaz de analisar, todas as prováveis causas de falhas de seus desenhos em serviço (O’Connor, 1991).

Há duas estratégicas básicas de desenvolvimento de testes que podem ser usadas para melhorar a confiabilidade de uma máquina (Schaedler, 2003):

- Test-Fix-Test (Testar-Corrigir-Testar):

- quando uma falha ocorre, o equipamento em teste é reparado e colocado fora do teste;

- as pecas falhadas são analisadas fora da máquina, sem impactar a programação do teste;

o assim, que os componentes reprojetados com melhor confiabilidade estiverem disponíveis, são instalados na máquina em teste. As modificações de projeto são incorporadas constantemente nos protótipos durante os testes.

- Test-Find-Test (Testar-Encontrar-Testar):

○ as deficiências do projeto são identificadas, mas as ações corretivas serão implementadas no final da fase de testes;

- a confiabilidade projetada não estabelece o fim dos testes, pois uma fase de teste adicional é necessária para verificar a eficácia das ações corretivas.

Em geral, durante a primeira fase do desenvolvimento do produto, a estimativa da Confiabilidade final do produto é chamado de objetivo da Confiabilidade. Para atingir esse objetivo, o produto deverá ser submetido a 
testes compreensivos e ações corretivas apropriadas deverão ser implementadas. Esse processo bem estruturado de encontrar problemas de Confiabilidade e monitorar a melhoria de Confiabilidade do produto através de sucessivas fases é chamado normalmente de crescimento da Confiabilidade (ReliaSoft 1998).

A norma MIL-HDBK-H 108 - Sampling Procedures and Tables for Life and Reliability Testing (Based on Exponential Distribution) - provê procedimentos e tabelas de distribuição exponencial para o teste de Confiabilidade e vida útil. Por sua vez; a norma MIL-HDBK-189 Reliability Growth Management estabelece fundamentos dos mais simples até análises técnicas mais detalhadas, incluindo conceitos e princípios de crescimento da Confiabilidade, vantagem de gerenciamento do crescimento da Confiabilidade (Reliability Std \& Handbooks).

A segunda edição da IEC 61014, publicada em Julho de 2003 (Ellis, 2003), descreveu o crescimento da Confiabilidade baseado na análise da Confiabilidade como: FMEA, teste de módulos e submontagem, bem como teste de protótipo e itens liberados. Contudo, a norma tem sido atualizada de acordo com a prática atual da indústria. O crescimento da Confiabilidade está sendo visto como um processo de projeto, não somente como um processo de teste e correção. Métodos analíticos e métodos de teste estão completamente integrados no esforço do projeto em aumentar a Confiabilidade durante a fase de desenho do produto.

O objetivo do teste de crescimento deve ser estimular falhas durante 0 teste de desenvolvimento, considerando o ambiente e condições em que o produto estará inserido e não forçar uma condição, nem métodos de reportar falhas, com o intuito de maximizar a chance de demonstrar que a especificação tem sido satisfeita. Como um programa honesto e aberto apresenta alta demanda de trabalho em equipe e integridade, enfatiza-se a importância do gerente de projeto entender o objetivo e estar no controle do programa de Confiabilidade (O' Connor, 1991). 
A curva da banheira mostra que, durante o período de mortalidade infantil dos componentes, a taxa de falha é considerada alta, quando comparada com o que ocorre no período de vida útil do componente (Dummer, 1997). Se os componentes ou subsistemas forem incorporados diretamente na linha de produção dentro de um equipamento complexo, o qual foi enviado diretamente ao Cliente, uma alta taxa de falha inaceitável deverá ser vivenciada durante as primeiras 100 horas. Com o intuito de minimizar esses efeitos, um procedimento conhecido como Burn-in, é freqüentemente empregado, em que o componente individual (circuito integrado, transistor, capacitor,etc) ou subsistema (circuito da base da impressora) são operados por centenas de horas sob condições ambientais levemente mais severas do que o normalmente encontrado quando operado em condição normal. $O$ efeito disso é induzir a ocorrência das muitas falhas precoces nos componentes ou subsistemas antes da integração dos mesmos no sistema. Esse é, obviamente, um custo de operação satisfatório, mas uma grande economia é possível devido à redução de requisitos de duplicidade de trabalho (fazer e refazer), no produto final, e também a satisfação do Cliente é mantida (Dummer, 1997).

Burn-in no produto final é possível, mas o diagnóstico e a duplicidade de trabalho para garantir a Confiabilidade, sob condições ambientais normais de trabalho, pode demandar um montante muito grande de dinheiro e um tempo muito mais longo do que se este teste fosse conduzido ao nível de componente.

A FIGURA 2.6 mostra a seqüência de diagnóstico de falhas, reparo ou substituição, classificação e (onde se aplica) investigação mais profundas e modificação corretiva. O mesmo processo geral deve ser aplicado onde a fonte de informação é um programa informal ou uma atividade tendo um objetivo primário diferente (BS EN 61014:2003). 


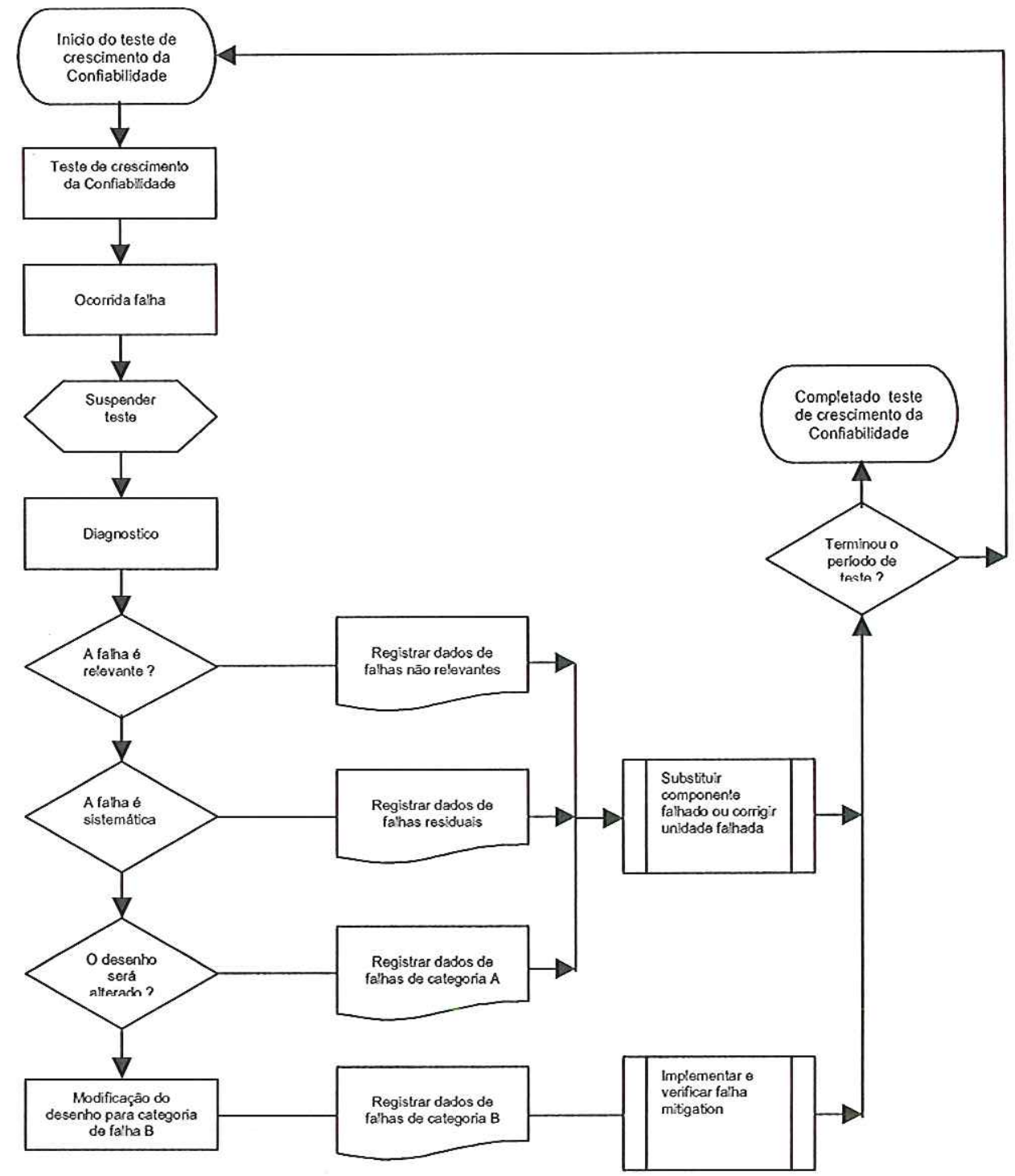

Figura 2-6 - Processo de crescimento da confiabilidade em teste - BS EN 61014:2003

\subsubsection{Teste de triagem de stress ambiental (ESS) e Burn-in}

O desenvolvimento de um programa de teste deve contemplar todas as principais variáveis ambientais, com as quais o produto estará se deparando, quando estiver em operação nas mãos do Cliente final. Normalmente estes testes são realizados nas fases do protótipo, piloto ou quando um problema grave específico está sendo analisado, porém, a não ser o custo envolvido, 
nada impede que testes deste tipo possam ser utilizados em análises de Confiabilidade ou durabilidade dos produtos em produção.

O objetivo principal dos testes de triagem de stress (ESS - Enviromental Stress Screening) é acelerar e estimular o aparecimento das falhas em componentes, conjuntos ou produto finais. O estímulo é baseado nos fatores comuns, que estes componentes estarão enfrentando, quando o produto estiver desempenhando a atividade pela qual foi concebido.

Burn-in é o nome dado para o processo para estimular falhas em componentes e conjuntos eletrônicos defeituosos, acelerando os stress que causarão defeitos nas peças que estão falhando, sem afetar outras peças boas. O termo Environment Stress Screening (ESS) é também utilizado em conjuntos. (O'Connor, 1991).

A diferença entre o Burn-in e o ESS é quanto ao tempo de aplicação do stress e ao nível de aplicação destes (Vollert Jr, 1996). O Burn-in tem o tempo de aplicação maior do que o do ESS e com os stress aplicados dentro do especificado, já para o ESS os stress são aplicados além dos limites especificados pela equipe de projeto.

\subsection{Previsão das falhas do produto}

A predição da Confiabilidade é definida como o processo de estimar quantitativamente a Confiabilidade de um projeto, a fim de verificar se este irá atender aos requisitos da Confiabilidade (Bérgamo, 1997). Essa estimativa é feita bem no início das atividades de um projeto, sem a existência de protótipos. Isso pode se traduzir em diminuição significativa de custos. É lógico que a predição em si não contribui para a melhoria da Confiabilidade do sistema. O valor da predição está na informação gerada e no uso que é feito dela. Através da utilização de técnicas de predição, pode-se, entre outras 
coisas, identificar áreas/pontos no sistema que requerem melhorias, ou estimar os custos de manutenção durante o período de garantia

A atividade de previsão determina a Confiabilidade de software futura baseada em métricas de software e medidas disponíveis (Silva Filho, 2003). Dependendo do estágio de desenvolvimento, a previsão pode envolver diferentes técnicas como:

- Quando os dados de falhas estão disponíveis - por exemplo, o software encontra-se em testes ou no estágio operacional. Neste caso, as técnicas de estimulação podem ser usadas para parametrizar e verificar os modelos de Confiabilidade de software, os quais realizam previsão de Confiabilidade de software futura;

- Quando os dados de falhas não estão disponíveis - por exemplo, quando o software ainda se encontra na fase de projeto ou implementação. Neste caso, as métricas obtidas do processo de desenvolvimento de software e as características do produto resultante podem ser utilizadas para determinar a Confiabilidade de software durante testes.

Em todo desenvolvimento de projeto e lançamento de um novo produto ou mesmo na atualização de um produto corrente, a Empresa sempre busca ter uma maior Confiabilidade de campo do que a prevista no início do programa. Porém esse resultado vai depender muito dos recursos tecnológico, financeiro e humano a serem destinados ao programa. Contudo determinar o diferencial da causa raiz das falhas é o primeiro passo para buscar uma melhoria das estimativas da Confiabilidade.

O processo de projeto é a etapa do ciclo de vida que faz uso das informações organizadas na etapa do planejamento do desenvolvimento para transformar em sistema técnico. O processo de projeto [Back/Forcellini1997, Ogliari 1999, Fonseca2000] pode ser definido como um conjunto de atividades 
de síntese e de análise que se desenvolve, basicamente, em quatro fases: fase informacional em que são sistematizadas as informações, fase conceitual em que se gera o conceito ou conceitos relativos ao produto, fase preliminar que avalia o conceito gerado e produz análise preliminar, e a fase detalhada em que é definida toda a comunicação entre os parâmetros necessários para as etapas de fabricação e uso/descarte. Em cada uma das fases considera-se o atributo da Confiabilidade de forma que possa ser mantido nas outras etapas do ciclo de vida (Dias, 2003).

A FIGURA 2.7 apresenta a Confiabilidade nas diversas fases do ciclo de desenvolvimento do produto.

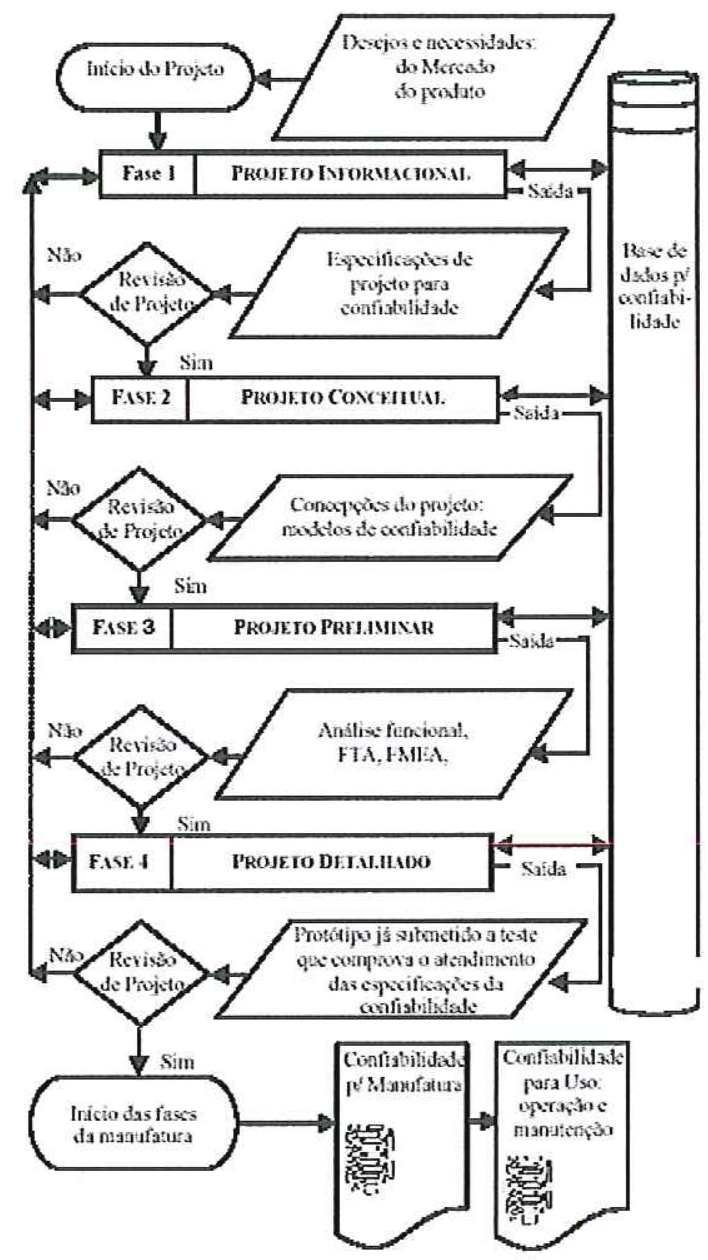

Figura 2-7 - Sistemática para a consideração da Confiabilidade no processo de projeto (Dias, 1999). 
A pesquisa realizada por Miller \& More (1991), através de um questionário que pedia aos especialistas da Confiabilidade para responder sobre a diferença da Confiabilidade (campo x prevista pelo programa), apontou apenas seis fatores como sendo estatisticamente significantes a este diferencial (Vollertt Jr, 1996). As opiniões dos especialistas estão classificadas abaixo, por ordem decrescente de importância:

- fatores relacionados ao projeto:

- a seleção inapropriada de peça e componente contribuía severamente para os problemas de Confiabilidade, e o fator principal para a má seleção é o pobre entendimento do ambiente operacional do sistema.

- precisão de dados:

- a maioria dos problemas está na área de definição dos dados, e na coleta desses dados. Para a definição dos dados, o maior problema está na classificação da falha e nos procedimentos de pontuar a severidade da falha. Quanto à coleta de dados de falha, há uma falta de incentivo e de motivação para uma classificação precisa da falha por parte dos coletores de dados, e a coleta dos dados é usada mais com o propósito de manter uma documentação do que coletar dados precisos de Confiabilidade.

- processo de manufatura:

- os problemas primários podem ser classificados dentro das áreas de qualidade e manufatura. Um projeto robusto poderia 
resolver a maioria dos problemas de manufatura. Qualidade do produto, por outro lado, depende fortemente da Empresa suportar um programa de gerenciamento total da qualidade.

\section{- técnica de previsão:}

- os problemas de previsão da Confiabilidade foram atribuídos às técnicas e hipóteses utilizadas pela norma MIL-HDBK-217. A deficiência da norma é quanto à não-representatividade dos ambientes operacionais. Um outro problema com relação à previsão é quanto à aplicação imprópria de modelagem ou simulação da Confiabilidade.

- foco gerencial a curto prazo:

- os gerentes estão mais preocupados com os benefícios de curto prazo do que com os de longo prazo. A gerência de curto prazo é o maior gargalo para alcançar os níveis de Confiabilidade que são desejados pelos Clientes.

\section{- fatores ambientais:}

- a maioria dos problemas é devido ao mau entendimento e à má interpretação dos ambientes operacionais do produto. Isto se deve à dificuldade de predizer com certeza os ambientes em que o produto irá operar. Outro problema é que Confiabilidade é tipicamente predita com base em testes anteriores no nível de componentes e/ou subsistemas, com pouca consideração às interfaces e integrações do sistema como um todo. 


\subsubsection{Melhorando o processo de previsão}

O processo de inferência Bayesiana utiliza uma distribuição prévia para prever a Confiabilidade em que com dados reais de falha, uma função heurística é determinada para gerar uma distribuição posterior, através de um processo interativo, em que cada estimativa posterior se torna uma melhor estimativa da verdadeira distribuição de falha, e pode ser implementado com ou sem a ajuda de um computador (Vollertt Jr, 1996).

A distribuição prévia é uma estimativa da população. Até que falhas ocorram, a distribuição prévia é uma estimativa da distribuição de falha. A ocorrência de falha constitui dados de amostras da verdadeira distribuição de falhas. Por combinar os dados da distribuição prévia com os dados de amostras, uma estimativa posterior é determinada.

A estimativa da distribuição posterior é uma melhor estimativa do que a distribuição prévia, porque ela leva em consideração dados reais de ocorrência de falha, e é melhor do que somente dados de amostras, pois não permite que dados de amostra pequenos influenciem a estimativa da população. A figura 2.8 mostra o procedimento para gerar a distribuição posterior, em que cada distribuição posterior se torna a distribuição prévia da distribuição posterior seguinte, quando novos dados da distribuição real são encontrados.

A distribuição prévia é gerada através das previsões da Confiabilidade, que é uma tentativa de estimar a verdadeira Confiabilidade através de modelos, dados genéricos, informações colaterais, intuição e julgamento de engenharia.

A distribuição posterior é derivada, por combinar a distribuição prévia com a da amostra de dados reais, por meio de uma função combinada. (FIGURA 2.8). 


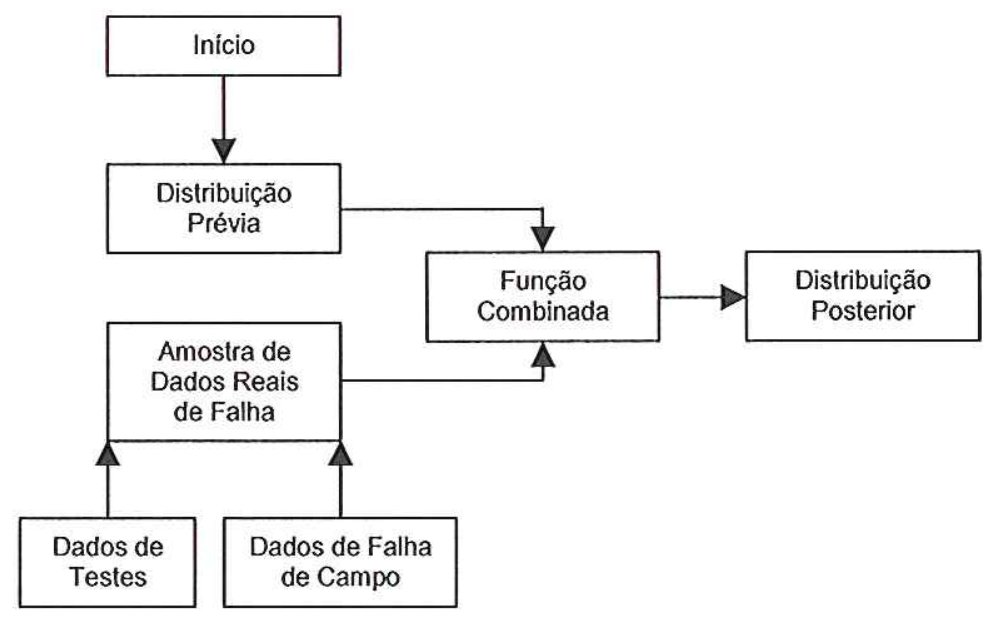

Figura 2-8 - Processo para atualização da melhor estimativa da Confiabilidade, Giuntini (1993)

\subsection{A importância dos dados de Confiabilidade de campo}

Produtos recém-lançados ou recém-atualizados que normalmente apresentam falhas no início de sua vida útil (falhas precoces), têm, como causas principais na maioria das vezes, razões financeiras, tempo de desenvolvimento menor do que o requerido, pressão do mercado, seja, do Cliente ou do concorrente, dentre outras.

Essas falhas normalmente são causadas por modos de falhas que não foram testados nas fases anteriores do processo, de modo que pudessem ser previstas e, conseqüentemente, evitadas. A Empresa tem que utilizar a Revenda para obter a maior e mais precisa informação a respeito da falha ocorrida, a fim de melhorar imediatamente o produto em fabricação.

Os dados de Confiabilidade obtidos no campo podem ser utilizados como termômetro, a fim de medir a satisfação do Cliente em relação ao produto adquirido. Baseado nas informações, a Empresa poderá corrigir os problemas nos produtos atuais ou na próxima fase de atualização. É de suma importância para a Empresa que os dados de campo sejam comunicados o mais rápido possível, ou seja, de preferência, assim que o problema ocorrer, o Cliente 
deverá entrar em contato direto com a Revenda. Essa, por sua vez, deverá obter o máximo de detalhes possível junto ao Cliente, inclusive informações a respeito de fatores ambientais, condições de uso e sentimento do Cliente, a fim de poder fornecer a Empresa dados completos, confiáveis e precisos a respeito do problema e das variáveis em que o produto esta inserido.

Os dados de Confiabilidade de campo são obtidos através de contato direto da Revenda junto ao Cliente, através de pesquisa de satisfação de Clientes ou através dos representantes de serviço da Empresa em visitas ao Cliente.

\subsection{Limitação dos dados de Confiabilidade de campo}

Segundo Baxter \& Tortorella, na prática os dados analisados são freqüentemente os de campo, que não são sempre reunidos para o propósito de análise estatística, e são freqüentemente incompletos, de alguma forma. Os fatores que fazem os dados de campo incompletos são (Vollertt Jr, 1996):

- tempo incompleto de vida: normalmente a Empresa coleta dados de taxa de falha de um produto, incluindo, neste tempo, períodos em que o sistema não estava em uso, como o tempo de armazenamento, tempo até o Cliente decidir fazer o reparo no produto, etc. Isto causa um mascaramento da verdadeira taxa de falha do produto ou componente;

- mascaramento: um sistema, quando contém vários subsistemas, e cada subsistema vários componentes, quando ocorre uma falha, o pessoal que faz o reparo freqüentemente substitui um módulo inteiro (subsistema), sem realizar uma análise do componente danificado contido neste módulo. Com isso, só se conhece o dado do módulo 
falhado ou falho e não qual componente e suas causas. Isto ocorre muito com produtos eletrônicos;

- ambientes desconhecidos: a distribuição do tempo de vida de um componente é afetada pelos ambientes em que o componente está operando. A taxa de falha aumenta sob condições adversas de stress, tal como temperatura, voltagem, umidade, etc. Normalmente não se colhem dados sobre o ambiente operacional do componente falhado, apenas se possui conhecimento dos ambientes de um grupo de componentes.

- por último, mas não menos importante que os anteriores, podemos citar que os dados são coletados por diversas pessoas de diferentes níveis de conhecimento técnico, capacidade e motivação, o que afeta significativamente os resultados. Com o intuito de minimizar este efeito, formulários padrões com perguntas básicas e o não pagamento da garantia sem a apresentação do formulário devidamente preenchido, podem minimizar os erros e facilitar o entendimento do que está sendo realizado.

\subsection{Feedback do campo}

O "feedback" do Cliente relativo ao produto adquirido é uma excelente ferramenta que a Empresa possui, caso a mesma seja utilizada apropriadamente, ou seja, com o objetivo de entender a reclamação / solicitação / reivindicação e transformá-la em melhoria do produto. Porém, para que a Empresa tenha bons resultados, as informações provenientes do feedback necessitam ser completas, claras e detalhadas. Informações imprecisas ou incompletas poderão levar a Empresa a não trabalhar para implementar mudanças no processo / produto ou poderão até direcionar alterações incorretas, caso não seja conhecida a real causa raiz da falha. 
Sampson diz que o feedback de Clientes é um importante elemento no gerenciamento da qualidade (Cardoso, 2001). O investimento no sistema de feedback de Clientes pode gerar retornos consideráveis. Embora o sistema de feedback de Cliente possa promover a qualidade dirigida ao Cliente, ele é normalmente utilizado apenas como um gerenciamento de reclamações de Clientes.

O feedback de campo também pode ser usado como um "termômetro" em beneficio da Empresa, visto que ele poderá medir a satisfação do Cliente em relação ao desempenho do produto, disponibilidade de peças de reposição, qualidade do serviço prestado pela assistência técnica, dentre outros aspectos. Atualmente a grande maioria das Empresas está focada no atendimento ou superação das expectativas do Cliente. Assim sendo, a opinião / reclamação ou sugestão de melhoria oriunda do Cliente, seja ela feita de maneira informal ou formal, são de suma importância para o desempenho da Empresa no mercado atual, bem como para o estabelecimento de estratégia da Empresa para médio e longo prazo.

Uma metodologia para um eficiente feedback de campo, supondo que os dados de campo sejam completos e confiáveis, foi proposta por Brall em 1994, FIGURA 2-9. Nessa proposta, o sistema recebe as informações das falhas ocorridas no campo, bem como as falhas coletadas dentro da fábrica. Uma vez identificados as falhas repetitivas, seja no campo ou na fábrica, a Empresa deverá abrir ações corretivas para que elas sejam implementadas tanto nos produtos correntes como nos novos (Vollert Jr, 1996). 


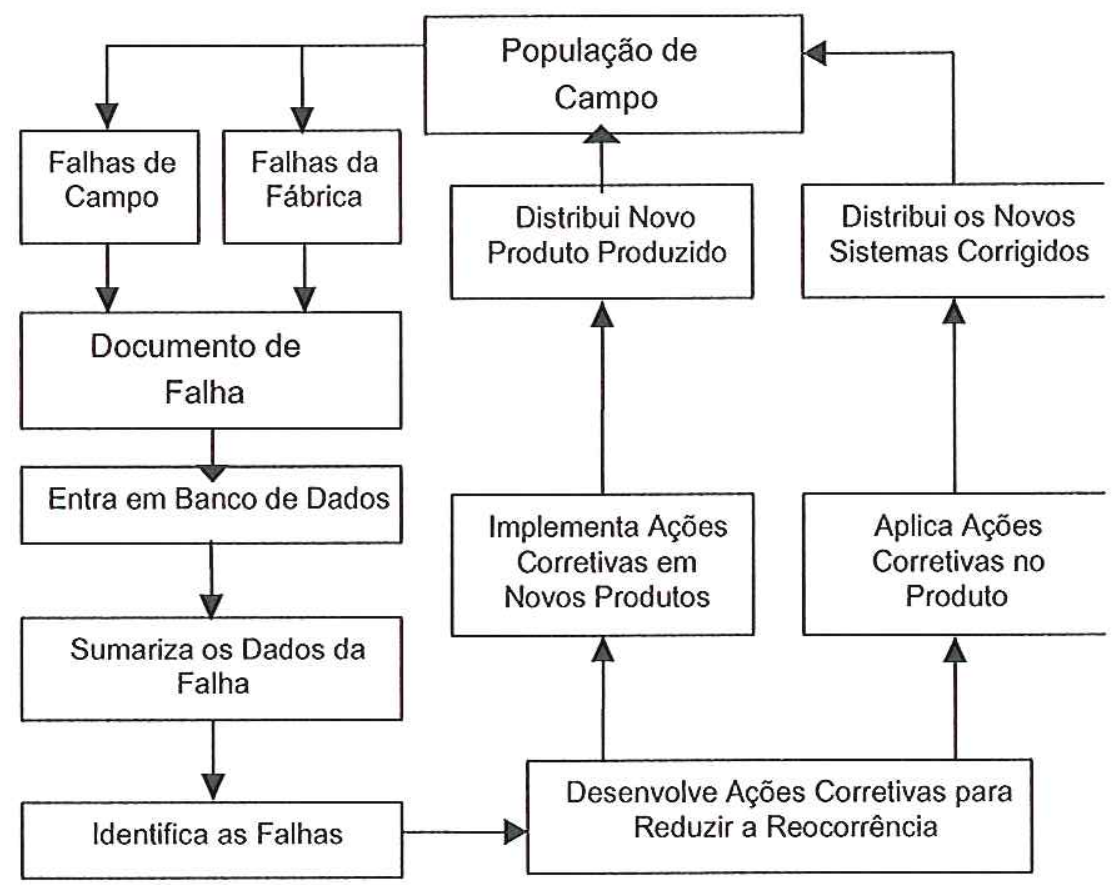

Figura 2-9 - Sistema de Feedback de Campo e Ações Corretivas, Brall (1994)

\subsection{Quais dados de Confiabilidade de campo são importantes para a Empresa}

Para uma Empresa de automóveis, (Majeske \& Herrin, 1995), os dados que normalmente são enviados contém as seguintes informações: número de identificação do veículo, dados do reparo como peças trocadas, a parte que causou a falha (freqüentemente é registrado como sendo um subsistema e não o componente), o modo de falha (exemplo: curto circuito na parte elétrica), subsistema afetado pela falha (exemplo: ignição, luzes, etc).

Porém, pode-se acrescentar outras informações que contribuirão muito e são essenciais, tais como:

- fatores ambientais; 
- fatores operacionais;

- sintomas das falhas;

- diagnósticos observado durante a correção de falha;

- índice de Confiabilidade do produto.

De posse destas informações a Empresa poderá quantificar, agrupar e priorizar as falhas, de modo a poder direcionar seus esforços e atacar realmente os principais problemas, os quais deverão estar classificados numa ordem do mais grave para o menos, através de ações corretivas.

\subsubsection{Fatores ambientais}

Influências ambientais podem ter caráter mecânico, físico ou biológico e podem deteriorar o produto. Com isso, o produto poderá se tornar inseguro, ter uma vida útil menor do que o esperado, comprometendo a Confiabilidade do produto perante o Cliente.

Os efeitos das influências ambientais impactam fortemente no material e, por essa razão, as características dessas influências têm que ser especificadas para cada tipo particular de material, em muitos casos envolvendo deteriorização química e biológica.

A influência do ambiente pode ser classificado como permanente, variável e acidental. Exemplo:

- influência permanente é o efeito químico do cloreto da água do mar no concreto; 
- influência variável é o efeito da umidade na resistência da madeira.

Os principais fatores ambientais que afetam a maioria dos produtos são (O’Connor, 1991):

- temperatura;

- vibração;

- umidade;

- poeira;

- ambiente salino;

- idade do lubrificante ou contaminação deste;

- impacto;

- corrosão;

- interferência elétrica

Além dos fatores acima citados, a Empresa deve ficar atento a fatores ambientais inerentes de um determinado lugar que podem afetar um determinado produto, como por exemplo, para Empresas de máquinas de terraplenagem, outros fatores que podem afetar o desempenho ou vida útil são:

- tipo de terreno; 
- abrasividade;

- severidade da aplicação;

- altitude.

Baseado no exposto acima, é fundamental, para a Empresa, que, durante a fase de coleta de dados pela Revenda, sejam obtidas informações também da região em que ocorreu a falha e as características ambientais do meio onde estava sendo operado o seu produto, a fim de facilitar a investigação da falha e ajudar na sua solução.

\subsubsection{Fatores operacionais}

Fatores operacionais estão relacionados diretamente ao uso do produto. A Empresa, através do manual de manutenção e operação, do manual de produção, do corpo técnico qualificado da Revenda, fornece ao Cliente os requisitos, especificações e recomendações necessárias para que o mesmo venha a obter a melhor performance do produto a um custo operacional compatível com a aplicação. Isso somente será possível, se o produto for utilizado exatamente para a finalidade a que foi desenvolvida e as recomendações de manutenção sejam seguidas adequadamente. Alguns fatores operacionais são:

\subsubsection{Mau uso ou uso indevido do produto}

O mau uso ou uso indevido do produto, pelo Cliente, poderá trazer problema ao produto, tanto operacional como econômico, visto que não é paga 
garantia ao Cliente no caso de comprovação de mau uso, seja ele, intencional ou não. É considerado mau uso ou uso indevido do Cliente:

- não operar o produto adequadamente e na aplicação para a qual foi projetado;

- não manter o produto em condições adequadas de trabalho;

- não comunicar a Revenda, assim que um problema for percebido pelo operador e/ou mecânico;

- não realizar a manutenção, reparo de itens em garantia que possam causar a garantia de outros itens que poderiam ser evitados (por exemplo: não seguir o intervalo de manutenção recomendado pela Empresa; usar a máquina para outra aplicação para a qual não foi recomendada ou desenvolvida).

\subsubsection{Taxa de uso do produto}

Esse fator também é muito importante a ser considerado pela Empresa, principalmente porque, dependendo da utilização do produto, quantidade de horas de uso por dia, o Cliente poderá exceder em muito as estimativas iniciais feitas pela Empresa. Esse fator pode ser o causador de muitas falhas do produto junto ao Cliente, caso não tenha sido considerado durante a fase de desenvolvimento.

Um bom exemplo do fator de utilização de um produto é a comparação entre um carro adquirido por Cliente comum, o qual ira utilizá-lo por poucas horas diárias ou semanais e um carro mesmo modelo e com os mesmos opcionais, adquirido por um taxista, o qual ira utilizá-lo durante por muitas 
horas diárias. Normalmente, o teste feito no produto pela Empresa leva em consideração o número de horas até a falha, e a conversão do número de horas até a falha para meses ou ano, só pode ser feita se a Empresa tiver plena noção do fator de utilização a que será colocado o produto.

Algumas Empresas podem utilizar os dados coletados com os produtos anteriores para estabelecer o fator de uso dos produtos futuros. Porém outras Empresas não dispõem de tal sistema e têm muita dificuldade de medir a taxa de uso do produto com precisão. Sendo assim, este fator passa a ser um problema para a Empresa.

\subsubsection{Taxa de potência do produto}

Um outro fator importante é a taxa de potência (Vollertt Jr, 1996). Ela está influenciada pela potência utilizada pelo usuário para operar um produto. Normalmente os produtos são oferecidos com uma certa faixa de potência a serem operados. Por exemplo, um liquidificador possui três velocidades de operação, um condicionador de ar possui opções de alta média e baixa temperatura, e um automóvel possui opções de velocidades.

Caso o Cliente opere o produto sempre na máxima potência, ou velocidade máxima, ou com carga máxima, poderá causar uma maior ocorrência de falhas, devido ao uso constante no seu limite máximo, do que o Cliente que fica alterando o ritmo, velocidade, carga do produto. Este, sem dúvida, é um fator difícil de ser previsto pela Empresa, principalmente se o produto oferecido é vendido em diferentes mercados mundiais. 


\subsubsection{Sintoma da falha}

A coleta de informações referente aos acontecimentos que antecederam a falha é muito importante. O sintoma da falha observado e vivenciado pelo Cliente, por mais insignificante que possa parecer, é extremamente importante para a Empresa, pois, a partir destas informações, as investigações a respeito da causa raiz podem ser facilitadas e/ou seguir o caminho correto para a solução definitiva da falha.

Segundo Porto, 1982, um sintoma bem investigado e bem compreendido abre caminho para um exame físico objetivo, em que os dados mais importantes são (Vollert Jr, 1996):

- época em que ocorreu o início da falha ou que o sintoma apareceu;

- o modo como a falha ocorreu:

- gradativamente;

- subitamente.

- os fatores ou situações que funcionam como desencadeantes do sintoma;

- a duração que é estabelecida conforme a data de início;

- as características do sintoma na época em que houve o início:

o intensidade;

- localização. 
- evolução do sintoma:

- modificações observadas.

- situação do sistema no momento atual.

\subsubsection{Diagnóstico observado durante o reparo}

O diagnóstico bem feito é essencial tanto para o direcionamento do mecânico da Revenda, a fim de que ele consiga sanar a falha definitivamente ou realizar um reparo paliativo, bem como para a Empresa, pois através do diagnóstico, muitas informações importantes podem ser coletadas a respeito dos sintomas apresentados pela falha antes dela vir a acontecer, a conseqüência da mesma, o impacto junto ao Cliente. Essas informações em muito auxiliam a Empresa na tomada de decisão a respeito de que ações deverão ser implementadas para sanar a falha, bem como melhorar o projeto ou o processo do produto.

\subsection{5 Índices de Confiabilidade}

Os índices de Confiabilidade são utilizados para, a partir de uma base estabelecida previamente, poder ter parâmetros comparativos para poder avaliar o desempenho do produto atual, a fim de avaliar sua performance e estabelecer objetivos futuros tanto para o produto corrente como para novos outros. Os principais índices de Confiabilidade utilizados são :

- MTBF (Mean time between failure) - aplica-se para itens reparáveis e significa o tempo médio de falhas sucessivas do mesmo (ex: se um 
item apresenta 5 falhas durante um período de 1000 horas, o tempo médio entre as falhas é de 200 horas). Em outras palavras, o MTBF indica quanto o produto é confiável no período de sua vida útil;

- MTTR (Mean time to repair) - é o tempo médio que um determinado item leva para ser reparado;

- taxa de falha - é o número médio de falhas ocorrida dentro de uma população, é obtida dividindo o número total da vida das unidades (população) durante um particular intervalo medido, sob certas condições.

\subsection{Conclusão}

Esse capítulo foi dedicado à apresentação dos fatores envolvidos com a Confiabilidade e a tarefa da área de Confiabilidade nas diversas fases do desenvolvimento do produto. Mostrou-se também a importância dos dados obtidos do campo, os tipos de falhas e as influências que afetam a Confiabilidade. Apesar de todo o exposto neste capítulo, na verdade o que importa ao Cliente final é que o produto que ele está comprando desempenhe a função para a qual foi desenvolvido, com uma durabilidade conforme anunciada e a um preço razoável. 


\section{CAPITULO III}

\section{Estudo de caso}

\subsection{Introdução}

Os revendedores são uma extensão da Empresa e são os responsáveis por todo e qualquer serviço após o produto ter deixado a Empresa. Sendo assim pode-se dizer que os revendedores são a voz e os olhos da Empresa, visto que eles são um dos elos de comunicação mais importantes entre o Cliente e a Empresa.

Durante o período de garantia do produto, a Revenda é a responsável para efetuar os reparos nos produtos, sendo os custos dos mesmos divididos entre a Empresa (material) e a própria Revenda (mão-de-obra). Após o período de garantia, o Cliente é o responsável pelos gastos com o reparo do produto, ficando a seu critério a realização do reparo na Revenda ou não, exceto em casos de "recall", em que, na maioria das vezes, o Cliente não arca com custo, e o reparo tem que obrigatoriamente ser feito em uma das Revendas.

A Revenda é a principal responsável por coletar, filtrar e alimentar a Empresa a respeito da saúde do produto, seja durante o período de garantia, bem como em toda a extensão da vida útil do produto. É baseado nestas informações que se faz o monitoramento do nível de Confiabilidade do produto e se necessário, ações de contenção e correção são implementadas pela Empresa. 


\subsection{Justificativa da escolha}

A escolha desta Empresa para a realização desta dissertação foi em função da mesma pertencer a um ramo da indústria automobilística, na qual a busca pela excelência da qualidade e melhoria contínua faz parte do seu dia a dia, uma vez que a mesma sofre a pressão da competição globalizada. Sendo assim, o investimento em pesquisa e desenvolvimento de novos produtos visando a atender as legislações futuras (emissões, ruídos, qualidade, ambiental, social) é parte integrante de sua organização.

A Revenda é a primeira a conhecer os defeitos, falhas que ocorrem com o produto no campo. Após o diagnóstico e detecção dos mesmos, realiza as correções necessárias e, caso não exista correção definitiva, aplica um reparo emergencial (ação interina), até que o reparo definitivo seja estabelecido. Logo após a Revenda informa a falha a Empresa, para que as devidas ações sejam tomadas, quer seja para os produtos futuros ou para aqueles que sofreram ações emergenciais. Também cabe à Revenda fazer o acompanhamento dos produtos após uma correção ter sido implementada, a fim de se certificar de que a solução adotada foi correta e duradoura.

A escolha desta Revenda se deu em função de ser a maior no Brasil e pelos dados disponíveis existentes junto à mesma.

\subsection{Metodologia}

O método de pesquisa para a realização deste estudo de caso, foi conduzido da seguinte maneira: 
- análise dos manuais de manutenção e operação;

- análise do manual de rendimento dos produtos;

- entrevista com o pessoal da área de suporte ao produto da Empresa;

- entrevista com o pessoal da área técnica da Revenda;

- análise de dados do sistema de registro de falhas utilizado pela Revenda e Empresa.

\subsection{Dados sobre a Revenda}

Neste tópico será apresentada uma visão geral da maior Revenda nacional e uma das maiores a nível mundial da Empresa. A Sociedade de Tratores e Equipamentos S. A. - Sotreq é uma Empresa de capital nacional fundada no dia 13 de outubro de 1941. Revendedora exclusiva dos produtos e serviços Caterpillar, atua nos Estados do Rio de Janeiro, São Paulo, Minas Gerais, Goiás, Mato Grosso, Mato Grosso do Sul, Tocantins, Pará, Amazonas, Espírito Santo, Amapá, Rondônia, Acre, Roraima e no Distrito Federal.

Essa Revenda possui a matriz no Rio de Janeiro e mais 35 filiais no território brasileiro, conforme mostra a FIGURA 3-1. Ela atua na comercialização de máquinas e motores, bem como na assistência técnica, pós venda. Sua força de trabalho é de 2.000 funcionários, com uma área construída de 61.352 metros quadrados dentro de uma área disponível de 433,438 metros quadrados. 


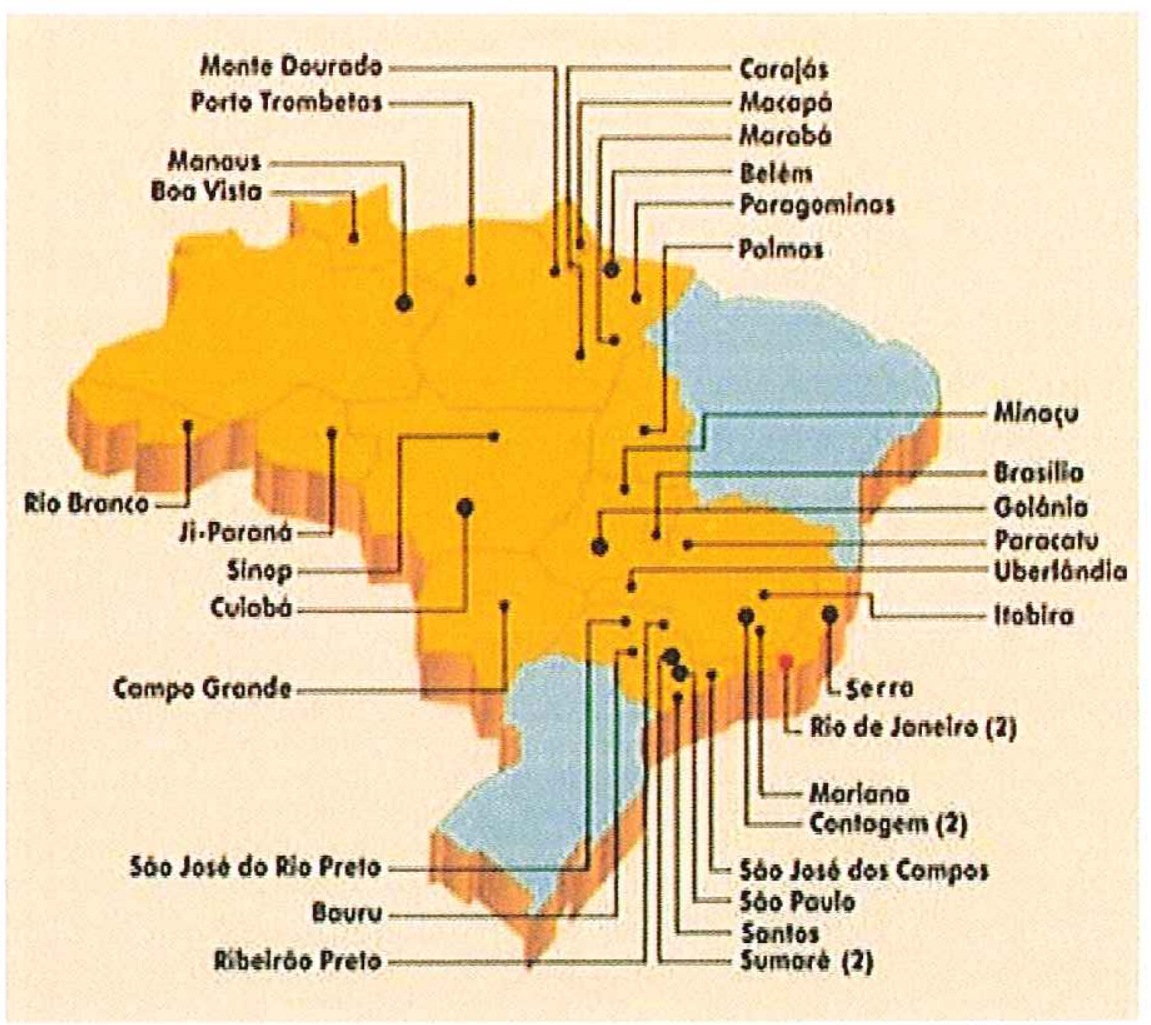

Figura 3-1 - Localização das Revendas Sotreq

Nas oficinas da Revenda, cerca de 300 mecânicos treinados e atualizados, na tecnologia da Empresa trabalham apoiados por ferramentas especializadas, aparelhos de diagnóstico, literatura técnica e sistemas de informação computadorizados, para manter custos econômicos e assegurar qualidade e produtividade, segundo padrões estabelecidos pela Empresa.

As reformas de máquinas, componentes e subconjuntos nas oficinas da Revenda passam pelas etapas de pré-lavagem, desmontagem, lavagem, metrologia, montagem, testes e pintura, com todos os serviços baseados em critérios periodicamente avaliados pela Empresa. Máquinas operatrizes de usinagem e de solda também integram a estrutura das oficinas mecânicas da Revenda, inclusive seção destinada à reforma de motores de arranque e alternadores, testados em bancadas próprias. 
Mecânicos especializados, com muitos anos de treinamento e experiência prática em oficinas da Revenda, atendem as necessidades de manutenção preventiva e corretiva dos Clientes, no local onde operam.

Todos dispõem de veículos equipados com ferramentas, sistemas e literatura técnica, disponibilizados pela Revenda, como recurso para o rápido diagnóstico de falhas de componentes e subconjuntos das máquinas que atendem.

Uma parte da equipe presta serviços a Clientes frotistas como mineradoras e empreiteiras de obras públicas e privadas, residindo no próprio local, além de atuar nos contratos de manutenção preventiva firmados com Empresas proprietárias de poucas máquinas.

A assistência externa ainda inclui o serviço de controle de contaminação, executado por técnico da Revenda, que utiliza um conjunto portátil desenvolvido e disponibilizado pela Empresa, que permite a verificação segura de contaminantes sólidos em óleos lubrificantes, detectando indicações de falhas potenciais nos produtos.

A Revenda também oferece outros tipos de serviço como:

- $\mathrm{CHS}$ - Serviço Especializado de Hidráulica:

- mantém a alta produtividade dos produtos através do monitoramento e gerenciamento dos sistemas hidráulicos, evitando paradas inesperadas e altos custos de reparos;

- inspeções programadas para garantir alta eficiência. Uma perda de eficiência de até $20 \%$ não é observada pelo operador. Isto corresponde a 1 dia de produção em 5 dias de trabalho. O CHS não permite a falha dos componentes 
hidráulicos e estende a vida do óleo hidráulico. O Serviço é um completo programa de inspeção, executado por um técnico, que faz monitoramento constante nos componentes do sistema hidráulico. O programa inclui controle de contaminação, testes de desempenho e diagnósticos e análise dos fluidos pelo S.O.S.

- Service Plus:

- o Service Plus é um serviço que contempla as manutenções preventivas e reparos corretivos executados nos equipamentos novos até o período anterior às reformas gerais de grandes componentes, quando é necessário avaliar as necessidades da produção e os investimentos para se obter nova vida útil. Isso garante uma frota sempre bem conservada, produtiva, confiável e com alta liquidez. O Service plus cobre:

- manutenções preventivas a cada 250 horas, incluindo TODOS os itens do plano de manutenção recomendado pela Empresa, com custos de mãode-obra, peças e despesas de viagens do técnico da Revenda;

- inspeções a cada 250 horas, intercaladas com as preventivas, também com custos de mão-de-obra, peças e despesas de viagens incluídas;

- manutenções corretivas, de acordo com a necessidade, com custos de mão-de-obra, peças e despesas de viagens incluídas; 
- análise de todas as informações da manutenção para a tomada de decisões, juntamente com o Cliente;

- gerenciamento das pendências utilizando-se "janelas" de oportunidades;

- diagnósticos das falhas utilizando aparelhos, ferramentas e literaturas especializadas, com custos de mão-de-obra e despesas de viagens incluídas.

- ISA - Acordo de Inspeções Programadas:

- no gerenciamento de sua frota, o Cliente pode contar com o suporte técnico da Revenda, através de visitas programadas, para acompanhamento das manutenções visando à melhor programação dos reparos e redução de custos.

- EPP - Plano de Proteção do Equipamento:

- na compra de um produto novo, o Cliente diminui seus riscos estendendo a cobertura em garantia para todo o Trem de Força (motor, conversor de torque, transmissão, caixa de transferência, diferenciais, comandos finais, comandos de giro e tandens).

- PMP - Programa de Manutenção Preventiva:

- protege o investimento do Cliente através de Manutenções Preventivas realizadas corretamente e em intervalos 
determinados pelo Manual de Manutenção da Empresa. Com estes serviços realizados no local de operação, o Cliente maximiza a disponibilidade e minimiza os custos de operação. A Revenda também oferece o PMP Plus que é uma modalidade de PMP em que o Cliente ainda conta com uma cobertura em garantia de 24 meses para todo o Trem de Força.

- SED - Serviço Especializado de Diagnose:

- possibilita o monitoramento em tempo real de todas as máquinas. Como principais benefícios deste serviço, tem-se a Confiabilidade nas medições e garantia de um resultado mais preciso. Porém, como um serviço especializado, tem uma aplicação restrita aos casos que não podem ser resolvidos diretamente pelo mecânico, sem ajuda de um equipamento eletrônico (dataview - uma espécie de armazenador de dados), ou para dirimir dúvidas quanto ao diagnóstico

\subsection{Como a Empresa avalia o serviço da Revenda}

A organização deve monitorar informações relativas à percepção do Cliente sobre se a organização atendeu aos requisitos do Cliente (ABNT NBR ISO 9001:2000). Os métodos para obtenção e uso dessas informações devem ser determinados.

Após seis meses de venda do produto ao Cliente, a Empresa envia uma pesquisa com o intuito de colher informações diretas, tanto sobre o produto como o atendimento prestado pela Revenda. Essa pesquisa é denominada de Pesquisa de Satisfação de Cliente. Após o recebimento da mesma, os dados 
são registrados, analisados em equipe (multifuncional), normalmente conduzido pela equipe de Introdução de Novos Produtos. Caso necessário, ações corretivas são colocadas em prática com o intuito de solucionar as falhas, seja de caráter de projeto, processo ou mesmo de serviço da Empresa ou da Revenda. Após as devidas ações, o Cliente é comunicado a respeito da solução implementada.

\subsection{Tarefas exigidas pela Empresa}

As atividades a serem realizadas pelos revendedores são tão importantes quanto as realizadas dentro das dependências da Empresa. É devido a isso que o revendedor é considerado a extensão da Empresa, ou a "face da Empresa" junto ao Cliente. Abaixo estarão descritas as principais atividades relacionadas à parte técnica e garantia:

- entregar os produtos ao Cliente:

- montar os acessórios, os quais foram enviados desmontados, para evitar problemas de transportabilidade, antes da realização da inspeção de pré entrega;

- inspeção de pré-entrega - é uma inspeção geral realizado, no produto, a fim de detectar algum problema, seja de caráter visual, funcional ou operacional, antes que o produto seja entregue ao Cliente.

Todas as falhas encontradas durante as atividades são comunicadas a Empresa através de um sistema informatizado ("on line"), em que toda a rede de revendedores e todas as fabricas da Empresa estão interligadas, facilitando o rastreamento e monitoramento das falhas, através de incidências ou de valor de garantia. 
- atender as reclamações do Cliente:

- toda reclamação ou necessidade de informação do Cliente flui, na Revenda, através do comunicador técnico, o qual é o responsável por prover ações imediatas, a fim de atender as necessidades do Cliente.

- disponibilizar mecânico de imediato;

- prover diagnóstico a respeito da falha;

- prover soluções emergenciais, a fim de que o equipamento volte à operação, sem ocasionar outras falhas ou agravar a diagnosticada;

- após receber o diagnóstico do mecânico, comunicar imediatamente a Empresa as falhas encontradas, através do sistema SIMS, a fim de que a Empresa possa corrigir as falhas em outros possíveis produtos ou trabalhar na melhoria do componente ou conjunto;

- solicitar ajuda a Empresa, caso não consiga resolver as falhas através da literatura disponibilizada pela Empresa, a fim de atende as necessidades do Cliente;

- aplicar os programas de campo solicitado pela Empresa:

o o consultor técnico é responsável por:

" comunicar ao Cliente a necessidade da parada do equipamento para a realização do reparo;

- programar a parada do equipamento, a fim de minimizar o impacto negativo ao Cliente; 
- reparar o equipamento o mais breve possível e de acordo com o solicitado pela Empresa;

- comunicar a Empresa a realização do trabalho realizado, através do sistema SIMS.

- participar do programa de introdução de novos produtos:

o indicando possíveis Clientes em potencial que poderiam participar e colaborar nos testes de máquinas novas ou atualizadas a serem lançadas;

- acompanhar os "novos" produtos junto ao Cliente, durante a fase de teste e reportar toda falha, sintoma de falha, informação ou comentário do Cliente (operador, gerente, dono) ou do próprio mecânico da Revenda a Empresa, através de e-mail;

- prover imediata intervenção junto ao produto em teste, no caso de falha e comunicar imediatamente a Empresa.

\subsection{Como é realizado o feedback do campo}

Como apresentado anteriormente, o consultor técnico é a pessoa responsável quando o Cliente necessita de informações ou reparos. Ele é o responsável por fazer os primeiros filtros a fim de separar ou categorizar as falhas e para isso necessitará:

- colher informações o mais detalhada e precisa possíveis dos sintomas das falhas; 
- fazer um diagnóstico completo da falha;

- acompanhar o reparo, a fim de poder ganhar mais informações a respeito da remanufatura que está sendo aplicada, a qual pode ser temporária ou definitiva;

- comunicar a Empresa todos os detalhes observados e/ou relatados pelo Cliente e pelo mecânico, através do sistema SIMS:

o número de série da máquina;

- quantidade de horas que ocorreu a falha;

o data da falha;

- nome do Cliente;

- descrição do problema;

○ solução aplicada;

- possível causa raiz da falha;

○ comentário geral.

- solicitar a Empresa ajuda imediata, caso não consiga resolver o problema com a literatura disponibilizada pela Empresa.

O SIMS tem a finalidade de uma rápida comunicação de campo e também manter um histórico, em que periodicamente a Empresa poderá fazer 
pesquisa e priorizar as falhas que deverão ser endereçadas, através de ações corretivas.

\subsection{Dados obtidos através do Programa Parceiro na Qualidade (Partners in Quality - PIQ)}

O objetivo do programa Parceiros na Qualidade é melhorar o nível de comunicação entre fábrica e a Revenda, principalmente para corrigir eventuais falhas ocorridas nas primeiras horas (até 1000 horas) de operação do produto.

Os relatórios PIQ são enviados pelos revendedores via e-mail e/ou fax. São analisados, cadastrados no banco de dados do Programa PIQ e direcionados para as áreas responsáveis (Suporte Técnico ao Produto, Confiabilidade, Compras, Ferramentas \& Soluções, Tráfego ou Pintura, Subsidiárias e Fornecedores), as quais têm um prazo de 3 a 5 dias para responder. As respostas são enviadas ao revendedor e, quando necessário, os relatórios PIQ são mantidos em "follow-up" para futura atualização. Ver fluxo da FIGURA 3.2. 


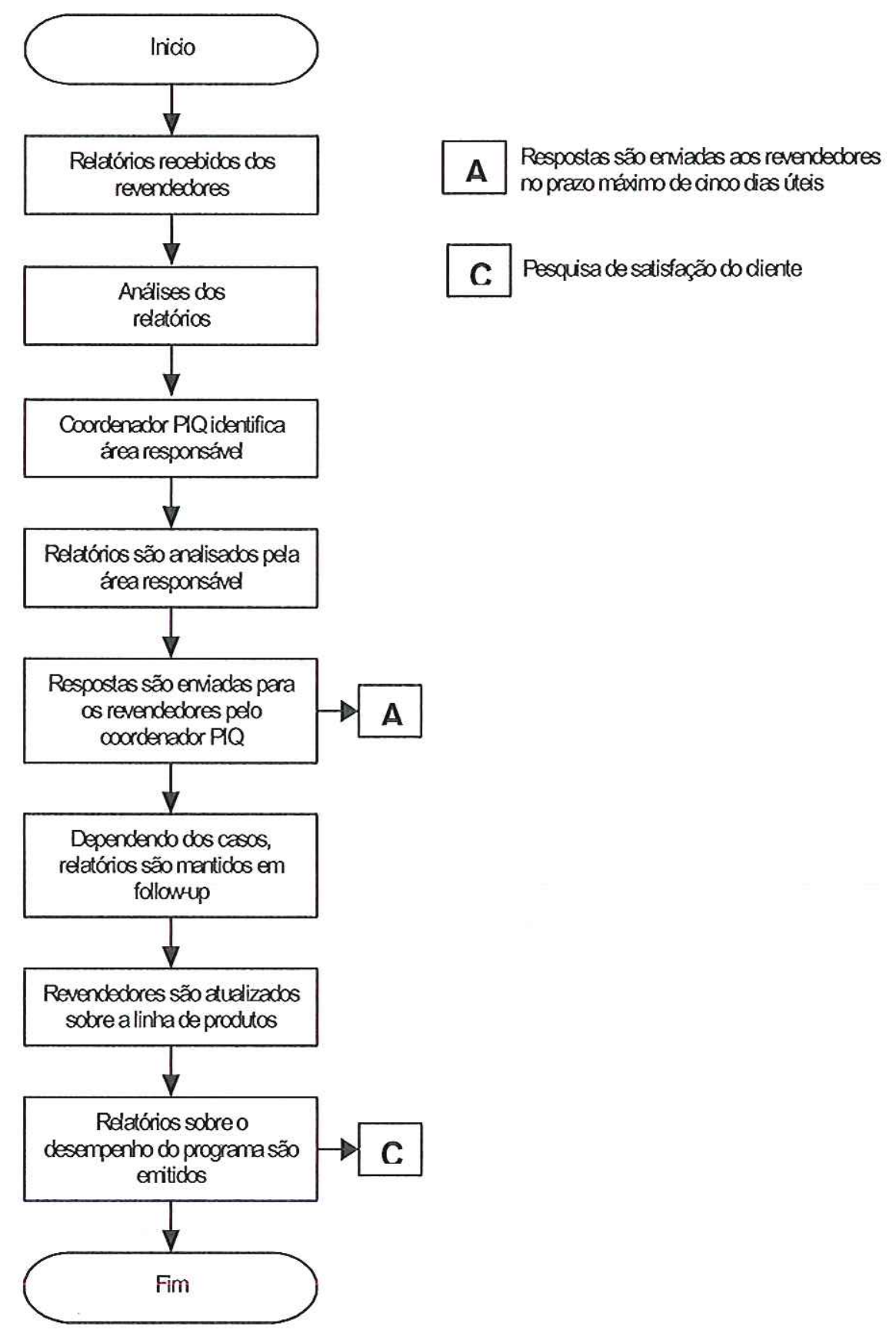

Figura 3-2 - Fluxograma do Programa PIQ 


\subsection{Dados de falhas coletados pela Revenda}

Como já abordado, a Revenda presta todo apoio necessário ao Cliente, visando sempre manter o equipamento do Cliente final em condições de operações. Porém, no que diz respeito à comunicação entre a Revenda e a Empresa, com o intuito de relatar as falhas ou defeitos apresentados pelo produto, existem algumas outras oportunidades de melhoria, visto que algumas vezes as falhas são:

- comunicadas verbalmente e não são registradas no sistema;

- comunicadas através de e-mail, porém não são registrados no sistema SIMS;

- registradas com informações incompletas;

- registradas com informações incorretas;

- são registradas em duplicata.

Prejudicando, desta forma, pesquisas e ações futuras pela Empresa para a prioridade e ações futuras para a correção das falhas ou defeitos.

O sistema utilizado para a comunicação das falhas e defeitos entre a Revenda e a Empresa é o SIMS, tanto para quando o produto está em garantia, como após a vigência da mesma. O procedimento seguinte é seguido após o diagnóstico e ações tomadas pelo mecânico da Revenda:

O comunicador técnico da Revenda é o responsável por coletar todas as informações dos mecânicos, bem como prestar os primeiros auxílios a ele, quando este não tiver a solução imediata para a correção do problema. As seguintes informações são obtidas junto ao mecânico e repassada a Empresa: 
- número de série do produto;

- horas acumuladas até o início da falha;

- nome do Cliente;

- número da peça e grupo do componente falhado;

- descrição da falha;

- descrição da solução adotada;

- custo envolvido para a correção da falha.

Com base nos dados registrados pela Revenda, a Empresa consegue coletar dados a respeito da saúde do produto, através dos indicadores de Confiabilidade:

- falhas ocorridas nas 20 primeiras horas, as quais normalmente são associadas à falha de mão-de-obra;

- falhas ocorridas entre 21 a 200 horas, as quais normalmente são atribuídas ao método de fabricação;

- falhas ocorridas entre 201 a 1000 horas, as quais normalmente são atribuídas ao projeto do produto;

- falhas ocorridas entre 0 a 1000 horas, esse indicador é uma média entre os 3 anteriores e mostra como está a Empresa de uma maneira geral. 


\subsection{A dificuldade de se obter dados sobre os fatores operacionais}

Diversas variáveis afetam a intensidade e o padrão de desgaste e não podem ser controladas, entre elas pode-se incluir:

- taxa de uso;

- forma de operação do produto (adequada, inadequada);

- condições de solo e piso (abrasão, impacto, acumulo de material, etc);

- condições de aplicação (o que a máquina faz);

- condições de terreno (irregularidade do terreno ou da superfície);

- velocidade de percurso;

- carga excessiva.

\subsubsection{Taxa de uso}

A taxa de uso do produto é influenciada pela urgência do término da obra, atendimento ao contrato pré-estabelecido e pela finalidade pela qual foi adquirido o produto. Com isso, tem-se um produto adquirido por um Cliente " $A$ " sendo utilizado apenas algumas horas por mês, enquanto o mesmo produto adquirido pelo Cliente "B" está acumulando 20 horas por dia, 30 dias por mês, 12 meses por ano. 
O deslocamento de máquinas em longas distâncias, com velocidades altas e sem carga é um fator de uso muito difícil de ser observado, pois depende única e exclusivamente do Cliente. Porém esse fator é um acelerador muito grande de desgaste nos produtos, visto que estes produtos não foram projetados para deslocamento de longas distâncias. A FIGURA 3.3 demonstra a distância de transporte par alguns dos sistemas móveis.

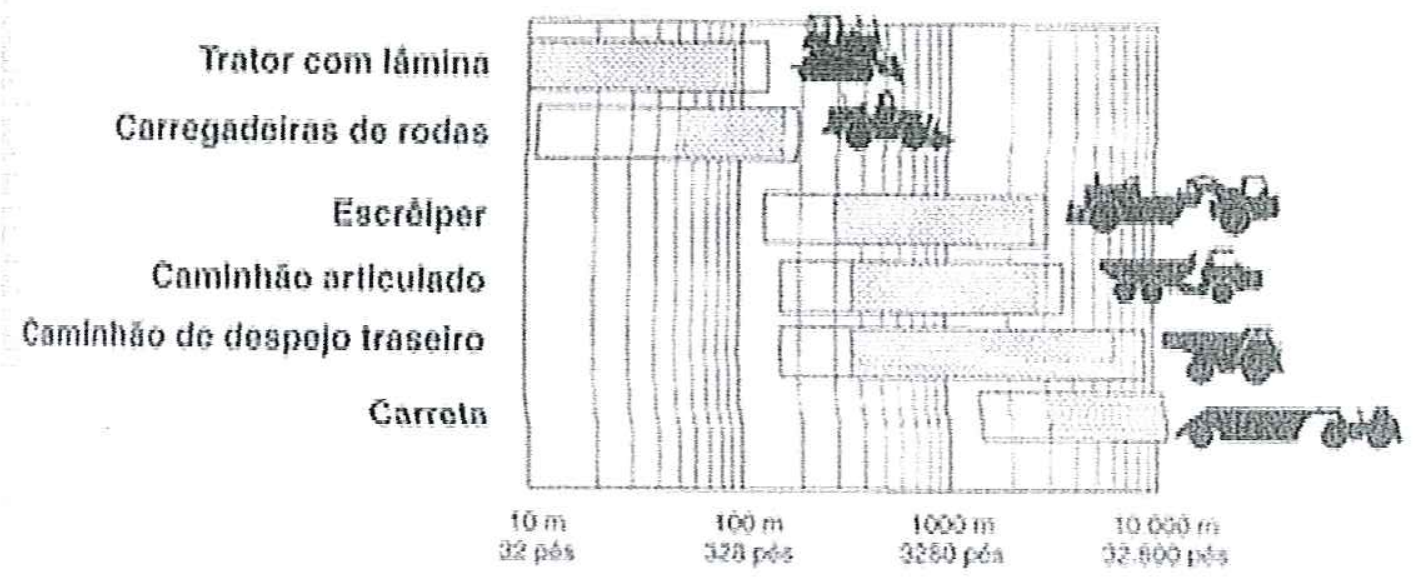

Figura 3.3 Distância de Transporte para Sistemas Móveis

Outro ponto importante a considerar é a altitude da área de trabalho , visto que alguns produtos podem apresentar alguma queda de potência devido à altitude.

A maioria dos fatores, envolvidos na taxa de uso, são muito difíceis de serem coletados pela Revenda e até mesmo pelo Cliente, visto que dependem na maioria dos casos única e exclusivamente dos operadores dos produtos.

\subsubsection{Tipo de aplicação}

O tipo de aplicação influi muito na Confiabilidade do produto, pois na maioria dos materiais a falta de umidade reforça a liga entre as partículas e 
dificulta a remoção do material em seu estado natural. Um alto teor de umidade dificulta a operação de corte porque o material fica pesado e exige mais força para ser deslocado. O teor ideal de umidade reduz a poeira e fornece melhores condições para a operação de corte, além de proporcionar maior conforto ao operador.

O efeito de congelamento depende do conteúdo de umidade. Quando congelada, a liga de material se reforça à medida que o conteúdo de umidade e a temperatura diminuem. Contudo, se o material estiver totalmente seco, o congelamento não alterará suas características.

Para cada família de seus produtos, a Empresa divide a severidade da aplicação em três níveis diferentes: moderadas, médias, rigorosas. Na TABELA 3-1, temos o exemplo das severidades para 3 famílias de produtos:

Tabela 3-1 - Descrição das Aplicações Típicas dos Equipamentos

\begin{tabular}{|c|c|c|c|}
\hline \multirow{2}{*}{$\begin{array}{c}\text { Família de } \\
\text { produto }\end{array}$} & \multicolumn{3}{|c|}{ Descrições das aplicações típicas } \\
\hline & Moderadas & Médias & Rigorosas \\
\hline Trator de esteira & $\begin{array}{l}\text { Reboque de escrêiperes, maioria dos } \\
\text { trabalhos de barra de tração em } \\
\text { agricultura, empilhamento de } \\
\text { materiais e carvāo sem cargas de } \\
\text { impacto. Operação intermitente em } \\
\text { aceleração total }\end{array}$ & $\begin{array}{l}\text { Operações de laminação em argila, } \\
\text { areia e cascalho. Carregamento por } \\
\text { empuxo de escrêiperes, } \\
\text { escarificação em elevações ou } \\
\text { depressões, maioria das aplicaçōes } \\
\text { de desbravamento de terras. } \\
\text { Condições médias de impacto. } \\
\text { Trabalho de produção de aterros. }\end{array}$ & $\begin{array}{l}\text { Escarificação pesada em rocha. } \\
\text { Carregamento por empuxo e } \\
\text { laminação em rocha dura. Trabalhos } \\
\text { em superficies rochosas condiçöes } \\
\text { continuas de alto impacto }\end{array}$ \\
\hline Motoniveladora & $\begin{array}{l}\text { Trabalhos leves de conservação de } \\
\text { estradas. Acabamento. Trabalho } \\
\text { combinado em pátios e estradas. } \\
\text { Trabalhos leves de remoção de } \\
\text { neve. Longos deslocamentos da } \\
\text { máquina }\end{array}$ & $\begin{array}{l}\text { Manutenção de estradas de } \\
\text { transporte. Construção de estradas, } \\
\text { valetamento. Espalhamento de aterro } \\
\text { solto. Preparação e nivelamento de } \\
\text { terrenos. Manutenção rodoviária de } \\
\text { verão, com remoção média a pesada } \\
\text { de neve no inverno. Uso como } \\
\text { niveladora de elevação. }\end{array}$ & $\begin{array}{l}\text { Conservação de estradas com } \\
\text { superficie rigida e com pedras } \\
\text { encravadas. Trabalhos pesados de } \\
\text { espalhamento de aterro. } \\
\text { Escarificação de asfalto ou concreto. } \\
\text { Cargas continuamente pesadas. Alto } \\
\text { impacto. }\end{array}$ \\
\hline Escavadeira & $\begin{array}{l}\text { Trabalhos gerais de construçāo, com } \\
\text { pouca profundidade, em que a } \\
\text { máquina assenta tubos e escava } \\
\text { apenas em turnos de } 3 \text { a } 4 \text { horas. } \\
\text { Material de fácil escoamento e de } \\
\text { baixa densidade, pouco ou nenhum } \\
\text { impacto. Maioria dos arranjos para } \\
\text { manuseio de refugos }\end{array}$ & \begin{tabular}{|l|} 
Escavação em massa ou \\
valetamento onde a máquina escava \\
continuamente em solos compostos \\
por camadas de argila natural. \\
Algumas operaçōes estacionárias e \\
em movimento à aceleração total. \\
Maioria das aplicações de \\
carregamento de toras.
\end{tabular} & $\begin{array}{l}\text { Valetamento continuo ou } \\
\text { carrregamento de caminhões em } \\
\text { solos de rochas ou pedras } \\
\text { fragmentadas. Elevado índice de } \\
\text { deslocamento em terreno dificil. } \\
\text { Máquina trabalhando continuamente } \\
\text { em solo rochoso, com fator elevado e } \\
\text { constante de carga e alto impacto. }\end{array}$ \\
\hline
\end{tabular}




\subsubsection{Mau uso}

A condição de operação refere-se à adequação do ambiente de uso relativo à variável de projeto inicialmente estabelecida (Revista brasileira de gestão e desenvolvimento de produto, 2002). Essa condição necessita ser bem definida, dado que o sucesso de um evento pode não se manter se as premissas estabelecidas forem alteradas. A condição de operação está relacionada com os aspectos técnicos e humanos. Significa dizer que formação e capacitação dos agentes de operação são condições fundamentais para a garantia da Confiabilidade do produto .

Durante a pré-entrega do equipamento, o consultor técnico é a pessoa que deverá dar as informações técnicas e as recomendações a serem seguidas para que o produto tenha um bom desempenho e proporcione a produtividade esperada pelo Cliente.

\subsection{Conclusão}

Considerando que a Empresa em questão visa sempre à melhoria contínua de seus produtos e serviços, será analisado o processo de atendimento a itens não conformes no campo avaliando a comunicação entre a Revenda e a própria Empresa, com base no exposto nos capítulos 2 e 3. Para tanto, serão apresentadas algumas criticas das pesquisas e análises realizadas no processo da Empresa de atendimento a itens não conforme no campo.

A pesquisa de satisfação enviada direto ao Cliente é muito importante para o Cliente e para a Empresa avaliarem a Revenda e a própria Empresa. $\mathrm{Na}$ verdade, este é um dos caminhos diretos de comunicação entre o Cliente e a Empresa. 
Mesmo sendo difícil conseguir obter informações a respeito dos fatores operacionais, uma aproximação entre o Cliente, Revenda e Empresa, através de programas de visita, tanto no ambiente de trabalho do Cliente como na fábrica, juntamente com uma melhor qualificação dos operadores no que diz respeito à manutenção preventiva, bem como cursos de técnicas de operação; podem contribuir muito no diagnóstico e, posteriormente, na solução dos problemas. Como as informações seriam mais claras e precisas por parte do Cliente, o diagnóstico seria melhor efetuado pelo corpo técnico da Revenda e, conseqüentemente, a Empresa teria melhores dados em mãos para poder trabalhar na solução definitiva do problema.

É comum, nos dias de hoje, as Empresas exigirem de seus fornecedores e revendedores a certificação das normas ISO, seja ela 9000 ou 14000 . O intuito é garantir que o nível de qualidade, bem como a sistematização (controle, armazenamento de dados, rastreamento, etc), seja uniforme e consistente em toda a cadeia produtiva de fabricação, bem como nos serviços. No caso da Empresa em questão, ela está trabalhando junto aos seus parceiros (fornecedores e revendedores) na disseminação e implementação da metodologia 6Sigmas, para melhorar o diagnóstico e poder ter uma forma coerente e única para classificação das falhas. Esse é um dos assuntos que será abordado no capitulo 4 . 


\section{CAPITULO IV}

4

Modelo proposto

4.1 Introdução

Neste capitulo será apresentado o método base, recentemente implantado pela Empresa, bem como será proposta uma melhoria no mesmo. Este método é utilizado pela Empresa para coletar, analisar e priorizar informações sobre as falhas ocorridas no campo. Estas falhas são reportadas previamente pela Revenda a Empresa, através de procedimentos formais.

O método base desenvolvido foi baseado na metodologia 6 sigmas e incorporou a metodologia $8 \mathrm{D}$ desenvolvida pela Ford, e tem por finalidade focar, disciplinar e agilizar a solução das falhas vivenciadas pelo Cliente final. A metodologia 6 Sigmas é uma medida de variabilidade, a qual indica o quanto os dados caem dentro dos requisitos do Cliente. Quanto maior o sigma do processo, menor serão os defeitos que o Cliente ira vivenciar. Em outras palavras, 99,99966 \% dos produtos ou serviços atendem os requisitos dos Clientes, com apenas 3,4 falhas por milhão.

O programa 6 Sigma é a implementação rigorosa, concentrada e altamente eficaz de princípios e técnicas comprovadas de qualidade. Sigma é uma letra do alfabeto grego utilizada pelos estatísticos para mensurar a variância em qualquer processo. $O$ desempenho de uma Empresa é medido pelo nível de seus processos Empresariais. Tradicionalmente, as Empresas aceitavam níveis de desempenho de 3 Sigma ou 4 Sigma como normas , 
apesar de saberem que esses processos criam entre 6,2 mil e 67 mil problemas por milhão de oportunidades. O padrão 6 Sigma, com 3,4 problemas por milhão de oportunidades, é uma resposta ao aumento do nível de expectativa dos Clientes e a crescente complexidade dos produtos e processos modernos (Pyzdek, 2003).

6 Sigma foi desenvolvido pela Motorola no final dos anos 80 , como uma maneira de prover um foco claro na melhoria e ajudar a acelerar o grau de mudança em um ambiente competitivo acirrado. O conceito, ferramentas e sistema de 6 Sigma têm evoluído e expandido através dos anos, mais recentemente através dos exemplos da GE e AlliedSinal/Honeywell, e isso têm ajudado continuamente reacender o interesse e redobrar os esforços na melhoria do processo e qualidade (Pande, Neuman \& Cavanagh, 2000)

A TABELA 4.1 abaixo mostra a relação simplificada entre o percentual de confiança, defeito por milhão e o Sigma, com isso temos uma noção claro de quão difícil é colocar em pratica um processo 6 Sigma:

Tabela 4-1 - Conversão simplificada do sigma (Pande, Neuman \& Cavanagh, 2000):

\begin{tabular}{|c|c|c|}
\hline Percentagem (\%) & Defeitos por milhão & Sigma \\
\hline 30.9 & 690 & 1.0 \\
\hline 69.2 & 308 & 2.0 \\
\hline 93.3 & 66.8 & 3.0 \\
\hline 99.4 & 6.21 & 4.0 \\
\hline 99.98 & 320 & 5.0 \\
\hline 999.997 & 3.4 & 6.0 \\
\hline
\end{tabular}




\subsubsection{Metodologia 8D}

A metodologia 8D, desenvolvida pela Ford, tem como objetivo padronizar a solução de problema. Para isso busca entender um problema através da disciplina dos 8 passos:

- D0 - prover uma Ação de Reparo Emergencial:

- Tomar uma ação para isolar e proteger o Cliente de um sintoma antes que solução permanente seja implementada.

- D1 - estabelecer uma equipe:

- estabelecer uma equipe com pessoas com conhecimento do processo ou produto e conhecimento técnico necessário para resolver o problema.

- D2 - descrever o problema:

o descrever em detalhe o problema em termos quantitativos. Esses dados devem ser endereçados se a falha tiver que ser resolvida.

- D3 - desenvolver uma Ação de Correção Temporária:

- tomar uma ação que proteja o Cliente de efeitos da falha, na perspectiva de tempo, qualidade ou custo.

- D4 - definir a causa raiz: 
- o objetivo é isolar e verificar a causa do problema e o ponto de fuga do processo.

- D5 - escolher uma Ação de Correção Permanente:

- selecionar a melhor ação de correção permanente que enderece a causa raiz e a fuga do processo identificada na fase anterior.

- D6 - implementar a ação de correção permanente:

- planejar e implementar a ação de correção permanente escolhida.

- D7 - previnir re-ocorrência:

- o objetivo desta fase é modificar o que for necessário no sistema para prevenir re-ocorrência de problemas similares, fazer recomendações para mudança fora do escopo do trabalho que esta sendo endereçado pela equipe $e$ documentar toda e qualquer lição aprendida para servir de base para melhoria contínua.

- D8 - revisão gerencial:

- assegurar que a equipe que trabalha na resolução do problema esteja satisfeita com a solução implementada e prover uma oportunidade para reconhecer 0 resultado alcançado pela equipe. 


\subsubsection{Justificativa da escolha técnica de diagnóstico}

O modelo a ser descrito é baseado na metodologia 6 sigmas, a qual é altamente técnica. É utilizado para diagnosticar oportunidades de melhorias de produtos e processos. O modelo cria novos processos, produtos, serviços dentro da qualidade 6 Sigma e pode ser descrito da seguinte maneira:

- processo de melhoria (DMAMC - Definir / Medir / Analisar / Melhorar / Controlar):

- melhora processos, produtos, serviços e fábricas existentes através da qualidade 6 Sigma.

- processo de criação (DMEDI - Definir / Medir / Explorar / Desenvolver / Implementar):

- cria novos processos, produtos, serviços e fábricas dentro da qualidade 6 Sigma.

- gerenciamento de processo:

- permite sustentar e nivelar os ganhos adquiridos pelos processos DMAMC e DMEDI.

Aplicando a metodologia 6 sigma no processo de resolução de problemas de campo, analisando o que estava funcionando e o que não estava funcionando no processo atual, algumas melhorias foram identificadas, como segue (Caterpillar, 2003):

- reconhecer os problemas de produto mais cedo - todas as questões de produto são registradas e investigadas e todos os revendedores têm acesso a relatórios de status para acompanhar o progresso; 
- priorizar os problemas de produto para ter certeza que os mais importantes estão sendo endereçados - todos os problemas são avaliados com o mesmo critério;

- ter um processo comum - todos usam o mesmo banco de dados e compartilham a mesma informação;

- ter uma pessoa responsável pelo processo e alocar recurso para isso - uma equipe de trabalho liderado por um Faixa Preta conduz todas as atividades para a solução do problema.

\subsubsection{DSN - Dealer Solution Network}

A rede de soluções para a Revenda (DSN) é um sistema utilizado pela Empresa como um canal direto e rápido de comunicação entre a Revenda e a Empresa. Consiste em pessoas que coletam eventos (falhas / reclamações / solicitações de informações) ocorridos ou vivenciados pelo Cliente ou pela própria Revenda, os quais são registrados em sistemas informatizados.

O DSN está estruturado de tal forma que qualquer revendedor do mundo pode entrar em contato com a central de atendimento via telefone, a qualquer hora do dia, em qualquer dia da semana, que sempre haverá uma pessoa disponível para atendê-lo e ajudá-lo, seja respondendo à solicitação ou encaminhando-a aos especialistas no assunto. Isso é possível, porque os vários centros de atendimento aos revendedores estão estrategicamente distribuídos no mundo e interligados entre si, de tal forma que um ou mais centros estão operando a qualquer hora que o revendedor necessite. 
Considerando que os centros estão interligados entre si, quando o revendedor liga para um deles, e o mesmo está fechado, a ligação é automaticamente transferida para o centro que está aberto.

Para registrar os eventos relatados pela Revenda, um sistema "on line" está disponível, em que os dados são relatados pela Revenda e registrado pelo analista.

Os analistas avaliam e provêem todas as informações necessárias para responder aos questionamentos da Revenda. Caso não tenham as informações necessárias para solucionar ou auxiliar a Revenda, o evento é direcionado pelo analista aos especialistas dos produtos, na fábrica. Estes, por sua vez, passam a ser os responsáveis por dar uma solução / orientação ao revendedor, sobre como ele deverá proceder para a solução do problema. Essas informações são documentadas no sistema pelos próprios especialistas do produto, servindo de histórico e referência para futuras ocorrências. A FIGURA 4.1 mostra como é fluxo de informação entre o revendedor (comunicador técnico) e a Empresa (DSN - analista e Especialista de produtos).

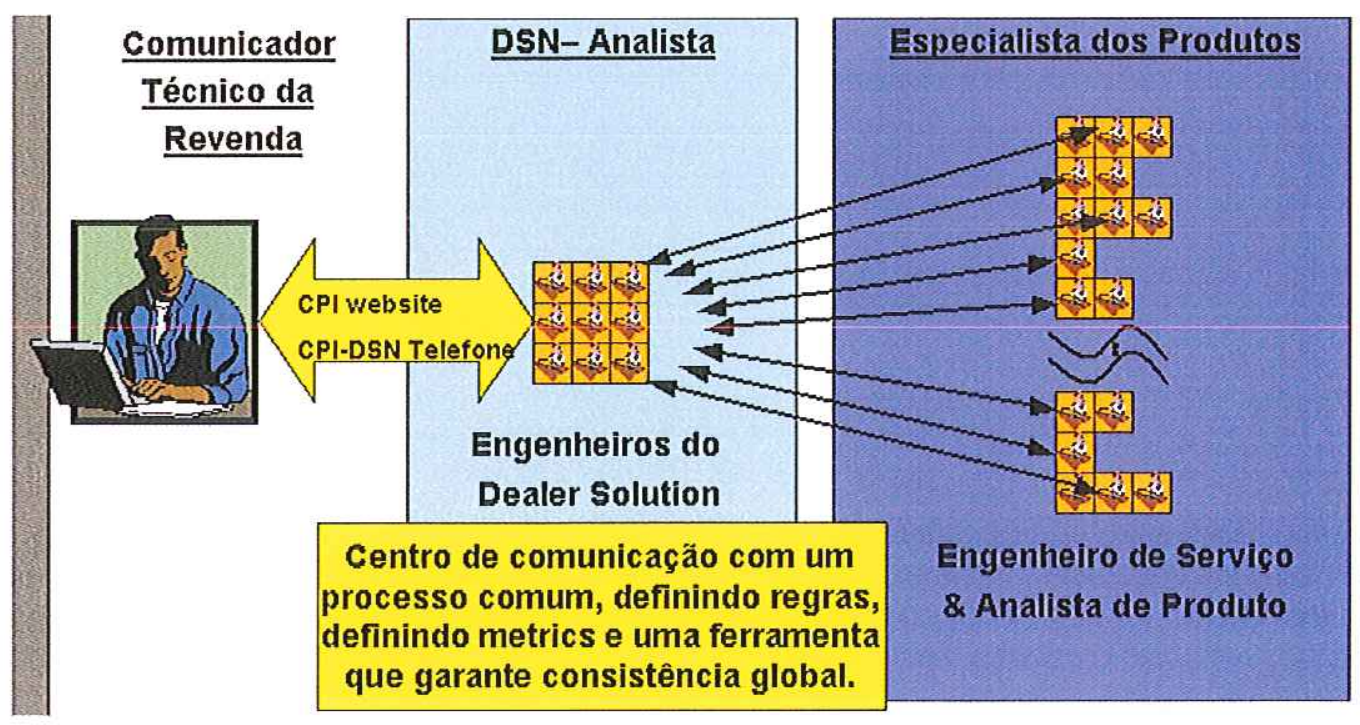

Figura 4-1 - Fluxo de informação do DSN 
O analista que abre a solicitação ou chamado é o dono desta solicitação, com isso ele é o responsável para que a mesma seja fechada dentro do tempo pré-estabelecido. Mesmo as solicitações direcionadas aos especialistas de produtos devem ser monitoradas pelos analistas.

Cada vez que um evento é registrado, modificado, respondido ou direcionado para alguém; uma mensagem eletrônica é automaticamente gerada e enviada ao solicitante, ao atendente e ao especialista.

Os eventos são chamados de eventos CPI e são os primeiros indicadores de potenciais falhas no produto. Eles podem ser classificados das seguintes maneiras:

- problema de produto:

- máquina parada - 24 horas para ser respondida;

- problema de produto - 48 horas para ser respondida.

- informação - 72 horas para ser respondida.

Mesmo após a falha ter sido solucionada, o registro contínua no histórico do banco de dados, para referência futura. Além do que, a cada 3 falhas ocorridas na mesma peça, é o bastante para que uma análise mais profunda seja feita, a fim de determinar a necessidade ou não da instauração de um projeto 6 Sigma, para melhoria contínua do produto. 


\subsection{Método base}

Com base nos registros dos sistemas utilizados pela Revenda, para solicitar garantia, e no sistema utilizado pelo DSN, o processo CPI é iniciado a cada vez que um determinado componente apresentou 3 ou mais falhas, independente, se o equipamento do Cliente está em operação ou não.

Este método visa atender a voz do cliente, que necessita rapidez no reconhecimento e solução dos problemas; e a voz do negócio onde a Empresa visa reduzir custos com garantias e manter maior margem possivel sobre os seus produtos. A falha é quantificada e priorizada considerando sete requisitos críticos, os quais estão listados abaixo e apresentam diferentes pesos variando individualmente entre 0 a 10. Após serem aplicados em um modelo matemático de propriedade e uso exclusivo da Empresa, a pontuação final do problema pode variar entre 0 a 5000 pontos.

- Segurança/Risco danos pessoais

- Desempenho conforme anunciado

- Custo com garantia envolvida no reparo

- Idade do problema

- Incidência do problema

- Recorrência do problema

- Tempo de reparo do problema

A partir do momento que a falha está priorizada, a que possuir a maior pontuação passa a ter a prioridade, foco e recursos necessários para sua 
solução. Sendo assim, ele é transferido para a fábrica causadora da mesma, a qual transforma o evento em projeto de melhoria contínua de produto em que um Faixa Preta passa a conduzir todas as atividades, seguindo a metodologia 6 Sigma e atendendo o tempo pré-estabelecido para a solução do mesmo. 0 tempo de resolução do problema é estabelecido, levando em consideração a complexidade para a solução do problema.

\subsubsection{Quando uma solicitação pode ser encerrada}

Uma solicitação pode ser considerada resolvida quando:

- uma informação solicitada foi respondida:

- a informação técnica solicitada tenha sido documentada no sistema "on line" e comunicada via correio eletrônico / telefone ao solicitante.

- um evento CPI tenha sido respondido, quando:

- o melhor procedimento de remanufatura conhecido tenha sido documentado e comunicado ao revendedor;

- qualquer outra ação necessária tenha sido tomada como um resultado, provendo informação ao solicitante.

Considerando todo o exposto até o momento, pode-se sumarizar o ciclo de resolução da falha apresentada no produto, quando o mesmo estiver nas mãos do Cliente final, conforme a FIGURA 4.2. 


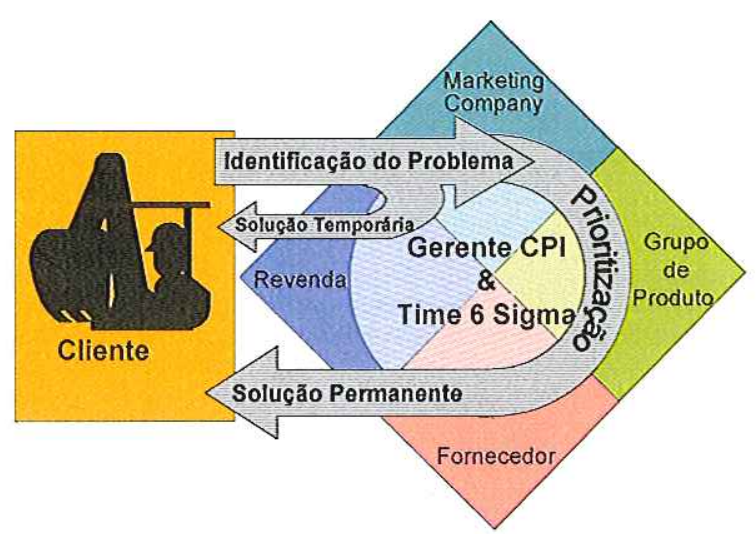

Figura 4.2 - Ciclo de resolução

\subsection{Modelo proposto}

Como dito anteriormente, a melhoria do modelo base se baseará na metodologia 6 Sigma, na metodologia 8D aplicada pela Ford e na experiência acumulada pelos especialistas de produto e dos procedimentos utilizados pela Empresa, no tratamento das falhas de campo. A FIGURA 4-3 expressa essa idéia.

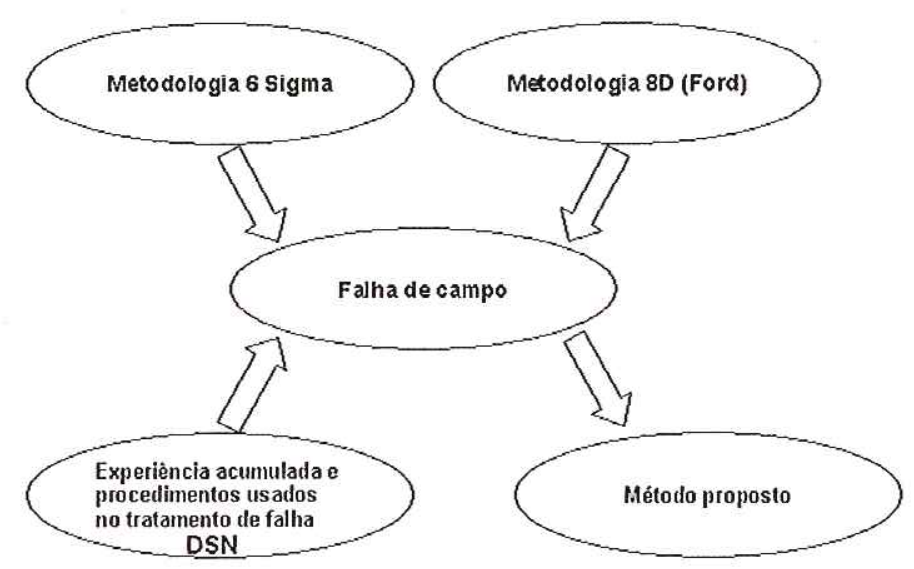

Figura 4-3 - Surgimento do modelo proposto 


\subsubsection{Detalhe do modelo base}

Antes de propor uma melhoria no modelo utilizado pela Empresa, vale a pena conhecer com mais detalhes os oito passos do modelo atual em uso, o qual abrange desde a fase de coleta de dados até a solução permanente e identificação do processo que está gerando o problema.

D1 - Capturar eventos e suportar as solicitações da Revenda

Os objetivos principais desta fase são:

- capturar eventos de problema de produto para ser usado na metodologia CPI para identificar, priorizar e resolver problemas;

- para comunicar instruções validadas de recuperação para auxiliar o processo de remanufatura da Revenda.

Os eventos capturados incluem problema de produto, como falha de peças, desempenho do produto abaixo do especificado e itens de segurança. Dois sistemas são utilizados como as bases da pesquisa:

- banco de dados do sistema de registro de falhas e garantia:

- o processo e as ferramentas deste sistema são desenhados para capturar a maioria dos reparos e todas as solicitações de garantia aplicadas no produto.

- solicitações registradas pelo DSN.

- O processo, as ferramentas e os recursos deste sistema capturam os eventos atuais, ou seja, os eventos que estão 
ocorrendo no momento e também auxiliam a Revenda num reparo, quando necessário.

D2 - Criar e investigar projetos em potencial

O objetivo desta fase é identificar projetos de melhoria contínua do produto para ser trabalhado o mais rápido possível e minimizar o número de "falso" problema a ser trabalhado, utilizando a metodologia 6 Sigma.

Como exemplos de falso problema a ser trabalhado, pode-se citar:

- aplicação inadequada ou abusiva do produto;

- prática de manutenção inadequada;

- incorreta expectativa de desempenho do produto;

- desgaste normal de peças ou equipamento.

Todos os potenciais problemas de produto sendo investigados são documentados como projetos em potencial e são gerenciados por uma lista, em que são priorizados. Porém, nessa fase, não é esperado que as fases Definir e Medir do DMAIC sejam completados totalmente.

Também são incorporados pelo processo de melhoria contínua do produto, eventos identificados em outro tipo de processo, como:

- introdução de novos produtos;

- fábrica; 
- fornecedor;

- relatório de visita a Cliente.

Relatórios periódicos de todos os bancos de dados devem ser gerados para servir de base para as investigações e a criação dos projetos em potencial. A periodicidade depende de cada sistema.

Os campos requeridos na abertura de um projeto em potencial são:

- título do problema;

- descrição do problema;

- razão da abertura deste documento;

- nível de segurança;

- data da abertura;

- data em que o problema foi reconhecido como tal;

- complexidade;

- pontuação do evento;

- modelo e número de série;

- número da peça e grupo. 
Antes de dar seqüência ao processo, é fundamental saber se as informações coletadas durante a fase de investigação são suficientes para determinar se o item analisado se caracteriza como problema de produto. Para isso, as seguintes perguntas necessitam ser respondidas:

- Qual é o problema a ser endereçado como projeto de melhoria contínua do produto?

- Quais são as razões financeiras que fazem este item ser um projeto de melhoria contínua do produto?

- Qual é a performance atual?

- Podem ser calculados a pontuação e o resultado financeiro como linha base deste projeto de melhoria contínua do produto?

- Quais são os limites ou escopo do projeto de melhoria contínua do produto?

- Qual é o objetivo do projeto de melhoria contínua do produto?

Se as perguntas não podem ser respondidas adequadamente, a fase de investigação do problema em potencial deve continuar coletando informações. Se, após a fase de investigação, o problema em potencial não for transformado em projeto, todos os dados, benefícios e pontuações levantados, bem como o por que ele não foi transformado em projeto, neste momento, devem ser documentados no sistema.

D3 - Criar e atualizar projeto

Essa fase tem dois objetivos principais: 
- transformar o problema em potencial já investigado em projeto e direcioná-lo ao correto responsável, e, como a Empresa em questão é uma Empresa multinacional, isso significa que o projeto será endereçado à fábrica causadora do problema;

- recomendar e documentar a ação de reparo temporário. Isso inclui ações de contenções na fábrica e seus fornecedores e qualquer ação que o revendedor puder tomar para manter o Cliente com o equipamento em operação.

A definição e implementação da ação de reparo temporário é uma ação muito importante no processo de solução de problemas, visto que a Empresa está reconhecendo o problema e está cuidando do Cliente. Mesmo não sendo uma solução definitiva, o objetivo é minimizar o impacto que o problema está causando ao Cliente. Para atender estes requisitos é necessário:

- a descrição da ação de reparo, como por exemplo: substituir a peça falhada por uma nova do mesmo número;

- a literatura que está suportando esta ação;

- os números de séries que estão sendo afetados por esta ação.

Nesta fase, uma proposta de projeto 6 sigma deve ser preenchida para este problema que está sendo transformado em projeto de melhoria contínua do produto.

D4 - Implementar uma correção temporária

O objetivo desta fase é prover uma ação de reparo temporária para o projeto de melhoria contínua do produto recém-criado, o mais breve possível, 
como medida de contenção para o problema que o Cliente ou revendedor está enfrentando.

Alguns passos requeridos por esta fase são:

- ação de contenção junto ao fornecedor e a cadeia de distribuição;

- remanufaturar peças em estoque;

- capturar e documentar a ação de reparo temporário realizado pela Revenda;

- desenvolver uma ação de validação do reparo temporário;

- estabelecer uma publicação para comunicar a ação de reparo temporário à rede de revendedores.

Após a implementação da ação de reparo temporário, um acompanhamento se faz necessário, a fim de conhecer a eficácia da solução sugerida. Toda informação proveniente desta ação deve ser registrada no sistema on line sob o número do projeto $\mathrm{CPI}$, como histórico e também para auxiliar no andamento da solução definitiva do projeto.

\section{D5 - Definição da causa raiz}

Com o intuito de solução definitiva do problema, esta fase é fundamental para o direcionamento correto das ações da equipe de trabalho. Os objetivos principais desta fase são:

- identificar claramente as causas raiz do problema; 
- prover evidências conclusivas de como cada causa raiz contribui na formação do problema.

Uma identificação de causa raiz incorreta pode ter conseqüência irreparável, visto que conduzirá a equipe a uma tomada de decisão incorreta, o que não solucionará o problema junto ao Cliente, e a credibilidade da Empresa, e principalmente da equipe de trabalho, ficará muito comprometida.

Uma das principais ferramentas utilizadas na identificação das causas raízes é o Diagrama de Ishikawa ou de causa e efeito, FIGURA 4-4, o qual:

- é, basicamente, uma ferramenta para organizar informações que estabelecem e esclarecem as relações entre um efeito e suas principais causas;

- identifica a causa raiz do problema para que ações coletivas possam ser tomadas para eliminar sua recorrência;

- apresenta uma ilustração composta por palavras e linhas destinadas a mostrar a relação entre o efeito e suas causas.

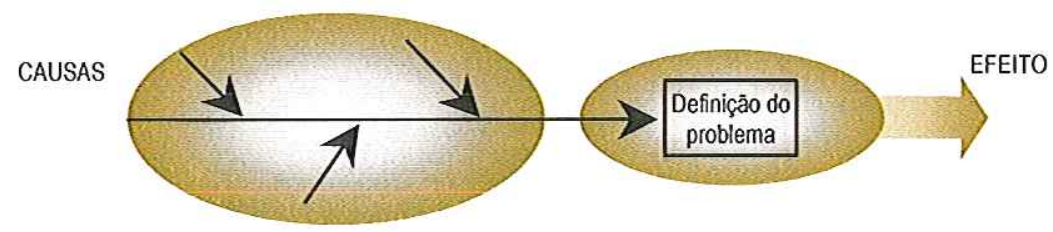

Figura 4-4 - Diagrama de causa e efeito (6 Sigma 2003)

Outra ferramenta é a causa raiz em potencial, mais conhecida como diagrama por que, por que, FIGURA 4-5, ou seja: 
- Por que isto ocorre?

- Por que existe esta condição?

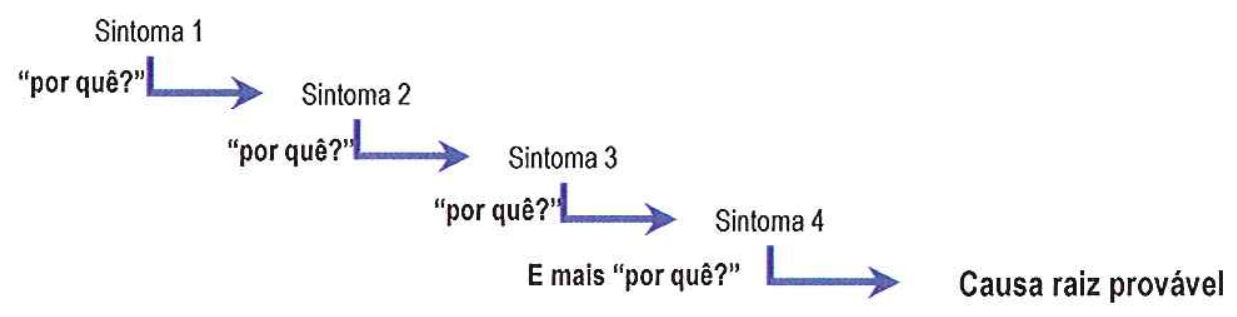

Figura 4-5 - Diagrama Por que? Por que? (6 Sigma 2003)

D6 - Desenvolver e validar soluções

O objetivo desta fase, como o próprio nome diz, é desenvolver uma solução definitiva para o problema endereçado por este projeto e validá-lo antes de introduzi-lo ou comunicá-lo ao Cliente ou à Revenda. Esta fase compreende os seguintes passos:

- concordar com o critério a ser usado para selecionar a melhor solução;

- desenvolver soluções alternativas para endereçar a causa raiz do problema;

- selecionar a melhor delas e colocar em produção e no campo para resolver os produtos a serem produzidos, bem como os já produzidos;

- validar, provar que a solução escolhida funciona. 
D7 - Implementar solução permanente

Uma vez desenvolvida a solução, resta agora implementá-la. Para isso, alguns passos são necessários:

- gerenciar a transição da peça velha para a nova, de uma forma coerente e eficaz:

- programação para a produção e peça de reposição deve ser feita em paralelo, com constante monitoramento.

- plano para suportar o campo deve ser atualizado e implementado:

o as condições e os termos devem ser definidos;

- o procedimento de reparo deve ser documentado e comunicado ao campo.

- número de série do produto que recebeu a melhoria deve ser registrado no sistema on line.

Um projeto CPI somente poderá ser considerado fechado pela Empresa se atender às seguintes condições:

- todos os requisitos do projeto 6 Sigma DMAIC foram atendidos;

- todos os requisitos do $\mathrm{CPI}$ forma atendidos:

- 3P: 
" peças: as peças disponiveis para suportar a necessidade do campo em base mundial, de acordo com o procedimento de reparo publicado;

" produção: as peças com as melhorias estabelecidas estão disponíveis na linha de montagem e os números de series das máquinas que passaram a utilizá-las estão registrados;

- publicação: estar disponível para o revendedor descrevendo a melhoria do produto implementada pela Empresa e o número de série do produto que começou a receber tal melhoria.

o o sistema on line foi atualizado:

" se os dados não estiverem atualizados, passo a passo, o projeto CPI não pode ser fechado.

D8 - Identificar o processo que produz defeito

O objetivo nesta fase é identificar e resolver defeitos no processo acima que gera problemas de produto $\mathrm{CPI}$, a fim de evitar:

- futuras ocorrências do mesmo problema;

- similar ocorrência em produtos similares.

Todo projeto deve passar por esta fase a fim de avaliar se outras peças com processos similares podem aproveitar o trabalho desenvolvido e implementado, utilizando a mesma solução aplicada na resolução de um determinado problema. Com isso se estará atuando preventivamente e 
tornando o processo mais robusto, além de minimizar custo de garantia e descontentamento do Cliente.

Caso um processo deficitário seja identificado, um projeto 6 Sigma deve ser escrito juntamente com os dados e fatos do projeto CPI, e o dono do processo deve ser comunicado a fim de que fique ciente da necessidade de melhoria do processo e do risco que este está causando às peças por ele sendo fabricadas.

O fluxograma da FIGURA 4-6 mostra como os oito passos do modelo de melhoria contínua do produto é incorporado na metodologia 6 Sigma:

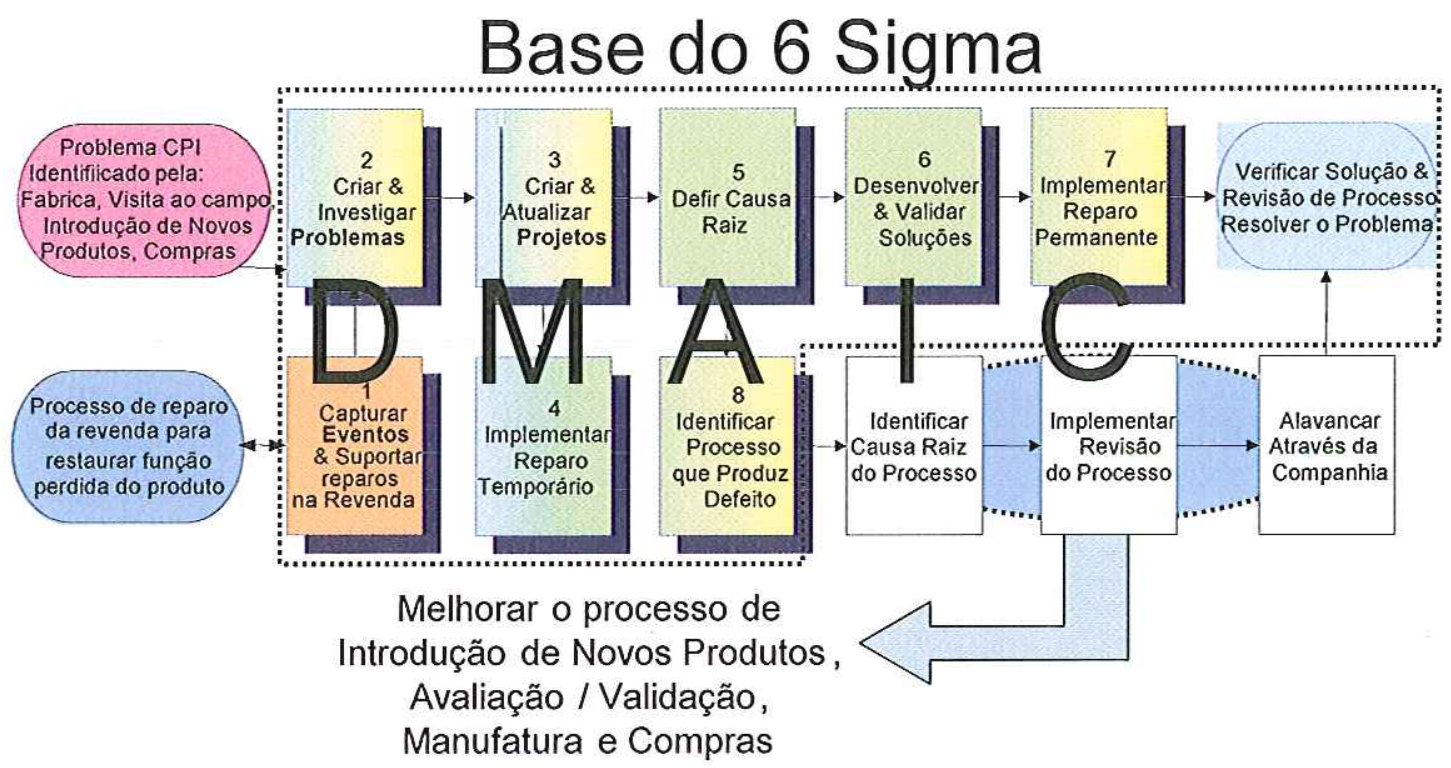

Figura 4-6 Base 6 Sigma

Este método desenvolvido pela Empresa, incorporando a metodologia 6 Sigma na solução de problemas de campo, reduziu significativamente o tempo de resolução do mesmo. Apesar da nova metodologia, a Empresa também teve que atuar na mudança cultural das pessoas, pois, como foi visto anteriormente, deixou-se de focar a reclamação verbal, as pressões por solução de um 
determinado problema, por atacar os problemas priorizados por pontuação, com regras predefinidas e claras.

\subsection{Proposta de melhoria no método}

Apesar do grande avanço no prazo e forma de resolução de problemas enfrentados pelo Cliente, e considerando que a Empresa em questão está sempre buscando a melhoria contínua de suas atividades e produtos, após algum tempo utilizando este novo método, foi possível verificar algumas oportunidades de melhoria do mesmo, como antecipação da ação de contenção e atuação nos problemas de menor pontuação, porém que impacta negativamente o Cliente e a Empresa. Estas duas propostas estão descritas abaixo:

1) Fase D2 - Criar e investigar projetos em potencial

a. a melhoria proposta nesta fase visa implementar uma ação de contenção imediatamente após a detecção do problema em potencial, o que trará um efeito benéfico, visto que a Empresa deixará de enviar produtos com problemas em potencial aos seus Clientes, tão logo o problema seja reconhecido como tal.

2) Fase D3 - Criar e atualizar projeto:

a. a melhoria recomendada nesta fase é com relação a projetos com pontuações muito baixas, seja devido ao valor de garantia ser muito pequeno ou devido à incidência de falha registrada até o momento não o colocar no topo da lista de prioridade. Nestes casos, a sugestão seria tratá-los dentro das equipes de multifuncionais, porém seguindo uma metodologia mais 
simplificada e, conseqüentemente, mais rápida. Porém todos os dados investigados, trabalhados ficam registrados em procedimentos formais da Empresa.

Em cada Equipe de multifuncional têm-se representantes de várias áreas como:

- Engenharia do produto;

- Produção;

- Confiabilidade do produto;

- Planejamento de produção;

- Compras;

- Suporte ao produto.

É importante que toda e qualquer ação de investigação e análise, bem como toda ação colocada em prática para solucionar um determinado problema, não seja documentada num sistema local e sim em sistema compartilhado, em ambientes em que toda a companhia possa consultar e visualizar.

b. outra melhoria proposta nesta fase é a implementação de um relatório a respeito da operação desempenhada pelo produto, a fim de eliminar a possibilidade de interpretação incorreta a respeito do problema a ser trabalhado. Isso evitará que durante o desenrolar das atividades os membros da equipe de trabalho fiquem questionando se o problema estaria ou não relacionado com a aplicação. 
Todas as melhorias acima sugeridas são exeqüíveis e têm como objetivo principal: agilizar o processo de análise e solução de problemas, e elas são frutos da utilização pratica do processo de melhoria continua.

\subsubsection{Exemplo do modelo}

No exemplo a seguir, FIGURA 4.7, tem-se um resumo da metodologia de solução de problema atualmente em uso pela Empresa, a qual foi descrita no item 4.3.1 Detalhe do modelo base. É desta maneira que são armazenado e registrados todos os dados e passos utilizados para analise e solução de um determinado problema. Também pode-se fazer 0 acompanhamento do progresso da solução dos problemas através dos status do 8 passos da metodologia.

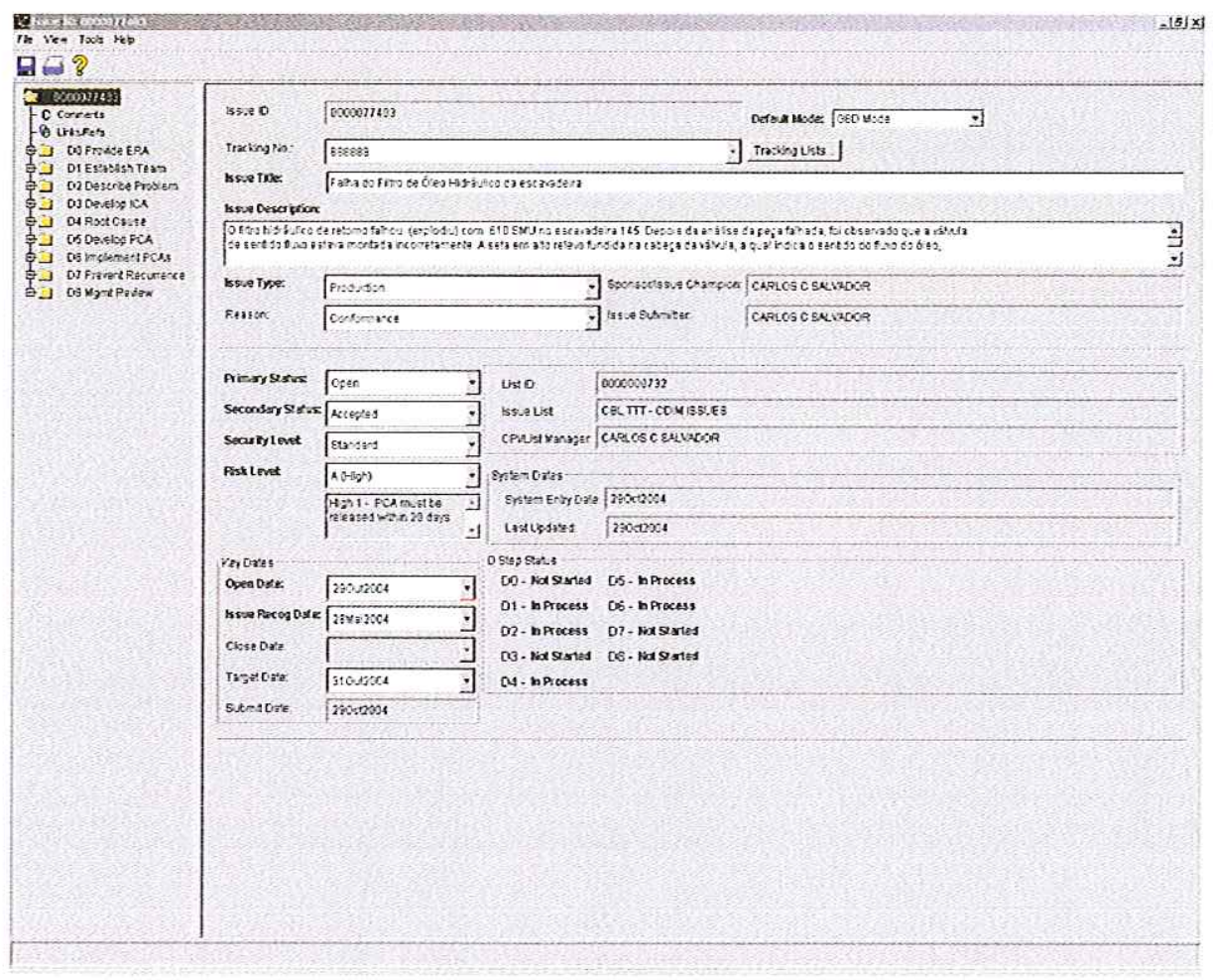

Figura 4-7 - Metodologia 8D 
Na metodologia atual em uso pela Empresa, tão logo um problema seja reconhecido ele é pontuado e classificado, porém isso não significa que necessariamente ele será endereçado de imediato, conseqüentemente uma ação de contenção será implementada junto a Empresa a partir do momento que a equipe iniciar suas atividades, o que poderá ocorrer depois de um certo tempo, dependendo da posição na classificação, que o mesmo obtiver.

A proposta deste trabalho é adotar uma ação de contenção tão logo o problema seja reconhecido como tal, independente da posição da classificação obtida pelo problema. Isso não significa que a ação de contenção seja a solução definitiva do problema, uma nova e melhor ação poderá ser adotada pela equipe a partir do momento que o problema seja mais profundamente estudado, porém a ação de contenção será uma ação que evitará que o problema conhecido continue sendo enviado ao Cliente final.

Abaixo estaremos mostrando comparativamente através da TABELA 4.2, a melhoria proposta na Fase D2 - Criar e investigar projetos em potencial versus a seqüência normal seguida na metodologia em uso pela Empresa. Com este exemplo pode-se quantificar o ganho obtido utilizando a melhoria proposta neste trabalho, ou seja, uma vez reconhecido o problema foi implementado de imediato uma contenção junto à fábrica, o que possibilitou que 55 produtos não fossem enviados ao Cliente final, com um problema conhecido. 
Tabela 4-2 - Comparação entre o método atual e o proposto

\begin{tabular}{|l|c|c|}
\hline \multicolumn{3}{|c|}{ Comparação entre o Método atual e a melhoria proposta } \\
\hline & Método atual & Melhoria \\
\hline Data do conhecimento do problema & $10 / \mathrm{nov} / 03$ & $10 / \mathrm{nov} / 03$ \\
\hline Data da abertura do documento & $10 / \mathrm{nov} / 03$ & $10 / \mathrm{nov} / 03$ \\
\hline $\begin{array}{l}\text { Data do inicio do Projeto } \\
\text { Data da contenção }\end{array}$ & $4 / \mathrm{fev} / 04$ & $4 / \mathrm{fev} / 04$ \\
\hline $\begin{array}{l}\text { Número de série da 1a. máquina após a } \\
\text { contenção }\end{array}$ & 351 & $10 / \mathrm{nov} / 03$ \\
\hline $\begin{array}{l}\text { Valor da remanufatura por máquina } \\
\text { Diferença entre o método atual e a } \\
\text { melhoria proposta }\end{array}$ & $\mathrm{R} \$ 473,00$ & $\mathrm{R} \$ 473,00$ \\
\hline $\begin{array}{l}\text { Valor da remanufatura evitado entre o } \\
\text { método atual e a melhoria proposta }\end{array}$ & 55 máquinas \\
\hline
\end{tabular}

A outra melhoria proposta refere-se aos problemas de baixa pontuação, o que significa que não serão trabalhados no momento e nem num futuro próximo, a não ser que a pontuação aumente e conseqüentemente se aproxime do topo da lista de prioridade. O exemplo abaixo mostra como a equipe de CPPD poderá registrar as investigações realizadas, bem como as ações tomadas para a resolução de problemas. Como pode ser visto na FIGURA 4.8, a grande diferença entre a forma expressa e a metodologia $8 D$, é que a expressa possui somente 4 fases Dados Principais, Detalhes, Causa Raiz e PCA, enquanto a metodologia normal é composta dos 8 passos descritos no item 4.3.1 Detalhe do modelo base.

Apesar desta melhoria não ter sido mensurada, ela proporciona um ganho significativo para ambas às partes, ao Cliente devido o mesmo não ter mais o problema presente em seus produtos, com isso a disponibilidade do seu equipamento será maior; com relação à Empresa, o seu ganho será de não continuar pagamento garantias e, principalmente, por passar a ter a satisfação do seu Cliente, por ter resolvido o problema que estava importunando-o. 
Outro grande benefício desta melhoria refere-se ao registro das informações, em que todas as ações realizadas, todos os passos dados para a solução do problema, são registrados e mantidos no banco de dados, com o intuito de se ter um histórico, o qual também servirá de base no caso de reincidência deste problema, auxiliando no cálculo da pontuação em caso de reincidência.

Porém a grande vantagem é que todo o trabalho realizado pela equipe multifuncional, não será em vão, visto que caso este problema necessite ser trabalhado mais profundamente através da metodologia $8 \mathrm{D}$, todos os dados da forma Express é aproveitada pela forma 8D.

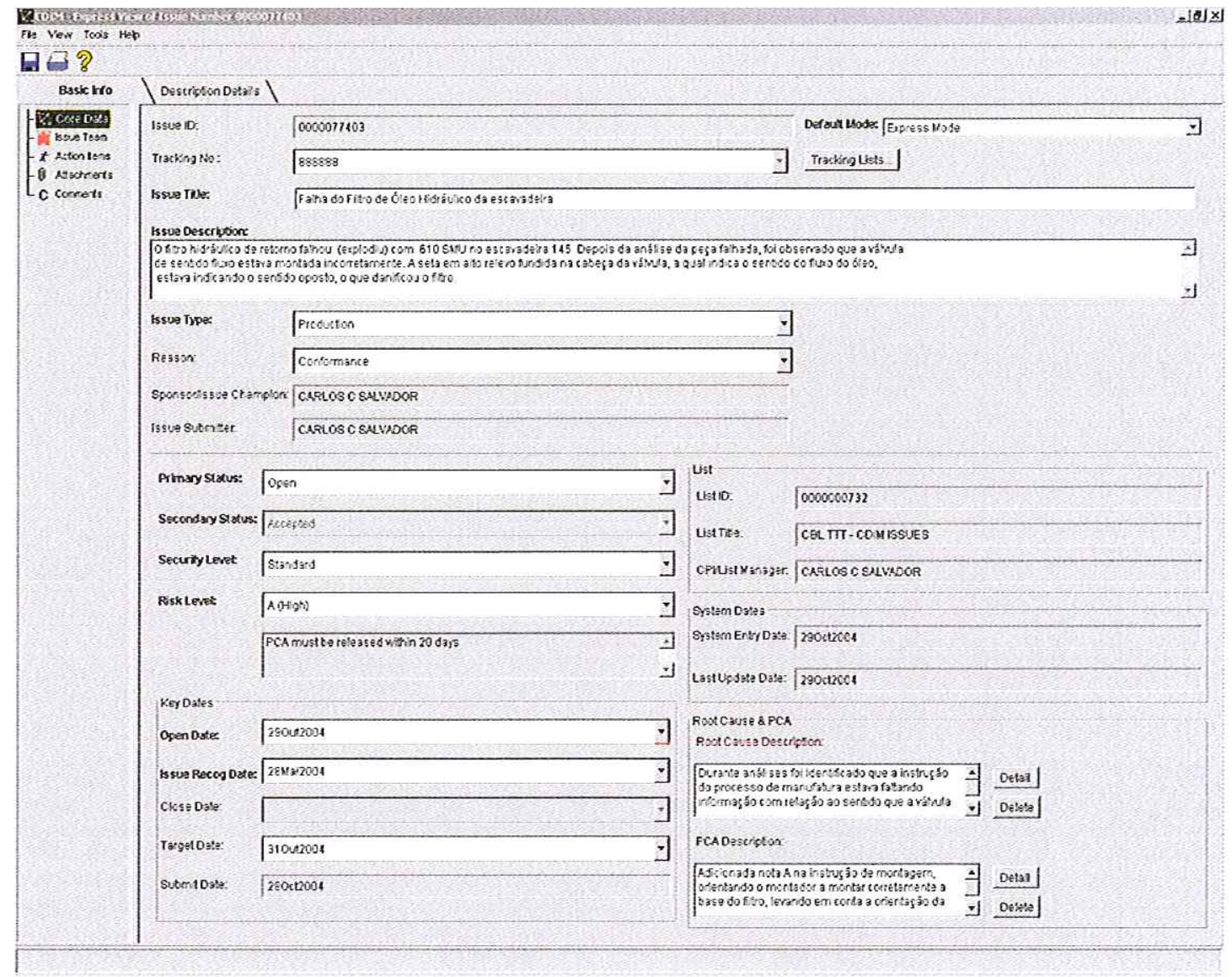

Figura 4-8 - Forma expressa 


\section{CAPITULO V}

\subsection{Conclusões finais}

O ciclo de desenvolvimento dos produtos tem diminuído constantemente, e o Cliente por sua vez tem exercido sua função de "majestade" e, com isso, tem exigido cada vez mais do produto, seja com relação à Confiabilidade, disponibilidade quando da compra, praticidade de uso, conforto ou mesmo simplesmente com relação à aparência. Isso tem forçado as Empresas a melhorarem seus processos de desenvolvimento de produtos cada vez mais, sair de sua área de conforto e buscar atender e até superar as expectativas e exigências do Cliente. Com isso, pode-se concluir que a filosofia do Ciclo de Qualidade ou Ciclo de Deming, mais conhecido como PDCA, não tem fim.

A manufatura virtual é uma ferramenta poderosa para acelerar a introdução de novos produtos e otimizar a produção, que pode determinar a capacidade da fábrica, maximizar a utilização dos recursos (humanos, equipamentos, máquinas, etc), auxiliar em todas as fases do desenvolvimento do projeto.

Porém, por melhor que seja a estratégia da Empresa, por mais disponíveis que softwares e equipamentos de última geração estejam, de nada adiantará se a Empresa não tiver o mais importante, as pessoas trabalhando em equipe, coesos, comprometidos e com um objetivo em comum. 
A interação e boa disposição dos profissionais de diferentes áreas, trabalhando em Equipe e a integração dessas áreas, em todas as etapas de desenvolvimento do produto, orientam o projeto de forma eficaz, fazendo que as dúvidas diminuam, as decisões sejam tomadas mais cedo e, como conseqüência, os tempos se encurtem, beneficiando diretamente a Empresa, levando-a ao tão desejado sucesso.

De maneira geral, conforme mostrado nos capítulos III e IV, conclui-se que os objetivos estabelecidos quando da elaboração deste trabalho foram atingidos, uma vez que as melhorias propostas contribuíram significativamente para a agilização na solução dos problemas de campo, seja no que diz respeito à contenção dos problemas até que uma solução definitiva seja implementada, ou no endereçamento da solução dos problemas com pontuação pequena através de Equipes multifuncionais, utilizando um sistema de registro de informações, compatível com o sistema de melhoria contínua (CPI), em uso pela Empresa.

Em relação as perguntas do item 1.2 Objetivos deste trabalho, foram respondidas da seguinte maneira:

- Qual a dificuldade de coletar determinados dados de campo ?

- Esta pergunta foi respondida nos itens 3.10 A dificuldade de se obter dados sobre os fatores operacionais, 3.10.1 Taxa de uso, 3.10.2 Tipo de aplicação e 3.10.3 Mau uso

- Como é realizada a comunicação entre o Cliente, Revenda e a Empresa?

- Esta pergunta foi respondida nos itens 3.6 Tarefas exigidas pelo fabricante, 3.7 Como é realizado o feedback do 
campo, 3.9 Dados de falhas coletados pela Revenda e 4.1.3 DSN - Dealer Solution Network

- Qual é a qualidade do processo de comunicação entre as 3 partes envolvidas?

- É muito bom, principalmente porque durante o período de garantia a Revenda é a responsável por realizar o reparo, o qual tem o custo dividido entre a Revenda e a Empresa, conforme foi descrito no item 3.1 Introdução e no 2.4 Confiabilidade e garantia.

- As oportunidades de melhoria, neste processo de comunicação, foram abordadas no item 3.9 Dados de falhas coletados pela Revenda.

- Como os dados de campo são tratados pela Empresa e quanto tempo leva para um problema ser solucionado?

- Esta pergunta foi respondida no item 4.2 Método base, 4.2.1 Quando uma solicitação pode ser encerrada e 4.3.1 Detalhe do modelo base 


\subsection{Recomendações para trabalhos futuros}

Algumas sugestões podem contribuir para a melhoria deste método, são elas:

- uma análise mais profunda junto à Revenda a fim de melhorar o processo de diagnóstico, correção e registro das falhas, além do feedback após a correção, a Empresa;

- Uma análise junto as equipes de CPPD a fim de avaliar a performance do mesmo, além da eficácia das ações propostas e implementadas pelo mesmo;

- uma pesquisa junto ao Cliente especifica a eficácia das ações proposta e aplicadas em seu produto, pela Empresa e Revenda;

- fazer uma pesquisa e análise a respeito do conhecimento teórico e prático dos mecânicos das Revendas, a fim de propor um programa de melhoria. 


\section{BIBLIOGRAFIA CONSULTADA}

Associação Brasileira de Normas Técnicas (2002). NBR 8927:2001 - Máquinas rodoviárias - Disponibilidade de máquina - Vocabulário.

Associação Brasileira de Normas Técnicas (2001). ABNT NBR ISO 9001:2000 - Sistemas de gestão da qualidade - Requisitos.

Abreu, Romeu Carlos L. de, (2001). Apostila de Gestão da Qualidade Total. Fundação Getulio Vargas - EPGE.

Agostinho, O. L. (2002). Sistemas de Manufatura. São Carlos, 2002.

Amaral, Daniel Capaldo \& Rozenfeld, Henrique (2001). Conceitos Gerais de Desenvolvimento de Produto. http://www.numa.org.br/conhecimentos/conhecimentos port/pag conhec/\#top.

Amaral, Claiton Emilio (2001). Sistematização da gestão de conhecimento técnico na geração de princípios de solução na fase de reprojeto conceitua de produtos. Dissertação de Mestrado Programa de Pós-Graduação em Engenharia de Produção na UFSC, Florianópolis.

Bérgamo Filho, Valentino (1997). Confiabilidade Básica e Prática. Ed Edgard Blücher Itda. São Paulo.

BS EN 61014:2003. British Standard, 2003. Programmes for reliability growth (Programas para crescimento da Confiabilidade). 
Cardoso, José Alberto Azevedo (2001). Eficiência de Sistema de Inspeção: Um Estudo de Caso no Setor Metalúrgico. Dissertação de Mestrado Programa de Pós-Graduação em Engenharia de Produção na UFRG, Porto Alegre.

Cascone, Nicésio Ronan (1992). Metodologia para análise e otimização da Confiabilidade, da mantenabilidade e da disponibilidade de um processo contínuo de produção. Tese de mestrado

Caterpillar inc (2003) Manual de Produção Caterpillar, Edição 34.

CATERPILLAR INC. (1997). New Product Introduction

Caterpillar (2003), CPI - Melhoria Constante do Produto. https: cpi.cat.com

Caterpilar (2003), Garantia Caterpillar - Produtos de Máquinas.

Clausing, Don (1994). Total quality development: a step-by-step guide to worldclass concurrent engineering.

Dallágnol Roberto (2001). Desenvolvimento de novos produtos através do gerenciamento simultâneo de projeto (GSP): Um estudo de caso na indústria de máquinas agrícolas. Dissertação de Mestrado Programa de Pós-Graduação em Administração na Faculdade Federal do Rio Grande do Sul, Porto Alegre.

Dias, Acires (2003). O ciclo de vida do produto e o processo de projeto. Revista Tec Hoje - Instituto de Educação Tecnológica - ietec. http//www.ietec.com.Br/ietec/techoje/meioambiente/2003/07/28_07_28

Dias, Acires (1999). Projeto para a Confiabilidade aplicada ao processo de implementação de uma rede de gás. Universidade Federal de Santa Catarina. 
Dummer, G. W. A., M. H. Tooley and R.C. Winton (1997 - 5 edicion) . An Elementary Guide to Reliability.

Ellis, Lindy (2003). Programmes for reliability growth updated to meet industry needs. IEC 61014, publicada em Julho de 2003 https://domino.iec.ch/webstore/webstore.nsf/artnum/030908

Falguera, Luis F. (2002). Confiabilidade. www.ortronics.com/brasil

Falcetta, Eduardo Fiorin (2000). Analise da Confiabilidade de Produtos baseada em Dados de Utilização de Garantia. Dissertação de Mestrado Programa de Pós-Graduação em Engenharia de Produção na UFRG, Porto Alegre.

Grinover, Ada Pellegrini; Benjamin, Antonio Herman de Vasconcellos e; Fink, Daniel Roberto; Filomeno, José Geraldo Brito; Watanabe, Kazuo; Nery Jr, Nelson \& Denari, Zelmo (1999). Código Brasileiro de Defesa do Consumidor, $6^{a}$. Edição.

Helman, Horácio \& Andery, Paulo Roberto Pereira (1995). Análise de falhas (Aplicação dos métodos de FMEA e FTA) - Belo Horizonte, MG: Fundação Christiano Ottoni, Escola de Engenharia da UFMG.

HSM Management 24, janeiro-fevereiro 2001.

http:www.qualytek.com.br/page10.html - QUALYTEK (Qualidade, Tecnologia e Sistemas Ltda - Distribuição de Weibull Conceitos Básicos).

http: www.sotreq.com.br/organizacao/organizacao.htm - SOTREQ

ISO 2394 - General principles on reliability for structure, second edition199806-01. 
Juran, J. M. (2001). A qualidade desde o projeto: Novos passos para o planejamento da qualidade em produtos e serviços. Editora Pioneira - São Paulo.

Landers, R. Richard (1963) Reliability and Product Assurance: A manual for Engineering and Management .

Las Casas, Alexandre Luzzi (1999) Qualidade total em serviços: conceitos, exercícios, casos práticos. Editora Atlas S. A.

Maintainability Standards \& Handbooks. Reliability Engineering, Department of Mechanic Engineering - University of Maryland. http://www.enre.umd.edu/ms\&h.htm.

Manual de Desenvolvimento de Componentes (2003). Pacote de Submissão \& Instruções (compilado do manual de PAPP do IQA e adaptado a AGCO do Brasil).

Marchand, Claire (2003). Programmes for reliability growth updated to meet industry needs.

O’ Connor, Patrick D. T. (1991). Prátical reliability engineering 3rd edição.

Paladini, Edson Pacheco (2000). Gestão da qualidade: teoria e prática. Editora Atlas.

Palady, Paul (IMAM 1997). FMEA: Análise dos Modos de Falha e Efeitos: prevendo e prevenindo problemas antes que ocorram.

Pallerosi, Carlos Amadeu (2000). Confiabilidade (A quarta dimensão da qualidade) - 1a. Edição. 
Pande, Peter S.; Neuman, Robert P. \& Cavanagh, Roland R. (2000). The six sigma way: how GE, Motorola, and other top companies are honing their performance

Pyzdek, Thomas (2003). Uma ferramenta em busca do defeito zero. Revista HSM Management , n. 38, pág 65-70, maio-junho.

RAVELLI, C.A. (2002). Análise da interoperabilidade de dados na implementação de um ambiente de Manufatura Virtual em Empresas do ramo automobilístico. Dissertação de Mestrado do Programa de Pós-Graduação em Engenharia Mecânica da Escola de Engenharia de São Carlos da Universidade de São Paulo, São Carlos.

Revista brasileira de gestão e desenvolvimento de produto, Ano 2, Número 2, Março $2002 . \quad$ http: www.ctc.ufsc.br/produto/Produto2/artigo2pt/artigo4/artigo4b.htm, Março.

Reliability Standards \& Handbooks. Reliability Engineering, Department of Mechanic Engineering - University of Maryland. http://www.enre.umd.edu/rs\&h.htm.

ReliaSoft Corporation (1992-1998). http:www.weibull.com/RelGrowthWeb/what_is_reliability_growth.htm.

Ribeiro, João Paulo \& Guimarães, Mário (1999). Conceitos da Confiabilidade.

Schaedler, Ismar Luis (2003). Gerenciamento Do Crescimento Da Confiabilidade: Um Estudo Aplicado No Setor De Máquinas Agrícolas. Dissertação de Mestrado Programa de Pós-Graduação em Engenharia de Produção na UFRG, Porto Alegre. 
Schneider, Ricardo Gazzana (2001). Metodologia para retroalimentação do ciclo de desenvolvimento de Produto com Dados de Confiabilidade Oriundos da Utilização do Produto em Campo. Dissertação de Mestrado Programa de PósGraduação em Engenharia de Produção na UFRG, Porto Alegre.

Silva Filho, Antonio Mendes (2003). Engenharia de Confiabilidade de Software. Revista Espaço Acadêmico - No 27- Agosto.

US MIL - STD - 1629A (1980). USA Military Standard. Procedures for performing a failure mode, effects and criticality analysis (Procedimento para desenvolver uma análise critica do modo e efeito da falha).

US MIL-HDBK-189. USA Military Standard. Reliability Growth Management.

US MIL-HDBK-H 108. USA Military Standard. Sampling Procedures and Tables for Life and Reliability Testing (Based on Exponential Distribution)

Vollertt Jr, João Rosaldon (1996). Confiabilidade e falhas de campo: Um estudo de caso para melhoria da Confiabilidade de um produto e reparo, através de um procedimento sistemático de coleta de dados. Dissertação de Mestrado Programa de Pós-Graduação em Engenharia de Produção da Universidade Federal de Santa Catarina, Florianópolis.

Werkema, Maria Cristina Catarino (1996). Avaliação da qualidade de medidas Belo Horizonte, MG: Fundação Christiano Ottoni, Escola de Engenharia da UFMG.

Zancul, Eduardo \& Hezenfeld, Henrique (1999) http://www.numa.org.br/conhecimentos/conhecimentos_port/pag_conhec/\#instr ucao - Engenharia Simultânea. 